DEVELOPMENT OF CANCER TARGETED NAMPT INHIBITORS

A Dissertation
Presented to
the Faculty of the Graduate School
at the University of Missouri-Columbia
In Partial Fulfillment
of the Requirements for the Degree
Doctor of Philosophy
KEIVAN SADRERAFI
Dr. Mark W. Lee Jr., Dissertation Supervisor
July 2015


The undersigned, appointed by the dean of the Graduate School, have examined the dissertation entitled

\section{DEVELOPMENT OF CANCER TARGETED NAMPT INHIBITORS}

presented by Keivan Sadrerafi, a candidate for the degree of doctor of philosophy, and hereby certify that, in their opinion, it is worthy of acceptance.

Professor Mark W. Lee Jr.

Professor Paul R. Sharp

Professor Justin R. Walensky

Professor Peter Pfeifer 
This dissertation is dedicated to my belowed parents

\author{
Enayatallah Sadrerafi \& Zohreh Amanat
}




\section{ACKNOWLEDGEMENTS}

First and foremost I would like to express my sincere appreciation to my advisor and mentor Dr. Mark W. Lee Jr. for his guidance, moral and financial support, and constructive criticism while allowing me to take charge of my own projects and be creative.

I would also would like to acknowledge Dr. Paul Sharp, Dr. Justin Walensky, and Dr. Peter Pfeifer for being patient with me, serving on my committee, and furthermore, taking the time to review this dissertation.

I also wish to thank the department of chemistry at University of Missouri for giving me the opportunity to pursue a higher education.

Additional gratitude is given to Mr. Jerry Brightwell, our pleasant and cheerful administrative assistant, for all his help and answering all of my questions in a timely manner. I would like to thank my dear friends and colleagues Dr. Constance Pfeifer, Dr. Lasantha Wickramasinghe, and Dr. Enrico Penk for their endless support and advice. I'm also thankful of Ellen Moore for being a great collaborator and for synthesizing some of the compounds used in the displacement binding studies.

Last but certainly not least, I would like to express my special appreciation to my family. My father, Enayatollah Sadrerafi, and my mother, Zohreh Amanat have constantly made sacrifices throughout the years so that I can have a better life. I thank them from the bottom of my heart for their love and continued motivation. And finally I would like to express my deepest gratitude to my loving, caring, and supportive fiancé Nasim Eftekhari. Your endless

encouragement and confidence when times get rough are much appreciated and duly noted. 


\section{TABLE OF CONTENTS}

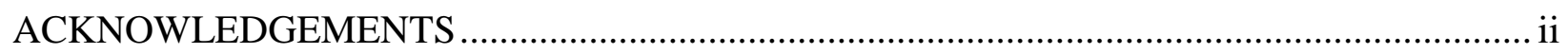

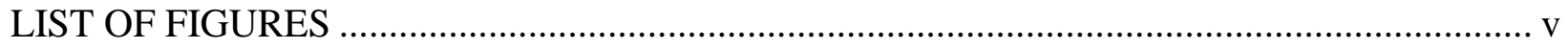

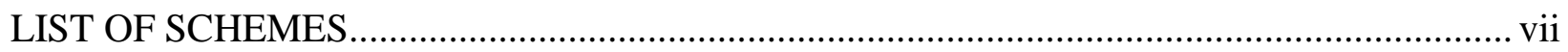

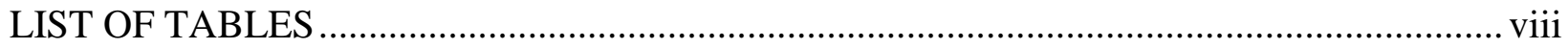

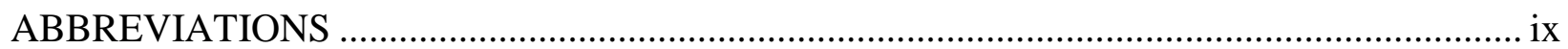

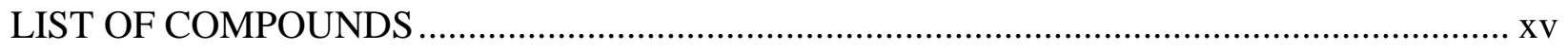

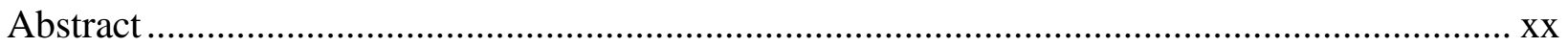

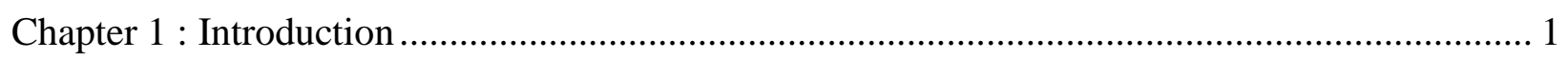

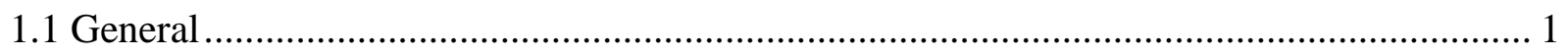

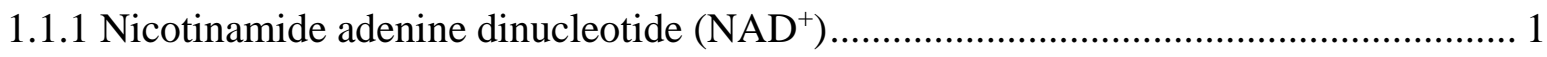

1.1.2 Nicotinamide phosphoribosyltransferase (Nampt) ......................................... 1

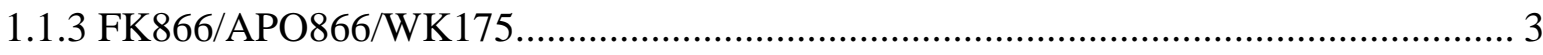

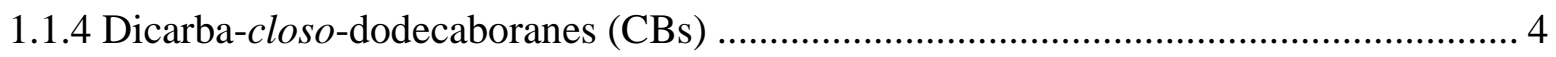

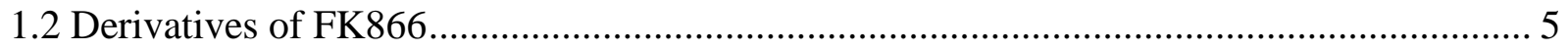

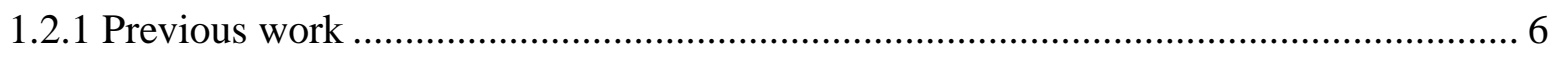

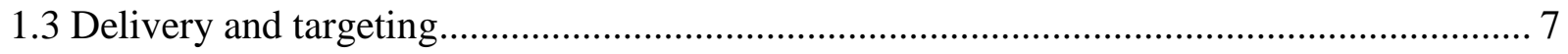

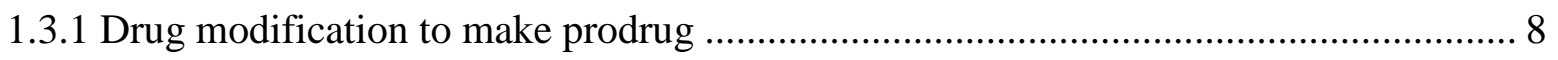

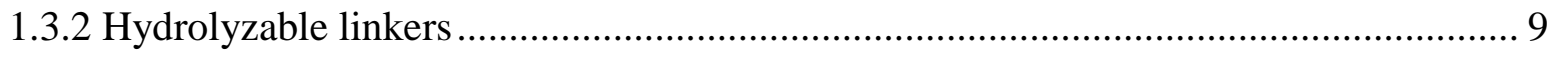

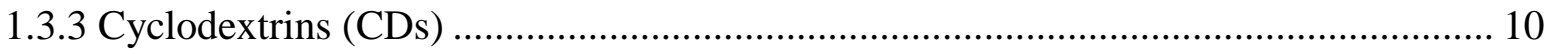

Chapter 2 : Improved Synthesis of MC4-PPEA and the Biological Evaluation of its

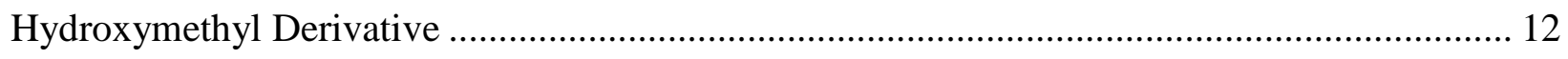

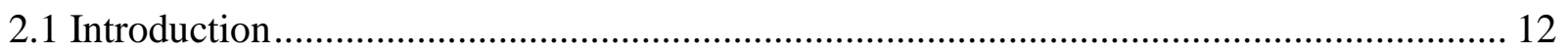




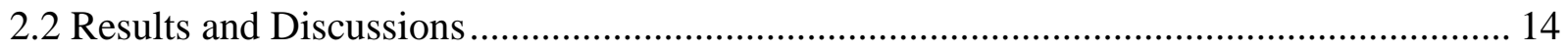

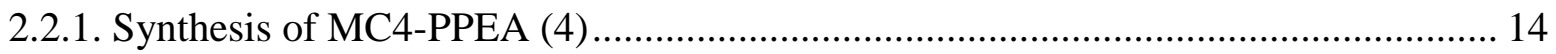

2.2.2 Synthesis of hydroxymethyl functionalized MC4-PPEA (11)................................... 17

2.2.3 Synthesis of other derivatives of MC4-PPEA ……................................................ 20

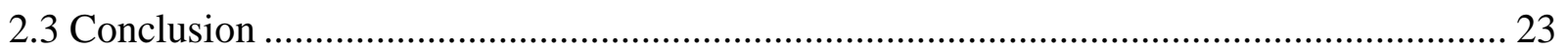

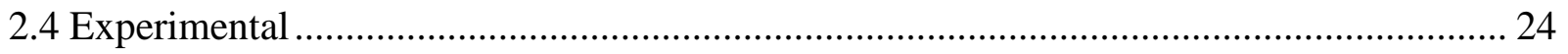

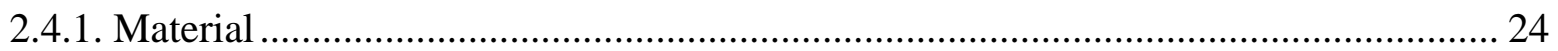

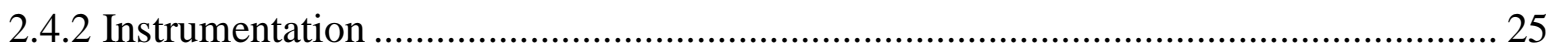

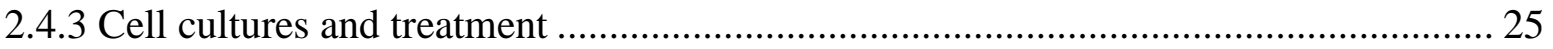

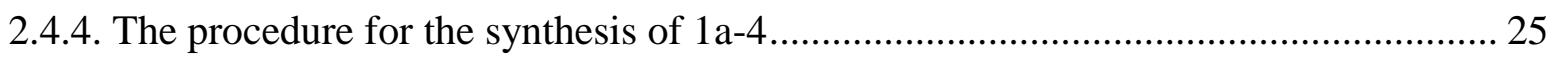

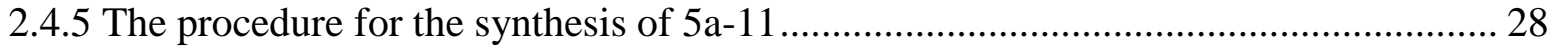

Chapter 3 : Prodrugs with Short Clickable Cleavable Linkers ...................................................... 37

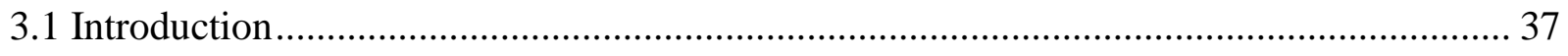

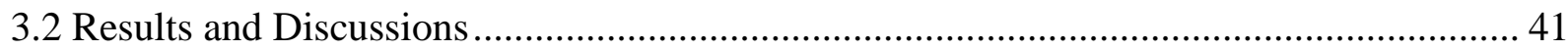

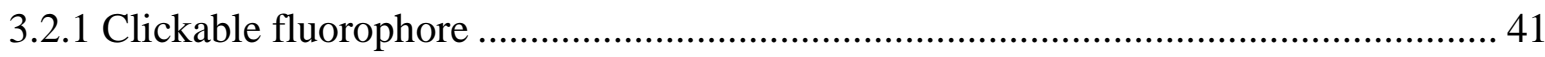

3.2.2 Hydrolysable linkers ........................................................................................ 42

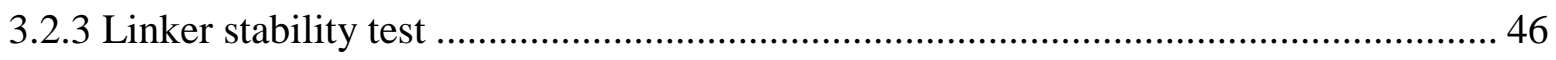

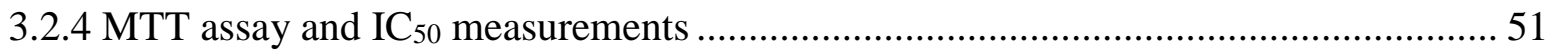

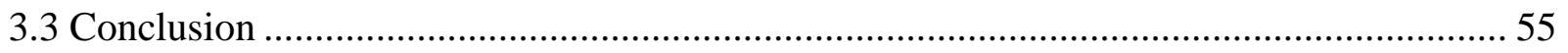

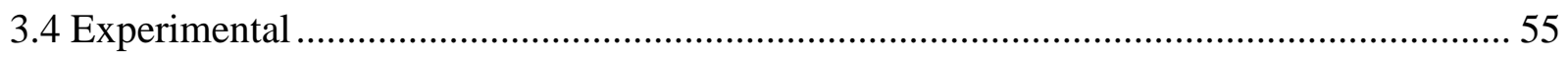

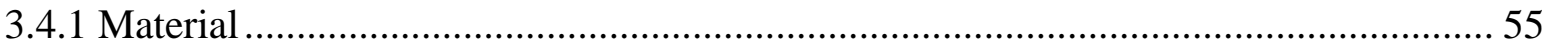

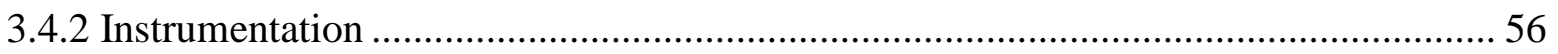

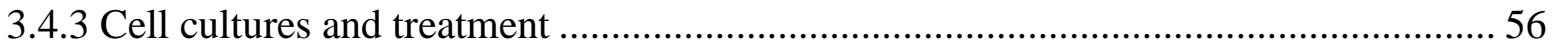


3.4.2 The procedure for the synthesis of clickable fluorophore

3.4.3 The procedure for the synthesis of prodrugs.

Chapter 4 : Association Constant of $\beta$-Cyclodextrin with Carboranes, Adamantane, and Their

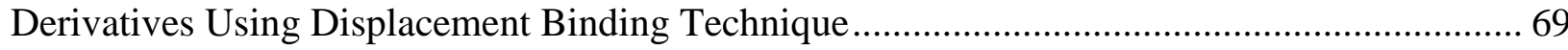

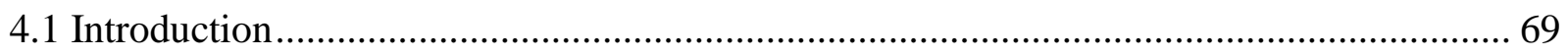

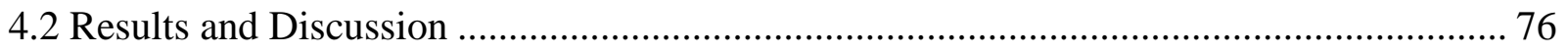

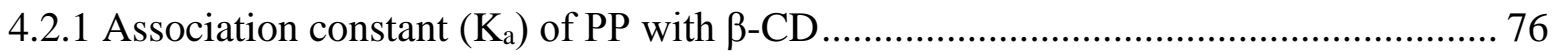

4.2.2 Association constant $\left(\mathrm{K}_{\mathrm{a}}{ }^{\prime}\right)$ of $\mathrm{CBs}$, adamantane, and their derivatives with $\beta$-CD..... 78

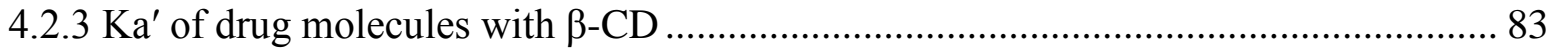

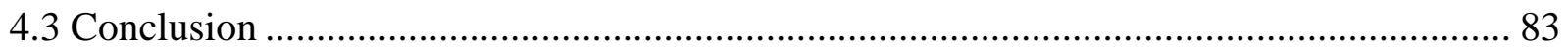

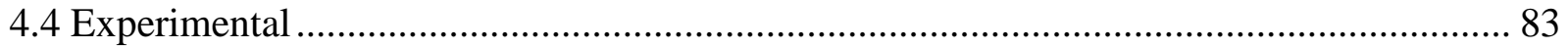

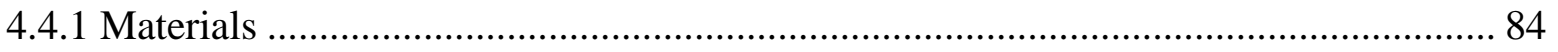

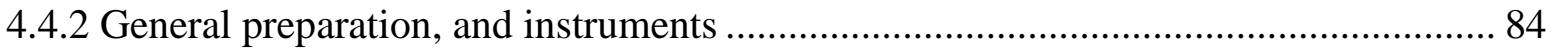

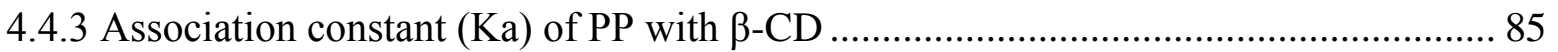

4.4.4 Association constant $\left(\mathrm{Ka}^{\prime}\right)$ of guest molecules with $\beta-\mathrm{CD}$................................. 86

4.4.5 Procedure for the synthesis of carborane derivatives ....................................... 92

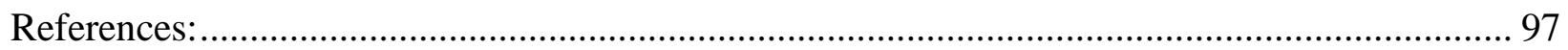

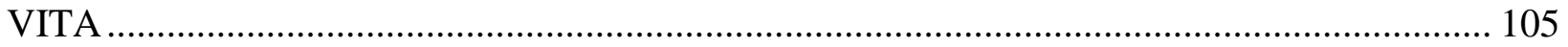

\section{LIST OF FIGURES}

Figure 1.1 - Crystal Structure of Nampt. ......................................................................... 2

Figure 1.2 - Components that make up the structure of FK866............................................ 4 


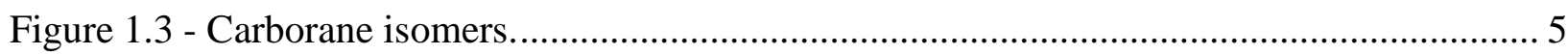

Figure 1.4 - FK866 derivatives synthesized previously by Lee group. ........................................ 7

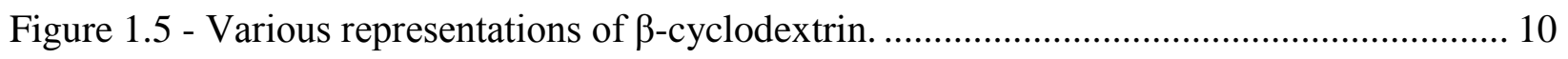

Figure 2.1 - Components that make up the structure of MC4-PPEA (4)..................................... 13

Figure 2.2 - Percent cell viability of human breast cancer cell lines: MCF7, T47D, and

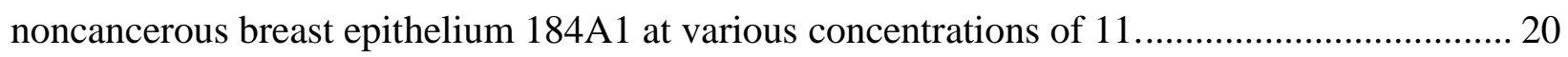

Figure 3.1 - Time dependent cleavage of 34 under various conditions........................................ 48

Figure 3.2 - Time dependent cleavage of 35 under various conditions. ...................................... 49

Figure 3.3 - Time dependent cleavage of 36 under various conditions...................................... 50

Figure 3.4 - Concentration dependent cell viability 11, 34, 35, and 36 against the T47D human

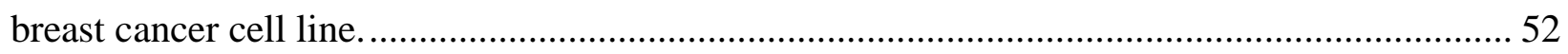

Figure 3.5 - Concentration dependent cell viability 11, 34, 35, and 36 against the MCF7 human

breast cancer cell line.

Figure 3.6 - Concentration dependent cell viability 11, 34, 35, and 36 against the 184A1 human

breast cancer cell line.

Figure 4.1 - Ball and stick structure of carborane isomers and adamantine................................ 70

Figure 4.2 - Sample absorption spectra of PP at various concentrations of 37e in presence of $\beta$ -

$\mathrm{CD}$ at $22{ }^{\circ} \mathrm{C} .[\mathrm{PP}]_{0}=3 \times 10^{-5} \mathrm{M}$ and $[\beta-\mathrm{CD}]_{0}=2 \times 10^{-4} \mathrm{M}$, in $\mathrm{Na}_{2} \mathrm{CO}_{3}$ buffer $\left(4 \times 10^{-3} \mathrm{M}, \mathrm{pH}\right.$

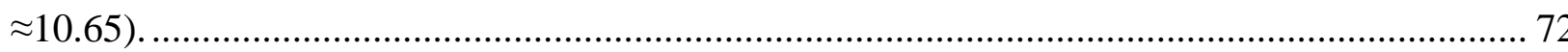

Figure 4.3 - Cyclodextrin functionalized polystyrene nanoparticles as possible delivery vehicles

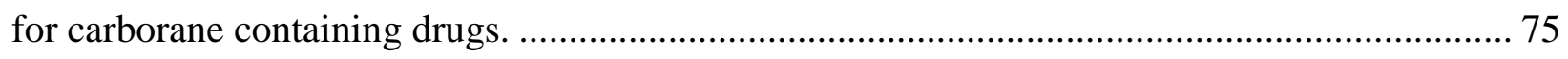

Figure 4.4 - Molecular structure of 4 (MC4-PPEA), and 12 (PhC4-PPEA) ................................. 76 
Figure 4.5 - Plot of $\left(\mathrm{A}_{0} / \mathrm{A}\right)-1$ against $\beta-\mathrm{CD}_{0}$ for PP: $\beta-\mathrm{CD}$ complex at $22{ }^{\circ} \mathrm{C}$. $[\mathrm{PP}]_{0}=3 \times 10^{-5} \mathrm{M}$ and $\beta-\mathrm{CD}=5 \times 10^{-5} \mathrm{M}-5 \times 10^{-4} \mathrm{M}$, in $\mathrm{Na}_{2} \mathrm{CO}_{3}$ buffer $\left(4 \times 10^{-3} \mathrm{M}, \mathrm{pH} \approx 10.65\right)$. The concentration of PP was determined by absorptivity at $552 \mathrm{~nm}$.

Figure 4.6 - Plot of $\left([\mathrm{PP}]_{0}-[\mathrm{PP}]\right) /\left([\beta-\mathrm{CD}]_{0}-[\mathrm{PP}]_{0}+[\mathrm{PP}]\right)$ against $[\mathrm{PP}]$ for $\beta-\mathrm{CD}: \mathrm{PP}$ complex at $22{ }^{\circ} \mathrm{C} .[\mathrm{PP}]_{0}=3 \times 10^{-5} \mathrm{M}$ and $\beta-\mathrm{CD}=5 \times 10^{-5} \mathrm{M}-6 \times 10^{-4} \mathrm{M}$, in $\mathrm{Na}_{2} \mathrm{CO}_{3}$ buffer $\left(4 \times 10^{-3} \mathrm{M}\right.$, $\mathrm{pH} \approx 10.65)$. The concentration of PP was determined by absorptivity at $552 \mathrm{~nm}$. 78

Figure 4.7 - Carborane derivatives: ortho- (37), meta- (38), and para-carborane (39).

Adamantine derivatives (40). 79

Figure 4.8 - Calibration curve for PP solution measured at $552 \mathrm{~nm}$. $[\mathrm{PP}]=3 \times 10^{-6} \mathrm{M}-3 \times 10^{-5}$

$\mathrm{M}$, in $\mathrm{Na}_{2} \mathrm{CO}_{3}$ buffer $\left(4 \times 10^{-3} \mathrm{M}, \mathrm{pH} \approx 10.65\right)$ at $22{ }^{\circ} \mathrm{C}$ 85

Figure 4.9 - Experimental data for 4, 4a, and 4c fitted to equation (5)..................................... 88

Figure 4.10 - Experimental data for 37, 38, 39, and 40 fitted to equation (5)............................. 89

Figure 4.11 - Experimental data for 37a, 38a, 37c, 38c, and 37e fitted to equation (5).............. 90

Figure 4.12 - Experimental data for 37b, 38b, 37d, 38d, and 37f fitted to equation (5).............. 91

Figure 4.13 - Experimental data for drugs 4, and 12 fitted to equation (5)............................... 92

\section{LIST OF SCHEMES}

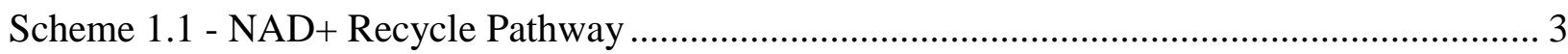

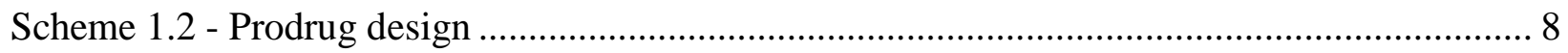

Scheme 2.1 - Previously reported synthetic pathway (a) and improved procedure (b) to

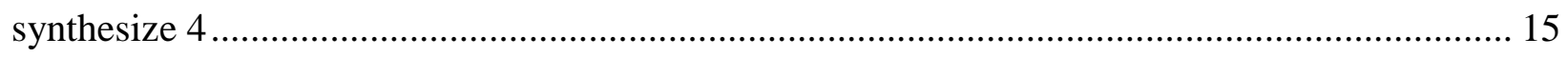

Scheme 2.2 - Metalation of $m$-carborane using $n$-butyllithium .................................................. 16 
Scheme 2.3 - Synthesis of hydroxymethyl functionalized MC4-PPEA (11) drug 18

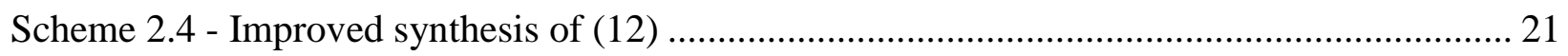

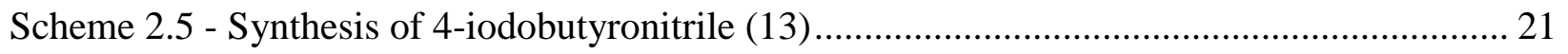

Scheme 2.6 - Synthesis of morpholine derivate (16) of the Nampt inhibitor ............................ 22

Scheme 2.7 - Synthesis of piperidine derivate (19) of the Nampt inhibitor ............................. 23

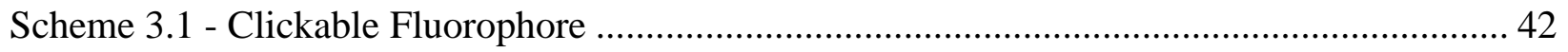

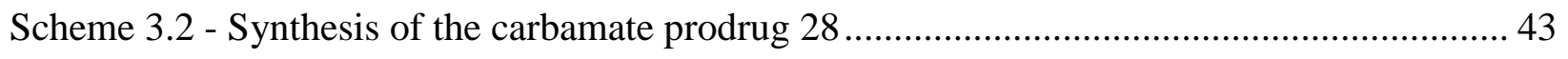

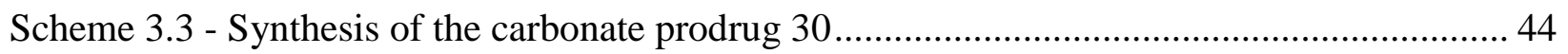

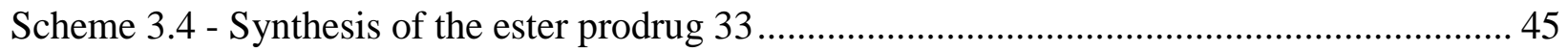

Scheme 3.5 - Prodrug linked to fluorophore through Click Chemistry ................................... 46

Scheme 4.1 - Schematic representation of the displacement technique using $\beta-C D, C B$,

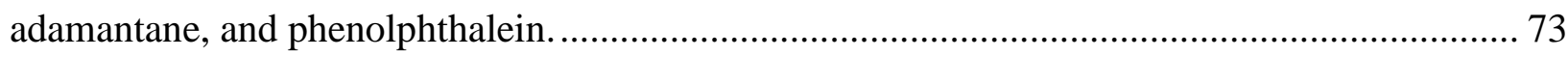

Scheme 4.2 - Synthesis of carborane derivatives (37a-f). The meta isomers (38a-d) were synthesized in a similar fashion. 74

\section{LIST OF TABLES}

Table 3.1 - Half-life $\left(\mathrm{t}_{1 / 2}\right)$ Stability of the Cleavable Linkers in PBS and Horse Serum at $37^{\circ} \mathrm{C} 51$ Table $3.2-\mathrm{IC}_{50}$ of Free-Drug (11) and Prodrugs (34-36) in Various Human Breast Cell Lines . 54 Table 4.1 - Association constant $\mathrm{K}_{\mathrm{a}}{ }^{\prime}\left(\mathrm{M}^{-1}\right)$ and the standard error of the estimate of carborane and adamantane derivatives with $\beta-\mathrm{CD}$ at $22^{\circ} \mathrm{C}$, in $4 \mathrm{mM} \mathrm{Na}_{2} \mathrm{CO}_{3}$ buffer $(\mathrm{pH} 10.65) \ldots \ldots \ldots \ldots \ldots . . . . . . . .79$ 


\begin{tabular}{|c|c|}
\hline & ABBREVIATIONS \\
\hline [G] & concentration of non-complexed guest molecule \\
\hline$[\mathrm{G}]_{0}$ & total concentration of guest molecule \\
\hline$[\mathrm{PP}]$ & concentration of non-complexed PP \\
\hline$[\mathrm{PP}]_{0}$ & total concentrations of PP \\
\hline$[\beta-C D]$ & concentration of non-complexed $\beta-\mathrm{CD}$ \\
\hline$[\beta-\mathrm{CD}]_{0}$ & total concentration of $\beta-\mathrm{CD}$ \\
\hline $1 \mathrm{Ad}-\mathrm{CH}_{2} \mathrm{OH}$ & 1-adamantanemethanol \\
\hline $1 \mathrm{Ad}-\mathrm{OH}$ & 1-adamantanol \\
\hline A & peak absorbance of PP in presence of $\beta-C D$ \\
\hline $\mathrm{A}_{0}$ & peak absorbance of PP in absence of $\beta-C D$ \\
\hline $\mathrm{AcOH}$ & acetic acid \\
\hline Ad & Adamantane \\
\hline $\mathrm{ADC}$ & antibody drug conjugates \\
\hline ADME & absorption, distribution, metabolism, and excretion \\
\hline AEC2-PPEA & trans- $N$-(3'-(1"'-adamantyl)-2'-propyn-1'-yl)-3-(3"'-pyridyl)acrylamide \\
\hline $\mathrm{Ag}_{2} \mathrm{O}$ & silver(I) oxide \\
\hline ATP & adenosine triphosphate \\
\hline $\mathrm{B}(\mathrm{OMe})_{3}$ & trimethyl borate \\
\hline BNCT & boron neutron capture therapy \\
\hline BOP & $\begin{array}{l}\text { benzotriazole-1-yl-oxy-tris-(dimethylamino)-phosphonium } \\
\text { hexafluorophosphate }\end{array}$ \\
\hline C4-PPEA & trans- $N$-butyl-3-(3'-pyridyl)acrylamide \\
\hline
\end{tabular}




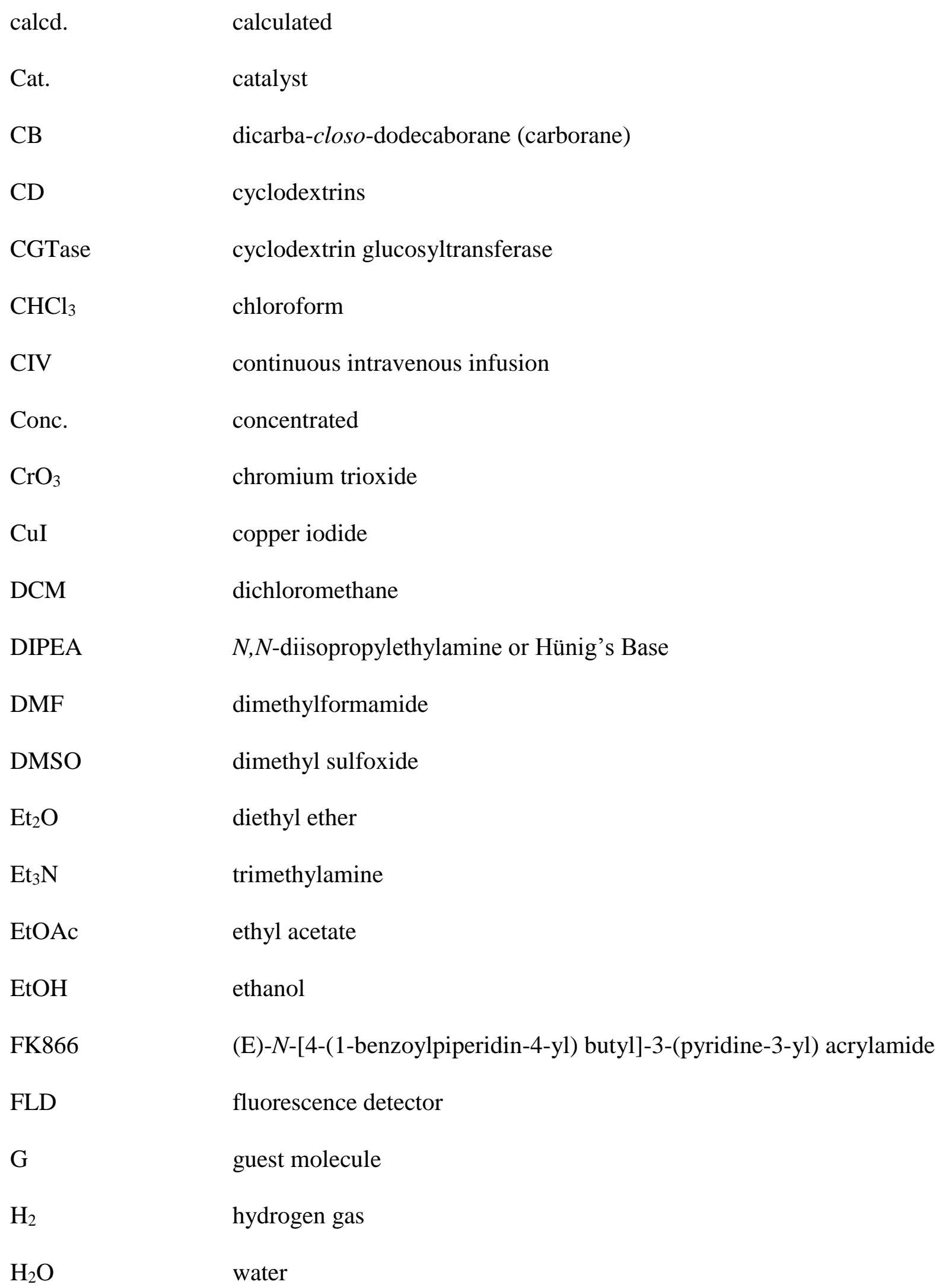




\begin{tabular}{|c|c|}
\hline $\mathrm{H}_{2} \mathrm{O}_{2}$ & hydrogen peroxide \\
\hline $\mathrm{H}_{2} \mathrm{SO}_{4}$ & sulfuric acid \\
\hline $\mathrm{HCl}$ & hydrochloric acid \\
\hline hm-MC4-PPEA & $\begin{array}{l}\text { 1-(hydroxymethyl)-7-(4'-(trans-3"-(3"'-pyridyl)acrylamido)butyl)-m- } \\
\text { carborane }\end{array}$ \\
\hline HMPA & hexamethylphosphoramide \\
\hline HPLC & high performance liquid chromatography \\
\hline $\mathrm{hr}$ & hour \\
\hline $\mathrm{IC}_{50}$ & half-maximal inhibitory concentration \\
\hline ITC & isothermal titration calorimetry \\
\hline $\mathrm{K}_{2} \mathrm{CO}_{3}$ & potassium carbonate \\
\hline $\mathrm{K}_{\mathrm{a}}$ & association constant of phenolphthalein with $\beta-\mathrm{CD}$ \\
\hline $\mathrm{K}_{\mathrm{a}}^{\prime}$ & association constant of guest molecules with $\beta-\mathrm{CD}$ \\
\hline KI & potassium iodide \\
\hline $\mathrm{LiAlH}_{4}$ & lithium aluminum hydride \\
\hline MC4-PPEA & $\begin{array}{l}\text { 1-(4'-(trans-3"-(3"'-pyridyl)acrylamido)butyl)-1,7-dicarba-closo- } \\
\text { dodecaborane }\end{array}$ \\
\hline$m$-CB & 1,7-dicarba-closo-dodecaborane (meta-carborane) \\
\hline $\mathrm{MeOH}$ & methanol \\
\hline $\mathrm{MgSO}_{4}$ & magnesium sulfate \\
\hline MS & mass spectrometry \\
\hline MTD & maximum tolerated dose \\
\hline MTT assay & microculture tetrazolium assay \\
\hline
\end{tabular}




\begin{tabular}{|c|c|}
\hline $\mathrm{Na}_{2} \mathrm{CO}_{3}$ & sodium carbonate \\
\hline $\mathrm{Na}_{2} \mathrm{~S}_{2} \mathrm{O}_{3}$ & sodium thiosulfate \\
\hline $\mathrm{Na}_{2} \mathrm{SO}_{4}$ & sodium sulfate \\
\hline $\mathrm{NAD}^{+}$ & nicotinamide adenine dinucleotide \\
\hline $\mathrm{NaH}$ & sodium hydride \\
\hline $\mathrm{NaI}$ & sodium iodide \\
\hline Nam & nicotinamide \\
\hline Nampt & nicotinamide phosphoribosyltransferase \\
\hline $\mathrm{NaN}_{3}$ & sodium azide \\
\hline$n$-BuLi & $n$-butyllithium \\
\hline neg. & negative \\
\hline NMN & nicotinamide mononucleotide \\
\hline Nmnat & nicotinamide mononucleotide adenylyltransferase \\
\hline NMR & nuclear magnetic resonance \\
\hline OC4-PPEA & $\begin{array}{l}\text { 1-(4'-(trans-3"'-(3"'-pyridyl)acrylamido)butyl)-1,2-dicarba-closo- } \\
\text { dodecaborane }\end{array}$ \\
\hline$o-\mathrm{CB}$ & 1,2-dicarba-closo-dodecaborane (ortho-carborane) \\
\hline $\mathrm{P}_{2} \mathrm{O}_{5}$ & phosphorus pentoxide \\
\hline PAC & trans-3-(3'-pyridyl)acryloyl chloride \\
\hline PARP & poly (ADP-ribose) polymerase \\
\hline PBEF & pre-B-cell colony-enhancing factor \\
\hline PBS & Phosphate buffered saline \\
\hline
\end{tabular}




\begin{tabular}{|c|c|}
\hline PC4-PPEA & $\begin{array}{l}\text { 1-(4'-(trans-3"-(3"'-pyridyl)acrylamido)butyl)-1,12-dicarba-closo- } \\
\text { dodecaborane }\end{array}$ \\
\hline$p$-CB & 1,12-dicarba-closo-dodecaborane (para-carborane) \\
\hline $\mathrm{Pd} / \mathrm{C}$ & palladium on activated carbon \\
\hline PDC & probody drug conjugate \\
\hline PEG & polyethylene glycol \\
\hline PFA & paraformaldehyde \\
\hline PhC4-PPEA & trans- $N$-(4'-phenylbutyl)-3-(3"'-pyridyl)acrylamide \\
\hline Phe & phenylalanine \\
\hline PMDETA & $N, N, N^{\prime}, N^{\prime}, N^{\prime \prime}$-pentamethyldiethylenetriamine \\
\hline Pos. & positive \\
\hline $\mathrm{PP}$ & phenolphthalein \\
\hline $\mathrm{PPh}_{3}$ & triphenylphosphine \\
\hline PRPP & phosphoribosyl pyrophosphate \\
\hline quant. & Quantitative \\
\hline r.t. & room temperature \\
\hline SIRT & sirtuin \\
\hline $\mathrm{SOCl}_{2}$ & thionyl chloride \\
\hline $\mathrm{t}_{1 / 2}$ & half-life \\
\hline TBAF & tetra- $n$-butylammonium fluoride \\
\hline TGA & thermogravimetric analysis \\
\hline THF & tetrahydrofuran \\
\hline $\mathrm{TrCl}$ & triphenylmethyl chloride \\
\hline
\end{tabular}




$\begin{array}{ll}\text { TsCl } & p \text {-toluenesulfonyl chloride } \\ \text { Tyr } & \text { tryptophan } \\ \text { UV-Vis } & \text { ultraviolet-visible spectroscopy } \\ \alpha-\mathrm{CD} & \text { alpha-cyclodextrin } \\ \beta-\mathrm{CD} & \text { beta-cyclodextrin } \\ \gamma-\mathrm{CD} & \text { gamma-cyclodextrin }\end{array}$




\section{LIST OF COMPOUNDS}

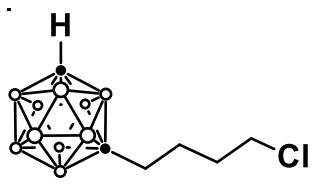

$1 a$

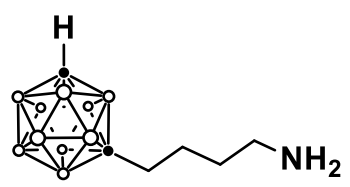

3

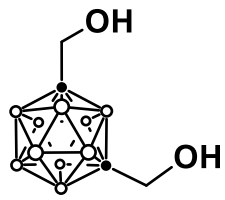

5 b

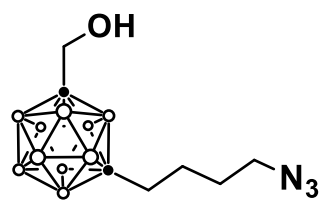

9

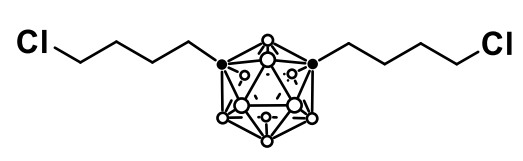

$1 b$
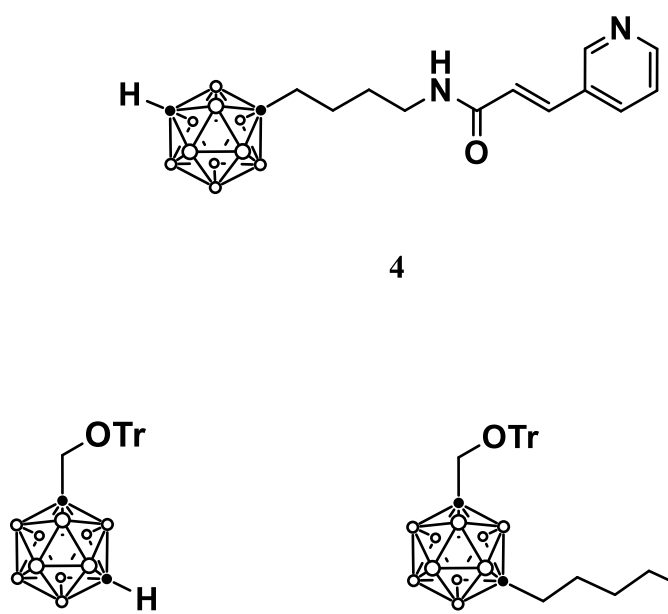

6

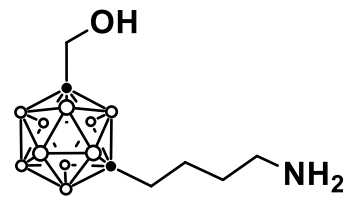

10
4

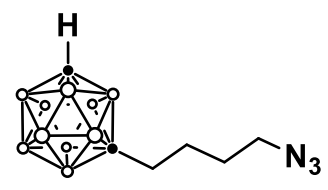

2

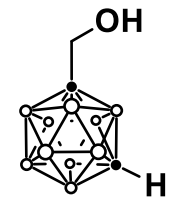

$5 a$

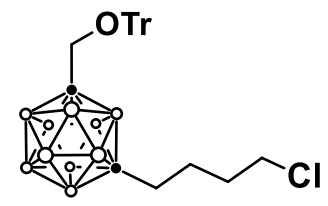

7

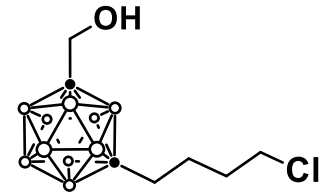

8

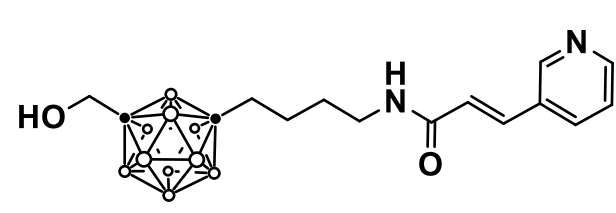

11 
<smiles>O=C(/C=C/c1cccnc1)NCCCCc1ccccc1</smiles>

12<smiles>N#CCCCI</smiles>

13

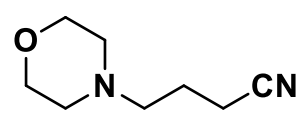

14<smiles>NCCCCN1CCOCC1</smiles>

15<smiles>NCCCCN1CCCCC1</smiles>

18<smiles>O=C(/C=C/c1cccnc1)NCCCCN1CCOCC1</smiles>

16<smiles>O=C(/C=C/c1cccnc1)NCCCCN1CCCCC1</smiles>

19<smiles>N#CCCCN1CCCCC1</smiles>

17<smiles>C#CCOCCOCCOCCOCCN</smiles><smiles>OCCOCC[SeH3-]</smiles>

24a

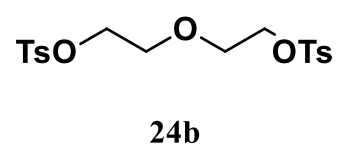

24b<smiles>NCCOCCN</smiles>

26 


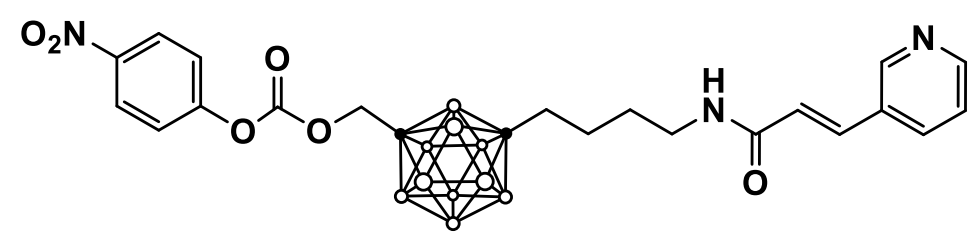

27

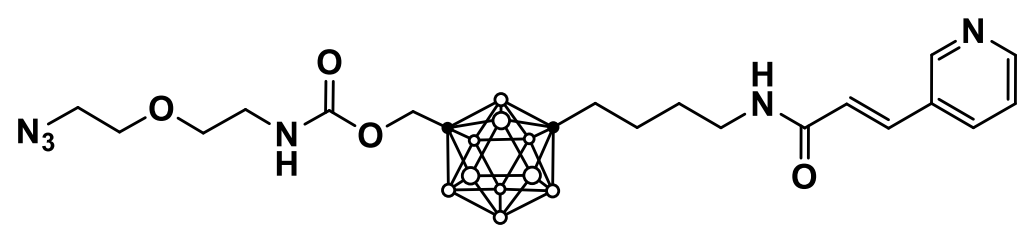

28

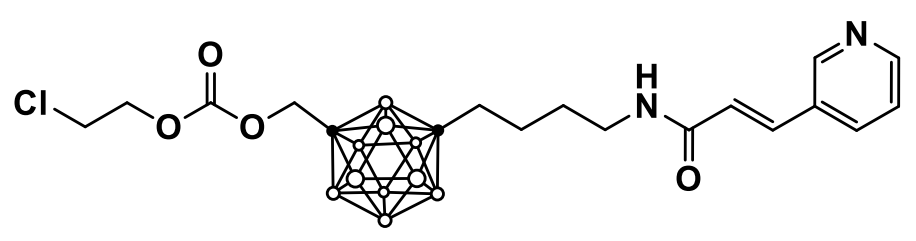

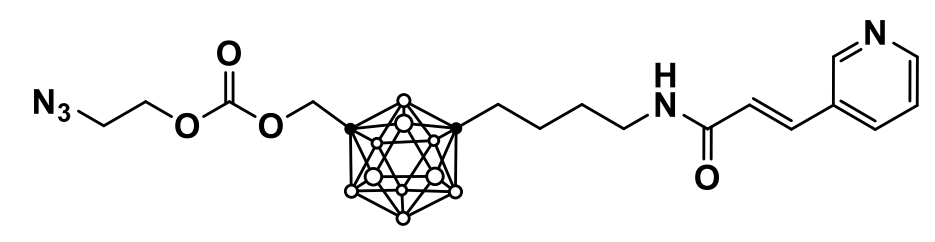

HO 31<smiles>[N]CCOCC(=O)Cl</smiles>

32

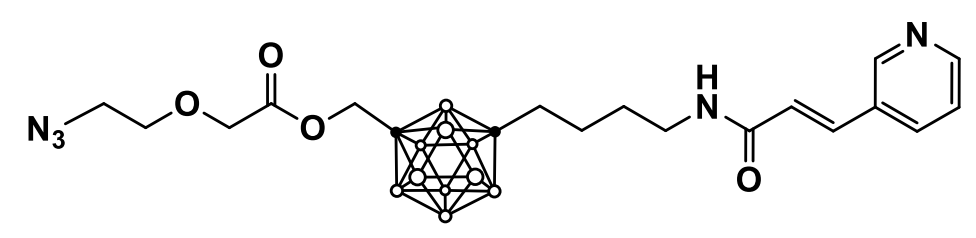


<smiles>CN(C)c1cccc2c(S(=O)(=O)NCCOCCOCc3cn(CCOCCNC(=O)OCc4ccccc4COCc4ccccc4)nn3)cccc12</smiles>

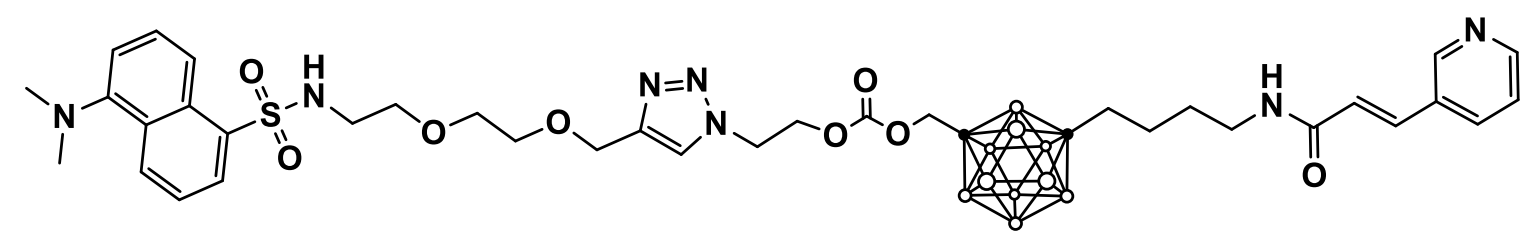<smiles>CN(C)c1cccc2c(S(=O)(=O)NCCOCCOCc3cn(CCOCC(=O)OCc4ccccc4CCCCNC(=O)/C=C/c4cccnc4)nn3)cccc12</smiles>
36

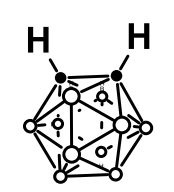

37

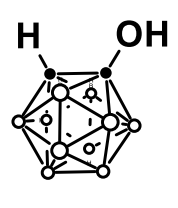

$37 \mathbf{a}$

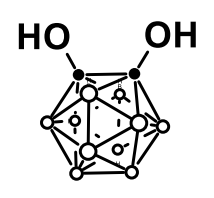

37b
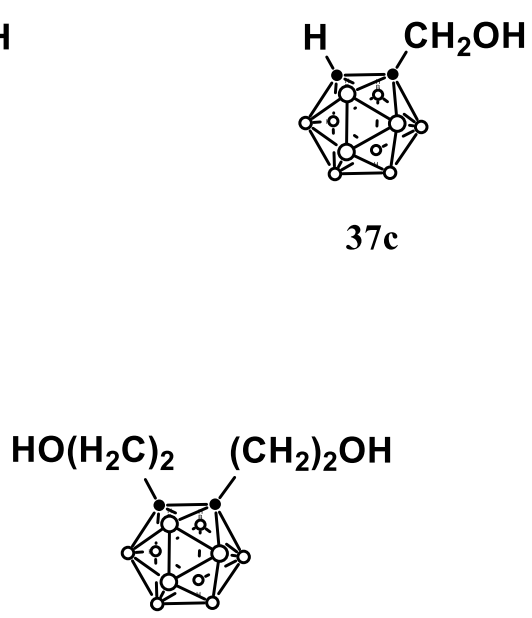

$37 f$ 


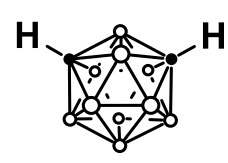

38

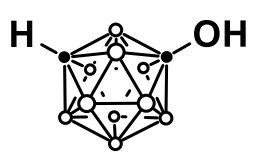

$38 a$

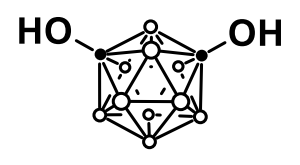

38b

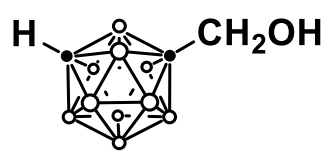

$38 c$

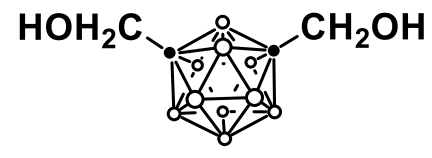

38d

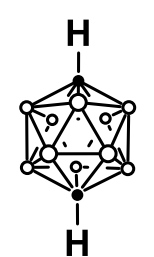

39

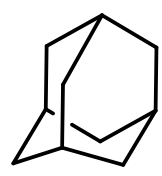

40

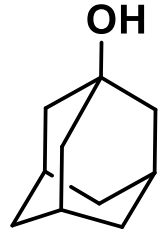

$40 a$

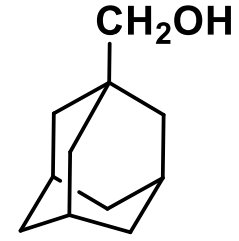

40c 


\title{
DEVELOPMENT OF CANCER TARGETED NAMPT INHIBITORS
}

\author{
Keivan Sadrerafi \\ Dr. Mark W. Lee Jr., Dissertation Supervisor
}

Abstract

The purpose of this research is the discovery of a highly potent pharmaceutical that can selectively cause apoptosis in various cancer cells. To utilize hydrophobic properties of carboranes, 1,7-dicarba-closo-dodecaborane $(m-\mathrm{CB})$ has been selected as a template to synthesize new targeted antitumor agent. These drugs selectively bind to nicotinamide phosphoribosyltransferase (Nampt), preventing cancer cells from replenishing nicotinamide adenine dinucleotide $\left(\mathrm{NAD}^{+}\right)$through their recycle pathway, leading to apoptosis.

Previously, our group reported a family of potent small molecule inhibitors of Nampt. Herein an improved, gram-scale synthesis of our most potent agent: 1-(4'-(trans-3' '-(3','pyridyl) acrylamide)butyl)-1,7-dicarba-closo-dodecaborane (MC4-PPEA), as well as several other derivatives is reported. Additionally, the carborane moiety of the molecule has been modified with a hydroxymethyl functional group to allow for its covalent attachment to targeted prodrugs. This new molecule exhibits nanomolar potencies against human breast cancer cell lines in vitro.

In this dissertation, several linker models capable of reacting with drug molecules containing primary alcohols are also proposed. These molecules are covalently linked through different hydrolytically or enzymatically cleavable moieties, each bearing an azide at its distal 
end. Using click chemistry, these prodrugs can be readily attached to protein or peptide targeting vectors, imaging agents, or other therapeutic delivery vehicles in high yield.

The association constants $\left(\mathrm{K}_{\mathrm{a}}{ }^{\prime}\right)$ of unsubstituted $o-, m$-, and $p$-carborane, adamantane, and their derivatives with $\beta$-cyclodextrin $(\beta-C D)$ are reported for the first time using displacement binding in an aqueous solution. The limitations of this technique are also explored. Although hydrophobicity plays a major role in the association with $\beta-\mathrm{CD}$, unsubstituted $o$-carborane which is the least hydrophobic carborane derivative, exhibits the highest $\mathrm{K}_{\mathrm{a}}{ }^{\prime}$ of $2690 \mathrm{M}^{-1}$. The $\mathrm{K}_{\mathrm{a}}{ }^{\prime}$ values for the $m$-, and $p$-carborane isomers decrease with decreasing dipole moment $\left(1830 \mathrm{M}^{-1}\right.$ and $1560 \mathrm{M}^{-1}$ respectively). Adamantane exhibits a $\mathrm{K}_{\mathrm{a}}{ }^{\prime}$ value lower than each of the three carborane isomers at $1410 \mathrm{M}^{-1}$. Our carborane containing drug MC4-PPEA exhibited $\mathrm{K}_{\mathrm{a}}{ }^{\prime}$ of 2606 $\mathrm{M}^{-1}$ which could lead to the possible use of $\beta$-CDs as delivery vehicles for our CB containing drugs. 


\section{Chapter 1 : Introduction}

\subsection{General}

Today, cancer treatment involves surgery, radiation, chemotherapy, or a combination of the three. Discovery of a highly potent pharmaceutical that can selectively and efficiently target various cancer cells and cause apoptosis with minimal cytotoxicity to healthy cells is of high interest. Recently, polyhedral heteroboranes, specifically dicarba-closo-dodecaboranes

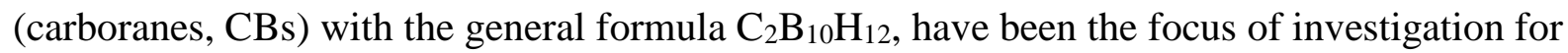
their use as pharmaceutical building blocks. Carborane moieties have hydrophobic properties as well as a special type of proton-hydride hydrogen bond (dihydrogen bonds), thus they are able to interact with biomolecules. ${ }^{1}$

\subsubsection{Nicotinamide adenine dinucleotide $\left(\mathrm{NAD}^{+}\right)$}

Nicotinamide adenine dinucleotide $\left(\mathrm{NAD}^{+}\right)$is a coenzyme found in all living cells. It is a vital cofactor that is used throughout cellular respiration, glycolysis, the citric acid cycle, cell signaling, transcription regulation, post-translation protein modification, and reactions linking cellular respiration with oxidative phosphorylation. It plays the role of currency in terms of energy and signaling within cells. This coenzyme plays a crucial role in cell survival, so not only it is synthesized de novo using tryptophan, aspartic acid, nicotinic acid, and quinolinic acid, it is also recycled within cells.

\subsubsection{Nicotinamide phosphoribosyltransferase (Nampt)}


Nampt (Figure 1.1) is an enzyme that has been mentioned in publications using several other names including pre-B-cell colony-enhancing factor $(\mathrm{PBEF})^{2}$ as well as visfatin ${ }^{3}$ which was believed to be an insulin-mimetic adipocytokine. ${ }^{4,5}$ The later was dismissed and the paper was retracted due to lack of reproducibility of data. ${ }^{6}$ Finally in 2002, it was confirmed that PBEF was an enzyme that catalyzed the reaction between nicotinamide (Nam) and phosphoribosyl pyrophosphate (PRPP) to produce nicotinamide mononucleotide (NMN) and pyrophosphate (Scheme 1.1). ${ }^{7-11}$ The name of this enzyme was then designated as Nampt. ${ }^{12}$ The conversion of $\mathrm{NMN}$ to $\mathrm{NAD}^{+}$is catalyzed with another enzyme called nicotinamide mononucleotide adenylyltransferase (Nmnat) which is approximately 46-fold more active than Nampt, making Nampt the rate-limiting step of the recycle pathway., ${ }^{9}$

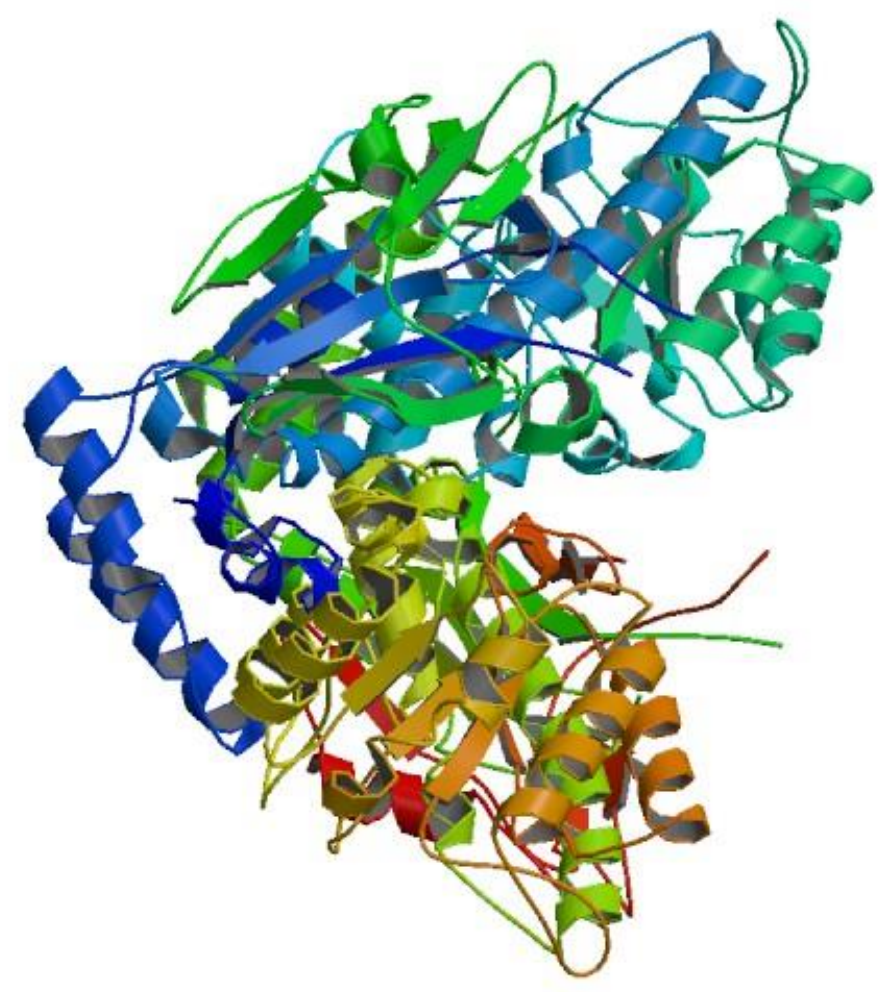

Figure 1.1 - Crystal Structure of Nampt. ${ }^{13}$ 
Scheme 1.1 - NAD ${ }^{+}$Recycle Pathway

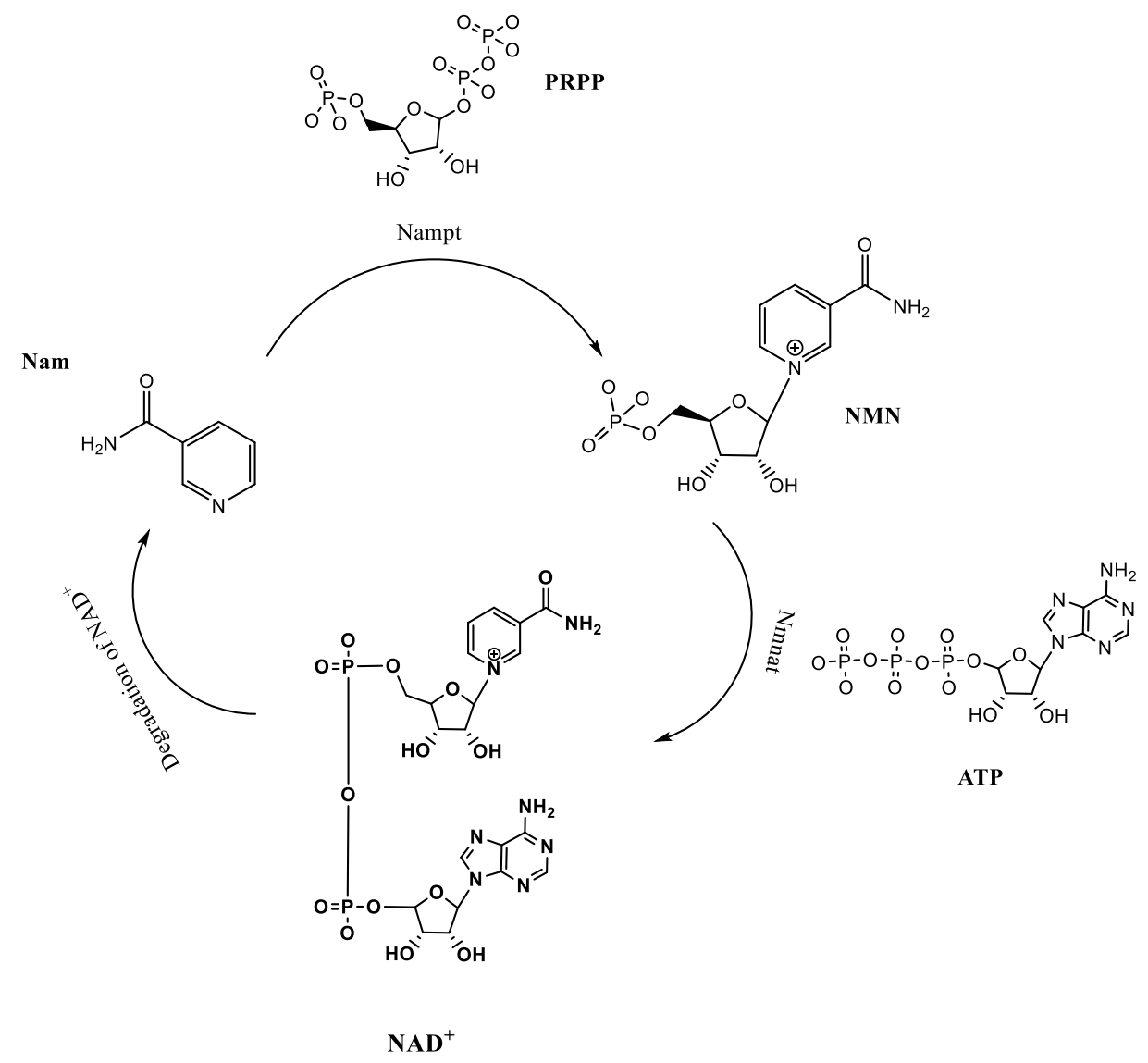

\subsubsection{FK866/APO866/WK175}

The compound (E)-N-[4-(1-benzoylpiperidin-4-yl) butyl]-3-(pyridine-3-yl) acrylamide (FK866) also known as APO866 and WK175 is currently being investigated in several Phase I and I/II clinical trials (Figure 1.2). ${ }^{14,15}$ It has been demonstrated that FK866 induces delayed apoptosis in cells by inhibiting Nampt activity resulting in gradual depletion of $\mathrm{NAD}^{+} .{ }^{14}$ Hyperactivity of cancer cells results in greater turnover of $\mathrm{NAD}^{+}$, therefore the depletion of this coenzyme would lead to apoptosis of these cells somewhat selectively. ${ }^{16}$ Activity of FK866 is cell-line dependent and has exhibited antiproliferative activity with half-maximal inhibitory 
concentration $\left(\mathrm{IC}_{50}\right)$ of $1 \mathrm{nM}$ in human ovarian cancer cell line A2780. ${ }^{17}$ Crystal structure of Nampt and its complex with NMN or FK866 has been reported by several groups. ${ }^{13,18,19}$ This helps to identify the enzyme active site as well as determining the properties of the moiety that interacts with the active site. The residues on Nampt that participate in binding of inhibitors have been identified to be Tyr18', and Phe193 which are involved in pi-stacking with the pyridine ring on FK866..$^{20,21}$

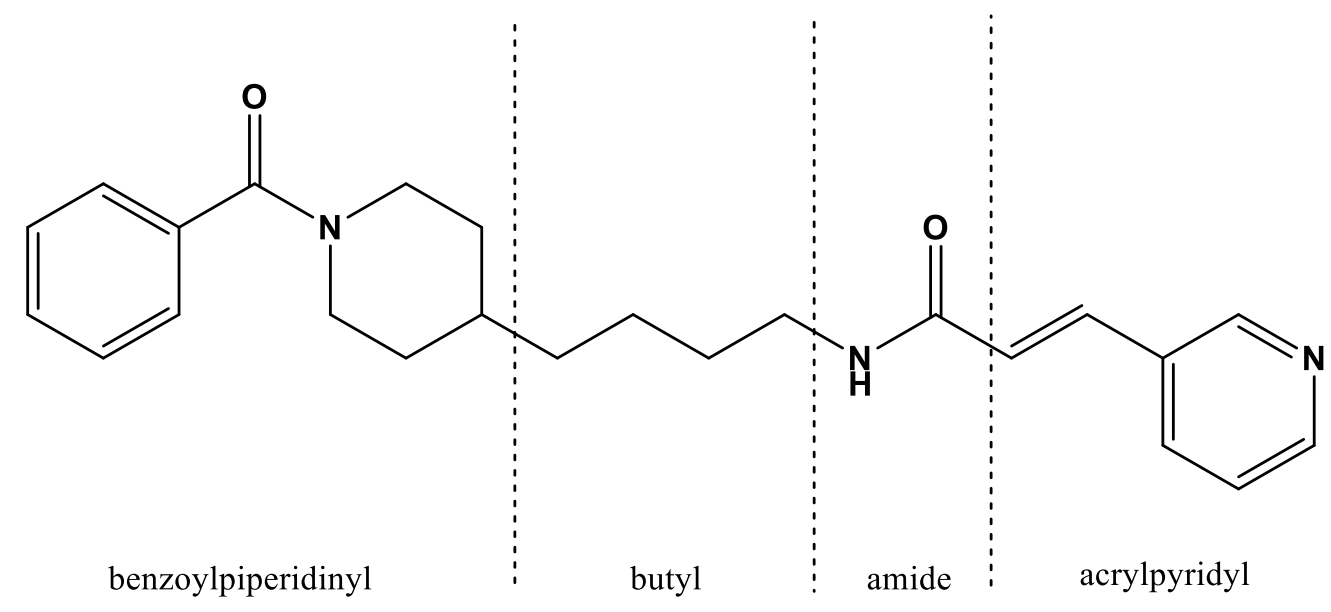

Figure 1.2 - Components that make up the structure of FK866.

\subsubsection{Dicarba-closo-dodecaboranes (CBs)}

Dicarba-closo-dodecaboranes are icosahedral cage structured polyhedral heteroboranes made of $10 \mathrm{~B}-\mathrm{H}$ and $2 \mathrm{C}-\mathrm{H}$ vertices. The robust three-dimensional structure of $\mathrm{CBs}$ have hexacoordinate boron and carbon atoms which results in an overall electron deficient cage. The B-H bonds are hydridic and have the ability to interact with biomolecules through unique protonhydride type hydrogen bonding. ${ }^{1}$ The cage also experiences longer than typical C-C, C-B, and 
B-B bond lengths. ${ }^{22} \mathrm{CBs}$ are extremely hydrophobic, and are structurally and thermally stable. They are also very stable at various $\mathrm{pH}$, especially extremely acidic conditions. Depending on the position of the carbon atoms relative to each other, there are three possible isomers of CBs: ortho, meta, and para (Figure 1.3). The weakly acidic $\mathrm{C}-\mathrm{H}$ groups on carboranes can be deprotonated using a strong base such as organolithiates. The $\mathrm{pK}_{\mathrm{a}}$ of the acidic $\mathrm{C}-\mathrm{H}$ are 22.0, 25.6 , and 26.8 respectively for $o-\mathrm{CB}, m-\mathrm{CB}$, and $p-\mathrm{CB} .{ }^{23}$

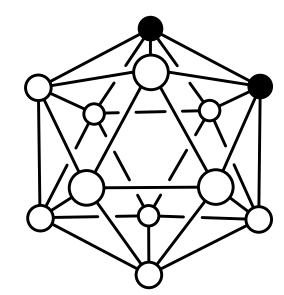

ortho-carborane

$\mathrm{O}=\mathrm{BH}$

$\bullet=\mathrm{CH}$

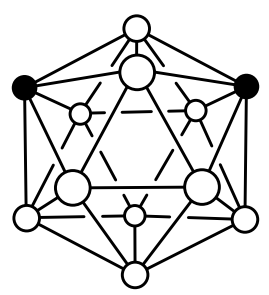

meta-carborane

para-carborane

Figure 1.3 - Carborane isomers.

\subsection{Derivatives of FK866}

Carborane derivatives of FK866 have been developed to enhance selectivity, potency, and solubility and thereby optimize the pharmacokinetics of the drug in biological systems. ${ }^{24}$ These analogues of FK866 have substantial potency, as they have demonstrated enhancement of the drug activity. ${ }^{24}$ After studying the crystal structures of Nampt complexes with NMN and FK866, ${ }^{13}$ the focus was put on the opposite end of the drug. The acrylpyridyl, which resembled NMN, was determined to be the possible active site of FK866. CB derivatives of FK866 were 
obtained by replacing benzoylpiperidyl on FK866 with carborane moiety. Some studies have demonstrated that the hydrophobicity of carboranes assists in the strong interaction between the carborane containing drugs and their receptors. ${ }^{25}$ This interaction is predicted to be the reason for the high potency and the stability of the CB derivatives. The strong interaction between the carborane cage and Nampt (post insertion into the active site), is believed to irreversibly bind the drug inside the active site, hence suppressing the catalytic activity of the enzyme. A crystal structure of bound CB containing drug within the active site of Nampt is still needed to confirm these postulations.

\subsubsection{Previous work}

Several derivatives of FK866 have been synthesized by our group (Figure 1.4). ${ }^{24}$ These derivatives have been used to test cell viability against the A549 human lung cancer cell line. In these studies, the antiproliferative activity of carborane derivatives against cancer cells exhibit a 10-fold increase as well as 100 -fold increase in inhibition of Nampt. ${ }^{24}$ It was predicted that these derivatives behave in a similar fashion as FK866. This prediction was tested by performing a cell rescue assay. This was done by artificial addition of NMN, the product of Nampt catalysis, after treating the cancer cells with FK866 and carborane derivatives of the drug. Cell vitality increased with an increase in the concentration of $\mathrm{NMN}$, and the assay results were nearly identical for all of the drugs tested. ${ }^{24}$ 

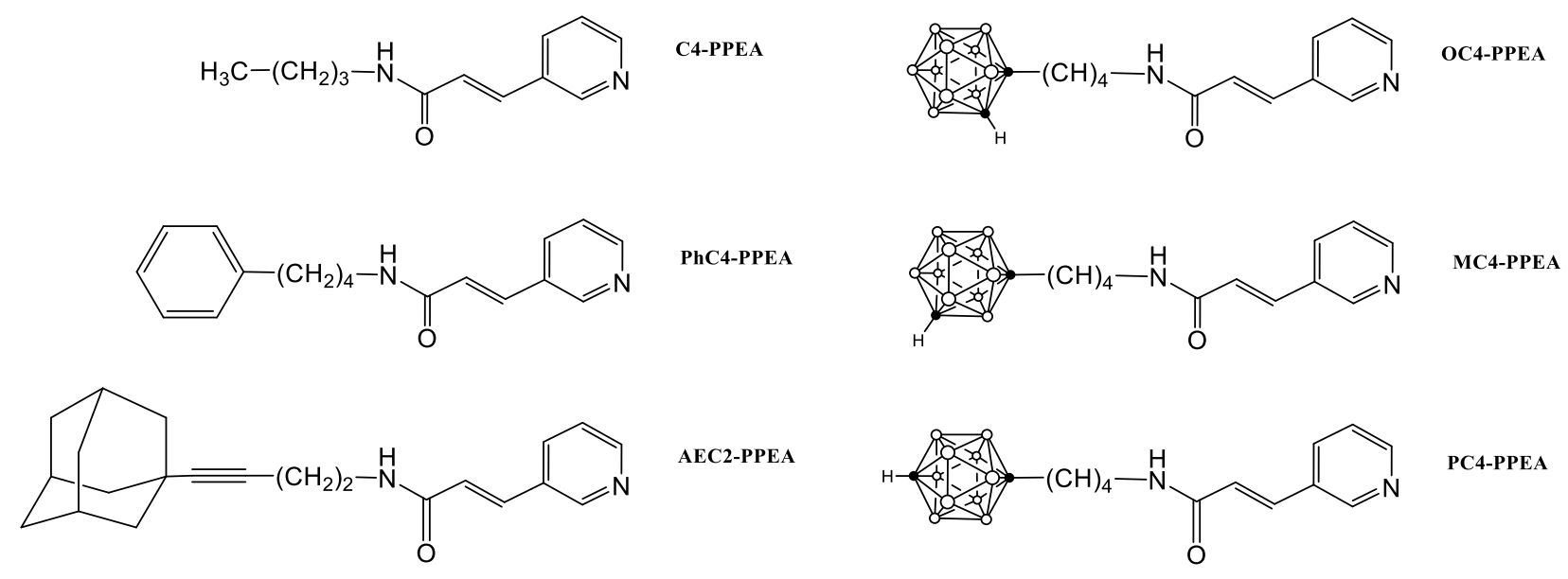

$$
\mathrm{O}=\mathrm{BH}
$$

Figure 1.4 - FK866 derivatives synthesized previously by Lee group. ${ }^{24}$

The most potent carborane derivative of FK866 was found to be the one containing a meta-carborane (MC4-PPEA). ${ }^{24}$ This derivative was selected as the target for further studies. To reproduce the previous results and to further study this molecule, it was essential to optimize the synthetic pathway for a larger scale production. As a cost effective measure, a phenyl derivative of FK866 (PhC4-PPEA) was utilized to design and optimize the new synthetic parameters due to high cost of meta-carborane. Once the ideal yield was achieved, meta-carborane was used. The starting materials for the synthesis of the phenyl derivative of the drug were commercially available and it was possible to achieve high yield using a one-pot two-step synthesis. Phenyl analogue of FK866 served as an inexpensive template for further experimentations.

\subsection{Delivery and targeting}

To avoid cell death in other hyperactive cells in the human body that have high turnover of $\mathrm{NAD}^{+}$, it is crucial to achieve high selectivity to minimize side effects. One of such cells that 
is effected by Nampt inhibition is neutrophil, an abundant type of white blood cell. Nampt is known to inhibit and delay neutrophil apoptosis. ${ }^{26}$ But recently, it has been reported that although the inhibition lowers the $\mathrm{NAD}^{+}$levels in neutrophils, it does not affect the cell viability or bacteria killing ability of the cell. ${ }^{27}$ Nevertheless, Nampt inhibition is still under investigation and it is important to have a targeted delivery system for a selective and efficient administration of the therapeutic agents to the target site.

\subsubsection{Drug modification to make prodrug}

As previously postulated, the acrylpyridyl, which resembled NMN, was the active site of MC4-PPEA and at the opposite end of the molecule, hydrophobic $m$-carborane assists in the strong interaction between the drug and the available hydrophobic residues inside the receptor of the Nampt enzyme. ${ }^{13,24,25}$ By placing a hydroxymethyl group on the second carbon of the carborane in the meta position, we are able to attach linkers and create a prodrug (Scheme 1.2) while keeping the potency of the free drug molecule very high. The activity of the drug was tested using cell viability assay.

Scheme 1.2 - Prodrug design 


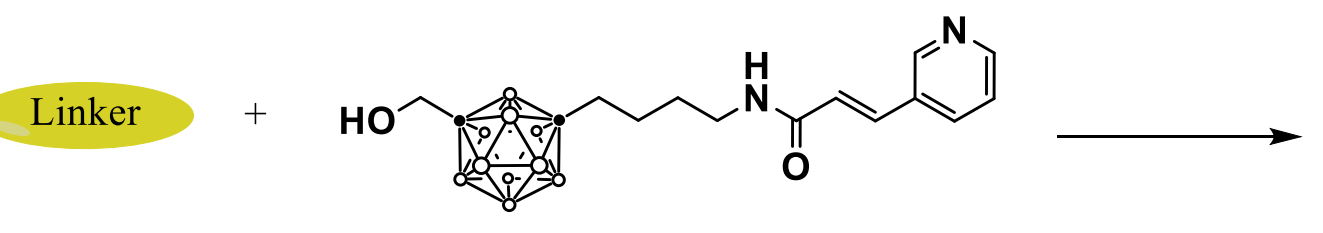

Hydroxymethyl Functionalized Drug

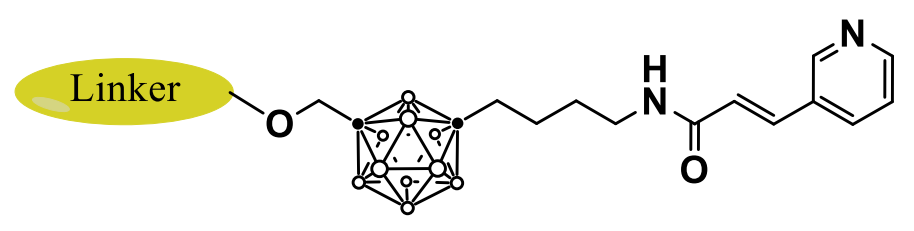

Prodrug

\subsubsection{Hydrolyzable linkers}

For this system to work, it is of great importance to have a linker with different reactive sites. Having an acid chloride, chloroformate, or 4-nitrophenyl carbonate group on one end of the linker helps selectively bond with any drug that contains a primary alcohol or an amine. At the same time, using an azide on the opposite end of the linker allows for click type reactions that are only reactive towards alkynes. This will allow simple attachment of delivery vehicles under very mild conditions, while protecting the integrity of the cleavable linker. Beside tumor targeting peptides, organic fluorescent labels and chelating ligands that host radioactive therapeutic and contrast agents can be utilize for monitoring the movement of the drug in the body and combination of treatments. The linker may also be longer and be made from polyethylene glycols (PEGs) to assist with bioavailability of lipophilic drugs. We have proposed the use of esters, carbamates, and carbonates, which can undergo hydrolysis under various conditions and at various rates. 


\subsubsection{Cyclodextrins (CDs)}

The use of cyclodextrins (CDs) as a possible drug delivery vehicle was also explored. These cyclic oligosaccharides were discovered in 1891 by a French scientist named Villiers. ${ }^{28}$ CDs are made of $\alpha-1,4$-glucosidic linked D-glucose units. There are several derivatives of CDs and they are all products of enzymatic degradation of starch. ${ }^{29}$ Today, CD derivatives are produced almost selectively, efficiently and in high yields, using a class of enzymes called cyclodextrin glucosyltransferases (CGTases). ${ }^{30}$ The most common derivatives of CD include: $\alpha$ cyclodextrin $(\alpha-C D), \beta$-cyclodextrin $(\beta-C D)$, and $\gamma$-cyclodextrin $(\gamma-C D)$, which are made from 6 , 7, and 8 D-glucose units respectively. These molecules have a truncated cone shape with high degree of freedom in aqueous solutions. The interior cavity is hydrophobic but the rims consist of primary hydroxyl groups on one side, and secondary hydroxyl groups on the other. Several representations of $\beta-\mathrm{CD}$ is represented in Figure 1.5.
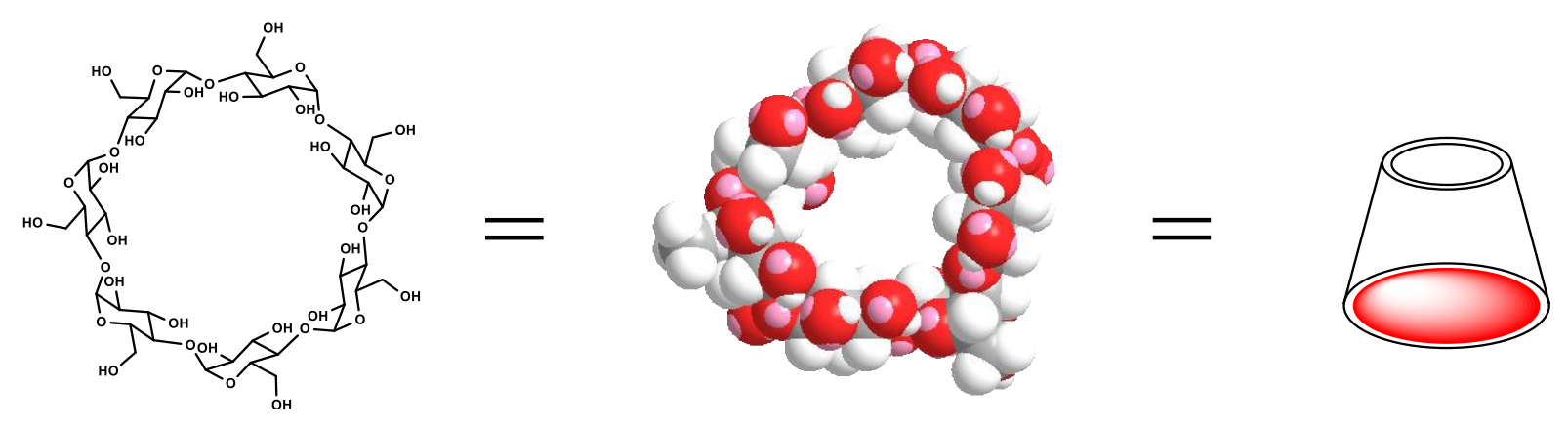

Figure 1.5 - Various representations of $\beta$-cyclodextrin. 
CDs have been extensively research as host-guest complex agent. They have the ability to solubilize lipophilic molecules, such as therapeutic agents, by forming a complex and enhance the bioavailability of the drug molecules. ${ }^{31-34}$ They can also be tailored to behave as drug delivery vehicles. When the CD-drug complex arrives at the target site, the drug can be released due to dilution, change in $\mathrm{pH}$, or interaction of the drug active site with the target receptors in cells. ${ }^{35}$ The inner dimensions of $\beta$-CD are the perfect fit for a $\mathrm{CB}$ and the complexation of these molecules have been a target of extensive research. ${ }^{36-40}$ Although $\beta$-CD has shown the highest affinity toward CB-containing molecules, it has relatively lower solubility in aqueous solutions in comparison to $\alpha$-CD and $\gamma$-CD. ${ }^{32}$ Today, $\beta$-CD s are mostly modified to increase their solubility in aqueous media ${ }^{31-33,41}$ and are also attached to polymers, nanoparticles, and other scaffolds to achieve a multifaceted delivery system. 


\section{Chapter 2 : Improved Synthesis of MC4-PPEA and the Biological Evaluation of its Hydroxymethyl Derivative}

\subsection{Introduction}

There is a need for new antitumoral drugs which are more efficacious against a wide range of cancers. This need is even greater for advanced or recurrent cancers which too often respond poorly to treatments. A promising new target for the treatment of cancer is nicotinamide phosphoribosyltransferase (Nampt), the first and rate limiting enzyme in the mammalian $\mathrm{NAD}^{+}$ recycling pathway, which catalyzes the conversion of nicotinamide to nicotinamide mononucleotide. $\mathrm{NAD}^{+}$is a vital cofactor used throughout cellular respiration, glycolysis, the citric acid cycle, cell signaling, transcription regulation, post-translation protein modification, and the reaction linking cellular respiration with oxidative phosphorylation. Furthermore, SIRTs and PARPs, two classes of $\mathrm{NAD}^{+}$dependent enzymes which are highly implicated in cancer, obtain $\mathrm{NAD}^{+}$primarily from the Nampt mediated recycling pathway. ${ }^{9}$ Nampt has been shown to be upregulated in many/most cancers ${ }^{42-49}$ and this overexpression is highest in aggressive and refractory cancers. ${ }^{16,50}$ Nampt overexpression is predictive of poor response to the treatment of

various cancers. ${ }^{16,50}$ Most healthy cells do not depend on the Nampt mediated pathway. ${ }^{15,51}$

The first known small molecular inhibitor of Nampt, designated FK866/APO866, was previously investigated in a number of Phase I/II clinical trials against several cancers. ${ }^{14}$ While treatment of patients with the drug was determined to be well tolerated and safe, the dose limiting toxicity (thrombocytopenia) prevented the delivery of an efficacious dose. ${ }^{52}$ Our 
research group recently reported a new family of carborane-containing Nampt inhibitors which exhibit low-nanomolar potencies against several human cancer cell lines in vitro. ${ }^{24}$ Our most potent derivative, MC4-PPEA (4), exhibited a 10-fold higher activity and an approximately 100fold greater inhibition of Nampt in vitro when compared with FK866. Recently, the subnanomolar potency of our agent 4 was reported by an independent research group. ${ }^{53}$ When these inhibitors are bound in Nampt, the acrylpyridyl moiety of the molecule binds to residues near the catalytic site of the enzyme which is accessed through a narrow tunnel. The distal bulky, hydrophobic group of the inhibitor blocks the entrance to this tunnel; a benzoylpiperidine in FK866, a carborane moiety in our molecules (Figure 2.1).

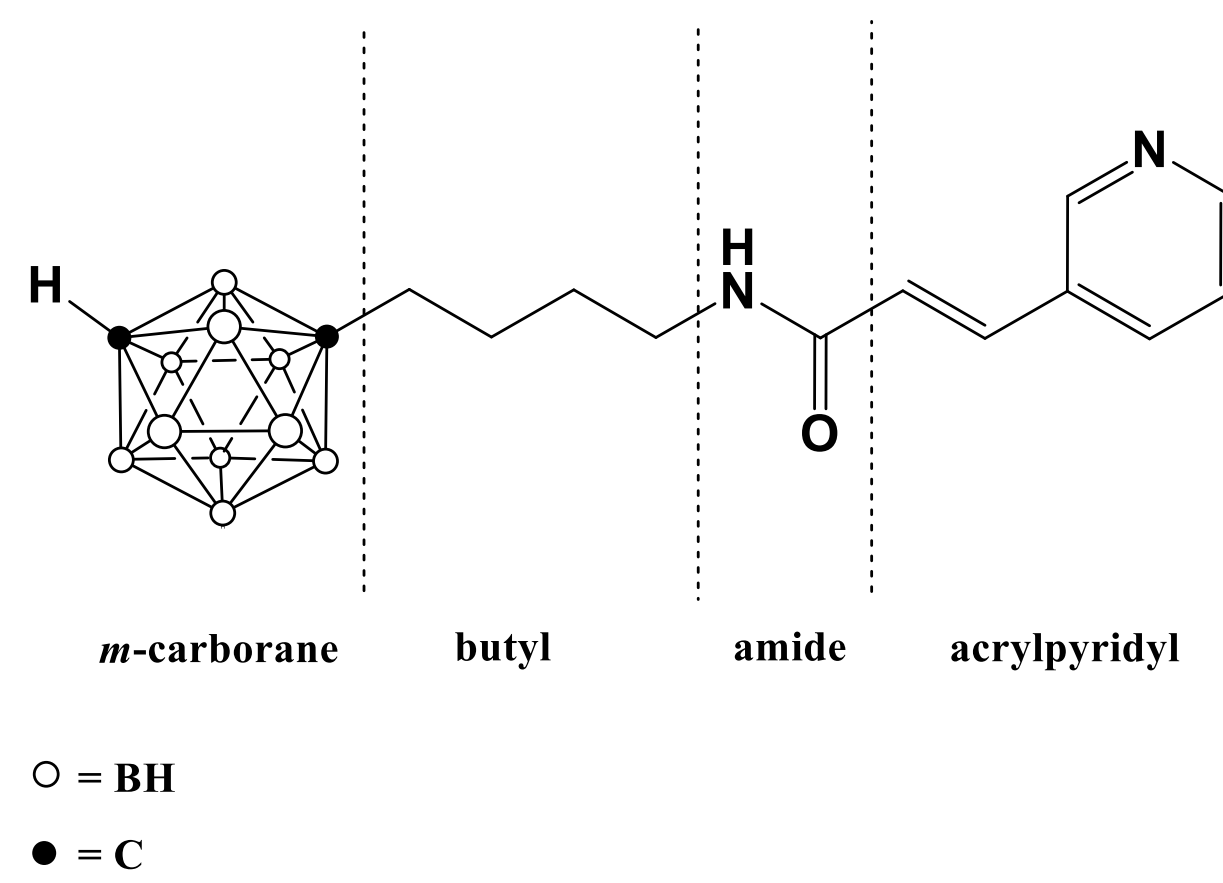

Figure 2.1 - Components that make up the structure of MC4-PPEA (4).

Our most potent Nampt inhibitor was found to be one containing a meta-carborane isomer. ${ }^{24}$ In the present study, we have optimized the synthesis of $\mathbf{4}$ using a new route towards 
the intermediate amine, significantly improving both the scalability and yield of the product. We have also synthesized a new derivative of $\mathbf{4}$ bearing a hydroxymethyl group appended to the meta-carborane moiety (11). This group will serve as a site for covalent attachment of the molecule through various hydrolysable linkers for the purposes of synthesizing targeted prodrugs of our Nampt inhibitors in future work. The potency of this new derivative was tested using cell viability assays in human breast cancerous and noncancerous cell lines.

Furthermore, as a cost effective measure, phenyl (12), morpholine (16), and piperidine (19) derivatives were synthesized due to high cost of meta-carborane. 12 was synthesized to serve as an inexpensive template for further experimentations. The starting materials for the synthesis of the phenyl derivative of the drug were commercially available and using a one-pot two-step synthesis it was possible to achieve high yields.

\subsection{Results and Discussions}

\subsubsection{Synthesis of MC4-PPEA (4)}

In our initial report, we prepared $40 \mathrm{mg}$ of $\mathbf{4}$ using a total of four steps in seven percent yield overall. Here, we have improved the overall synthetic yield to twenty one percent, while increasing the scale of the reactions by a factor of 20 . The synthesis of $\mathbf{4}$, as previously described, ${ }^{24}$ and the sequence of reactions leading to optimized and improved synthesis of $\mathbf{4}$ are demonstrated in Scheme 2.1. 
Scheme 2.1 - Previously reported synthetic pathway (a) and improved procedure (b) to synthesize 4

(a)

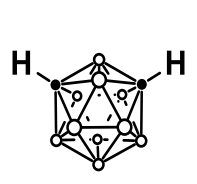

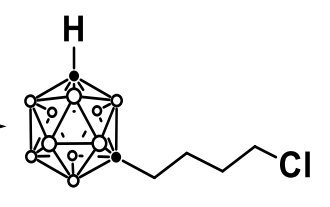
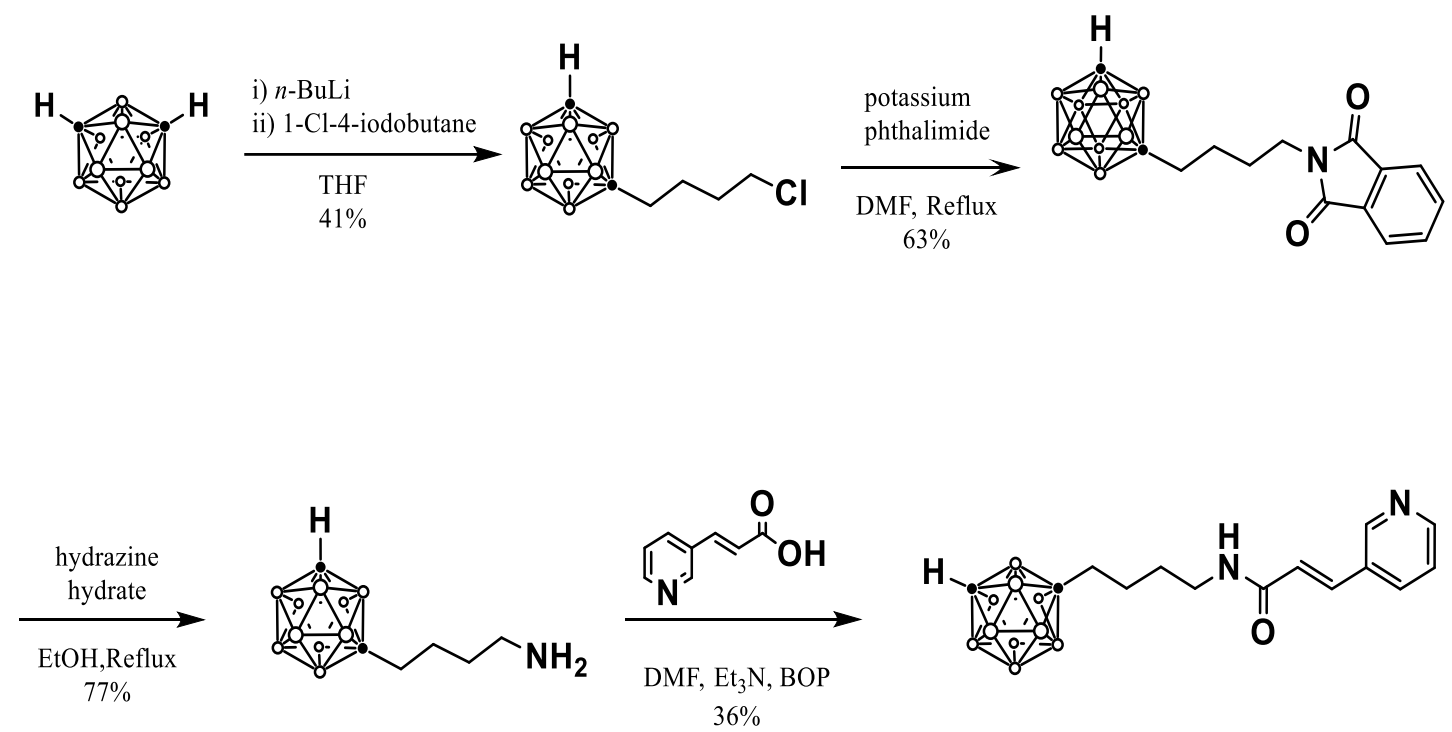

(b)
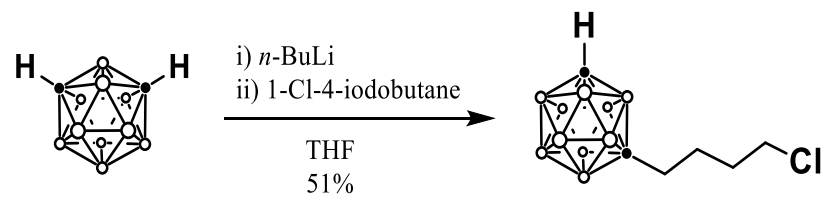

$1 a$
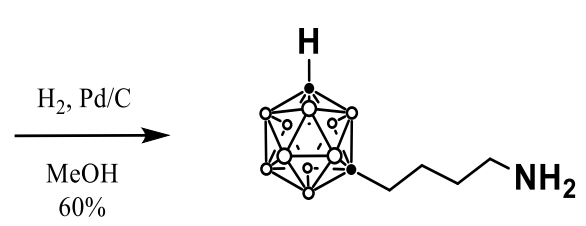

3

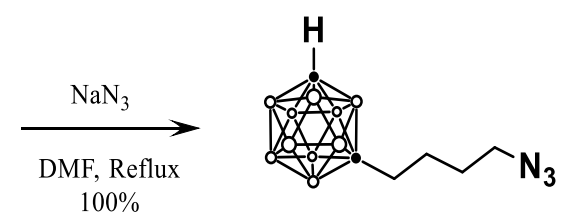

2

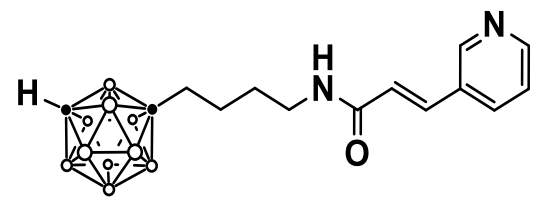

$\mathrm{O}=\mathrm{BH}$

$0=\mathrm{C}$ 
To synthesize 4, $m$-CB was first activated using $n$-butyllithium, allowing for a metalation type reaction on the weakly acidic C-H proton to create nucleophilic sites. ${ }^{25}$ These nucleophiles can be used to prepare a wide range of carborane based complexes (Scheme 2.2). ${ }^{25}$

Scheme 2.2 - Metalation of $m$-carborane using $n$-butyllithium

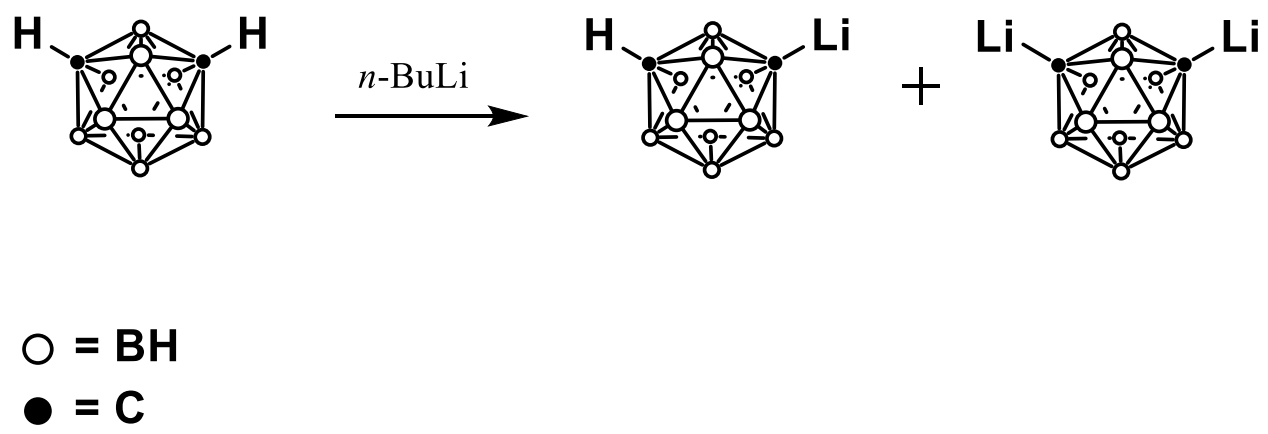

The lithiated $m$-CB was then reacted with 1-chloro-4-iodobutane, producing 1-(4chlorobutyl)- $m$-carborane (1a) as a colorless oil with a yield of $51 \%$. The di-substituted product (1b) (yield of 32\%) and some starting material were also recovered. Both mono- and disubstituted products were isolated using column chromatography on silica gel. The reactions following this step involved manipulation of the terminal end of the substituted alkyl group placed on the carborane cage and did not involve the cage itself.

The chloride on compound 1a was exchanged with an azide using sodium azide in and $\mathrm{S}_{\mathrm{N}} 2$ type reaction to afford, 1-(4-azidobutyl)- $m$-carborane (2) as a colorless oil with a yield of 100\%. Compound 2 was reduced using palladium on activated carbon under a hydrogen atmosphere to afford 1-(4-aminobutyl)- $m$-carborane (3) as a yellow oil with $60 \%$ yield. MC4PPEA (4) was synthesized by converting trans-3-(3'-pyridyl)acrylic acid to the acid chloride, making it more susceptible to react with the amine without the need for a coupling agent, such as 
the benzotriazole-1-yl-oxy-tris-(dimethylamino)-phosphonium hexafluorophosphate (BOP) used previously. In a one-pot, two-step reaction, trans-3-(3'-pyridyl)acrylic acid was treated with thionyl chloride; DMF was used as a catalyst to achieve trans-3-(3'-pyridyl)acryloyl chloride. Sulfur dioxide and hydrochloric acid gas were produced as byproducts and removed by evacuating the reaction vessel under vacuum. The product was redissolved in THF and the remaining acid was captured using Hünig's base. A THF solution of $\mathbf{3}$ was then added drop-wise and the reaction mixture was allowed to stir overnight. This reaction afforded 1-(4'-(trans-3"(3"'-pyridyl)acrylamido)butyl)-1,7-dicarbadodecaborane (4) as an orange foam with 69\% yield, significantly improved over the $36 \%$ observed during the previous report.

One reason that the use of BOP as a coupling reagent was avoided was owing to the challenge of isolating the product from the many byproducts that result from that reaction. One such byproduct was hexamethylphosphoramide (HMPA) which is a polar aprotic solvent with a high boiling point $\left(232.5^{\circ} \mathrm{C}\right)$. HMPA is known to be carcinogenic and its complete removal was not possible using flash chromatography. Due to the presence of HMPA, the product stayed in solution as a thick yellow oil. Previously, it was necessary to utilize high performance liquid chromatography (HPLC) to recover $\mathbf{4}$ as a pure solid product. The purification of product using HPLC was time consuming and was not practical at the gram scale.

\subsubsection{Synthesis of hydroxymethyl functionalized MC4-PPEA (11)}

The synthetic route for hydroxymethyl functionalized MC4-PPEA (11) is depicted in Scheme 2.3. An acidic proton on one of the carbon atoms of $m$-carborane was removed using $n$ butyllithium and the lithiated $m$-carborane was then reacted with paraformaldehyde. ${ }^{37}$ After quenching the reaction with $2 \mathrm{~N} \mathrm{HCl}_{(\mathrm{aq})}, 1$-(hydroxymethyl)-m-carborane (5a) was afforded as a 
white solid with a yield of 59.3\%. The di-substituted product (5b) (yield of $31.1 \%$ ) and some starting material were also recovered and isolated using column chromatography on silica gel. The hydroxyl group was then protected using a trityl group so that the second carbon on the $m$ carborane cage could be manipulated. This was achieved using trityl chloride and Hünig's base to afford 1-(methyl triphenylmethyl ether)-1,7-dicarbadodecaborane (6) as a white solid with a yield of $92.3 \%$.

Scheme 2.3 - Synthesis of hydroxymethyl functionalized MC4-PPEA (11) drug
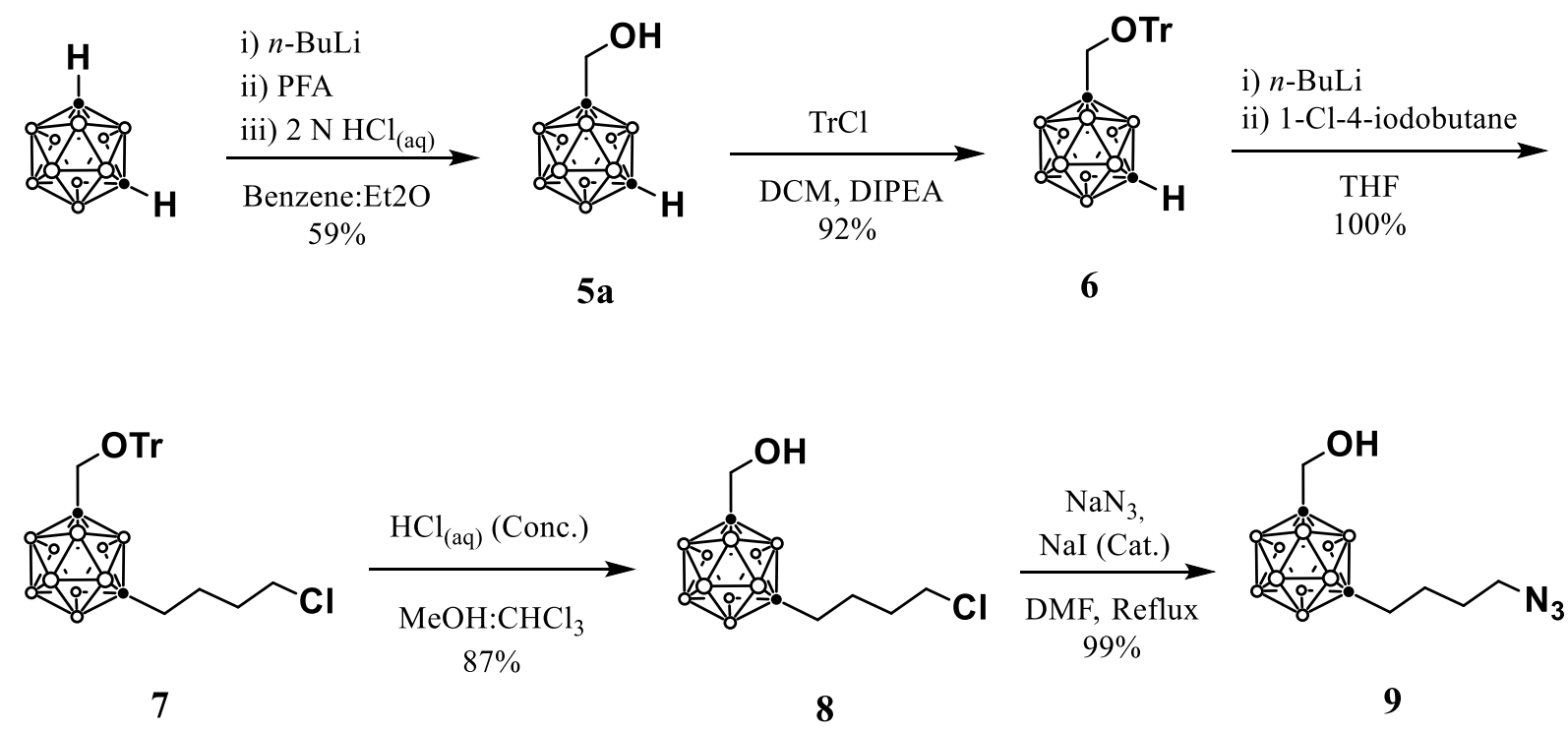

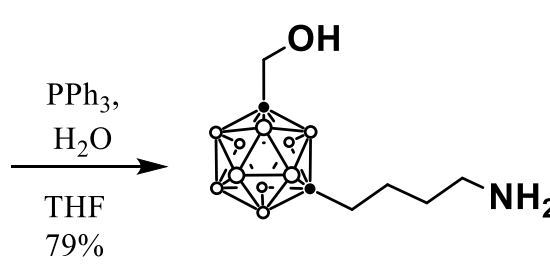

10

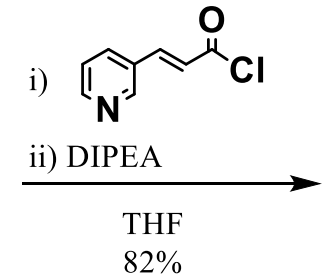

$82 \%$<smiles>O=C(/C=C/c1cccnc1)NCCCCC12C=CC(O1)C1(CO)CCC2C1</smiles>

11

$\mathrm{O}=\mathrm{BH}$

$\bullet=\mathrm{C}$ 
Compound $\mathbf{6}$ was further modified by activating the unsubstituted carbon on the $m$ carborane moiety using $n$-butyllithium and then reacted with 1-chloro-4-iodobutane, producing 1-(methyl triphenylmethyl ether)-7-(4-Chlorobutyl)-m-carborane (7) as a yellow oil with a yield of $100 \%$. Following this, the trityl protecting group on compound 7 was removed using concentrated $\mathrm{HCl}$ to afford 1-(hydroxymethyl)-7-(4-Chlorobutyl)-m-carborane (8) as a yellow oil with a yield of $87.2 \%$. In a manner similar to that employed on $\mathbf{2}$, the chloride on compound $\mathbf{8}$ was exchanged with an azide using sodium azide to afford, 1-(hydroxymethyl)-7-(4-Azidobutyl)1,7-dicarbadodecaborane (9) as a yellow oil with a yield of 98.6\%. Compound 9 was reduced using triphenylphosphine $\left(\mathrm{PPh}_{3}\right)$ instead of palladium on activated carbon. We observed the presence of secondary and tertiary amines in small quantities when reduction was done using palladium. Post reduction, 1-(hydroxymethyl)-7-(4-Aminobutyl)-m-carborane (10) was afforded as an orange oil with $87.5 \%$ yield.

The hydroxymethyl derivative hm-MC4-PPEA was synthesized in a similar method as that employed for 4 by converting trans-3-(3'-pyridyl)acrylic acid to trans-3-(3'-pyridyl)acryloyl chloride (PAC) in a one-pot, two-step reaction. To minimize a reaction between the hydroxyl group and PAC, both solutions of $\mathbf{1 0}$ and PAC were prepared separately and chilled to $-78^{\circ} \mathrm{C}$ using an acetone/dry-ice bath and the PAC solution was added drop-wise to the solution containing $\mathbf{1 0}$ and the reaction mixture was allowed to stir overnight while gradually reaching ambient temperature. This reaction afforded 1-(hydroxymethyl)-7-(4'-(trans-3"-(3"'pyridyl)acrylamido)butyl)- $m$-carborane (11) as an orange foam with $75.9 \%$ yield.

The activity of $\mathbf{1 1}$ was evaluated using MTT assay, ${ }^{54}$ against three human breast cell lines: MCF7, T47D, (both cancerous) and 184A1 (noncancerous breast epithelium). Figure 2.2 
depicts the concentration dependent cell viability exhibited by $\mathbf{1 1}$ against these cell lines in vitro. The compound exhibited $\mathrm{IC}_{50}$ of $58.0 \pm 5.2 \mathrm{nM}, 12.0 \pm 2.1 \mathrm{nM}$, and $3.9 \pm 1.3 \mathrm{nM}$ for MCF7, T47D, and 184A1 cancer cell lines, respectively. These assays suggest that the addition of a hydroxymethyl moiety to 4 , producing compound $\mathbf{1 1}$, results in an approximate 10 -fold decrease in potency for the new molecule. However, 11 still exhibits low nanomolar potencies in vitro and the presence of the hydroxymethyl group should allow for its covalent attachment to hydrolyzable linkers for the purpose of targeted drug delivery using cancer associated vectors. Such efforts are underway now in our laboratory and will be reported shortly.

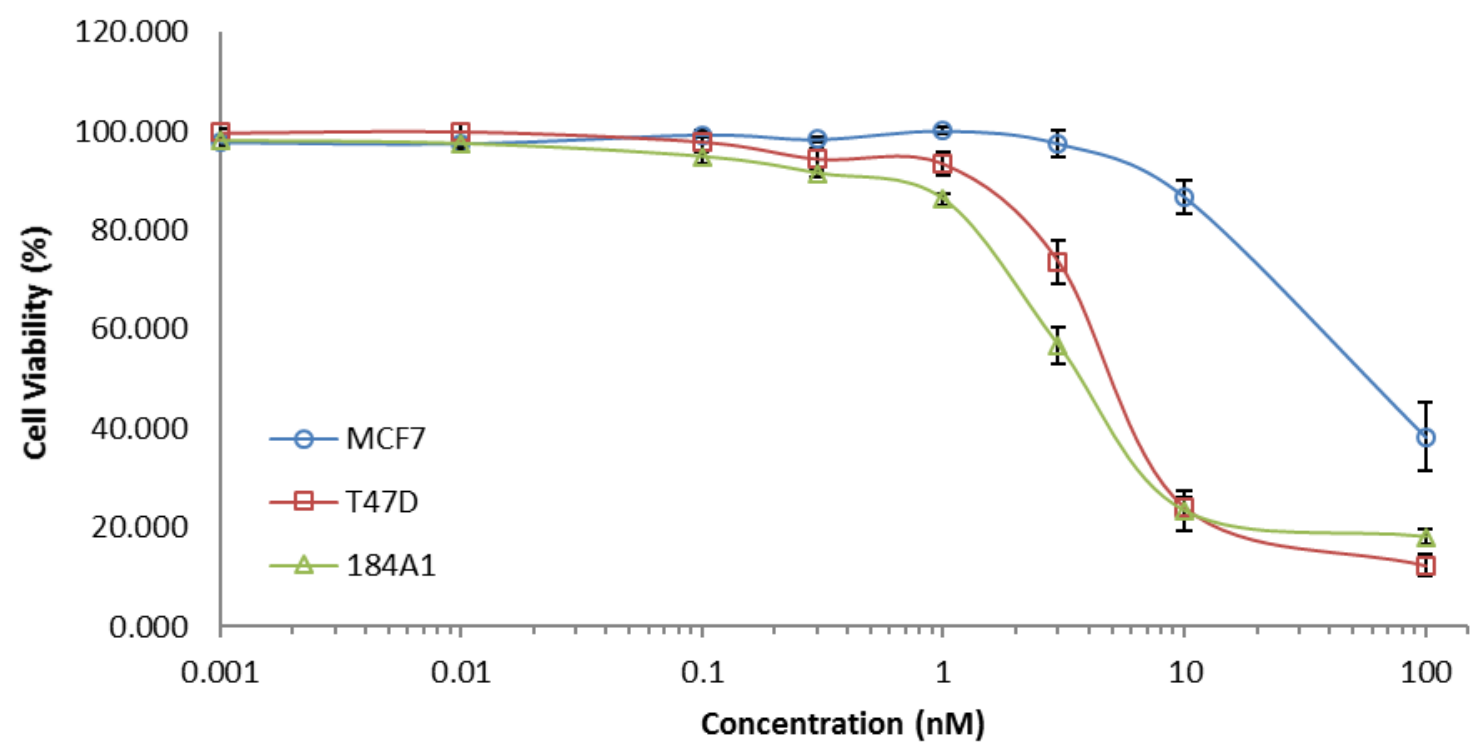

Figure 2.2 - Percent cell viability of human breast cancer cell lines: MCF7, T47D, and noncancerous breast epithelium 184A1 at various concentrations of $\mathbf{1 1 .}$

\subsubsection{Synthesis of other derivatives of MC4-PPEA}


The phenyl derivative of our drug (12) had been previously synthesized using BOP as the coupling agent. ${ }^{24}$ Herein 12 was synthesized in a similar method as that employed previously, utilizing PAC in a one-pot, two-step reaction. Using this method a yellow foam was afforded with a high yield of $76 \%$ (Scheme 2.4).

Scheme 2.4 - Improved synthesis of (12)

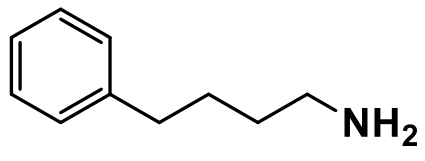

4-phenylbutylamine i)<smiles>O=C(Cl)/C=C/c1cccnc1</smiles>

ii) DIPEA

THF

$76 \%$<smiles>O=C(/C=C/c1cccnc1)NCCCCc1ccccc1</smiles>

12

Other derivatives were also synthesized in a similar fashion. First 4-chlorobutyronitrile was converted to 4-iodobutyronitrile (13) using sodium iodide in anhydrous acetone as described in the literature (Scheme 2.5) ${ }^{55}$ Iodine is a good leaving group, making this linker susceptible to nucleophilic attack. Post workup, a light yellow color oil was recovered with a yield of $96 \%$.

Scheme 2.5 - Synthesis of 4-iodobutyronitrile (13)<smiles>N#CCCCCl</smiles>

4-chlorobutyronitrile

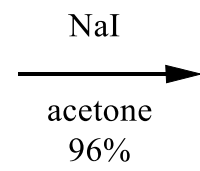


Morpholine was used as the nucleophile and it was reacted with $\mathbf{1 3}$ to afford compound 14 as a clear oil with a yield of $83.2 \% .14$ was reduced using lithium aluminum hydride in anhydrous DMF to afford a primary amine (15) as a yellow oil with a yield of $69.5 \%$. The synthetic procedures to produce 14, and $\mathbf{1 5}$ were adapted from the literature. ${ }^{56}$ The primary amine was reacted with PAC using the same method described previously to afford morpholine derivative of our Nampt inhibitor (16) as an orange solid with a yield of $12 \%$. The sequence of reactions leading to synthesis of $\mathbf{1 6}$ is demonstrated in Scheme 2.6.

Scheme 2.6 - Synthesis of morpholine derivate (16) of the Nampt inhibitor

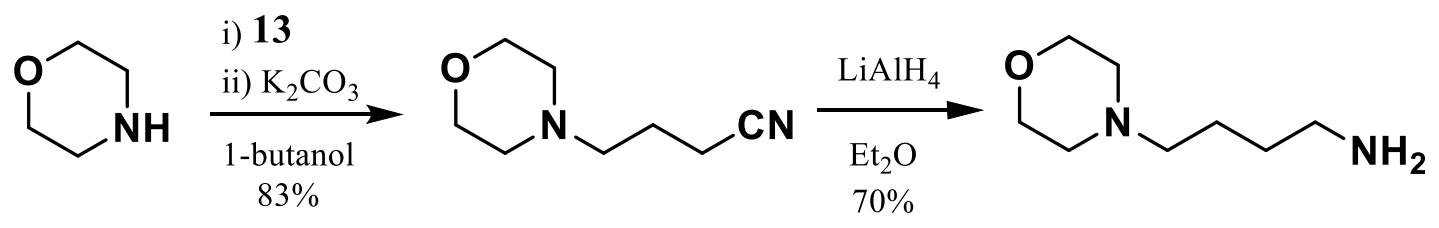

14

15
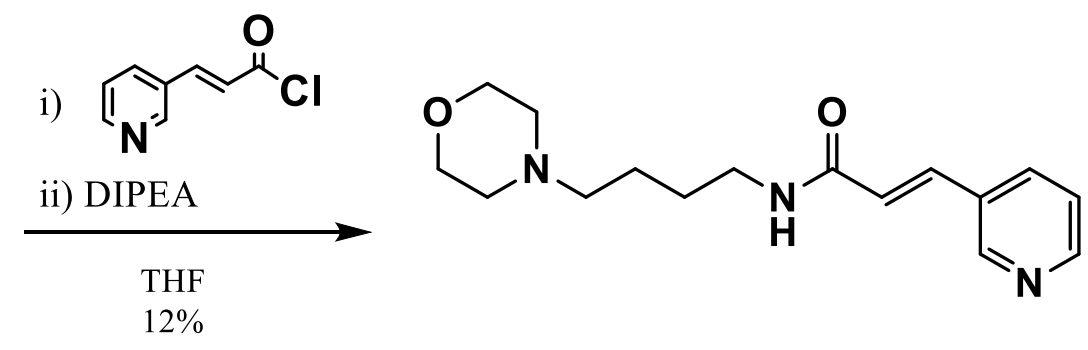

16

Piperidine derivative of our Nampt inhibitor was made following the same procedure described previously for $\mathbf{1 6}$. Piperidine was reacted with $\mathbf{1 3}$ to afford compound $\mathbf{1 7}$ as a clear oil with a yield of $83 \% .17$ was reduced using lithium aluminum hydride in anhydrous DMF to 
afford a primary amine (18) as a yellow oil with a yield of 83.6\%. 18 was reacted with PAC using the same method described previously to afford piperidine derivative of our Nampt inhibitor (19) as an orange solid with a yield of 38.4\%. No tests were performed on 16, and 19 so there were no further attempts made to improve the yields. The sequence of reactions leading to synthesis of $\mathbf{1 9}$ is demonstrated in Scheme 2.7.

Scheme 2.7 - Synthesis of piperidine derivate (19) of the Nampt inhibitor<smiles>CCOC(=O)C=NCCCN1CCCCC1CC(=O)OCC</smiles>

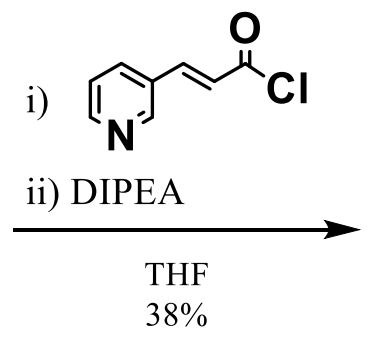<smiles>O=C(/C=C/c1cccnc1)NCCCCN1CCCCC1</smiles>

19

\subsection{Conclusion}


A significantly improved synthesis of MC4-PPEA has been described. A new hydroxymethyl functionalized derivative of $\mathbf{4}$ was also synthesized in high yield. High potencies of the new derivative were observed in three human breast cell lines in vitro. The hydroxymethyl moiety of $\mathbf{1 1}$ should allow for the bonding of short hydrolyzable covalent linkages as a means for attaching this molecule to drug delivery vehicles, such as nanoparticles, proteins, or antibodies. The selective delivery of highly potent Nampt inhibitors to tumor tissue might overcome some of the limitations observed from early clinical trials of APO866. Other derivatives of MC4-PPEA were synthesized as cost effective alternative to serve as a template for further experimentations.

\subsection{Experimental}

\subsubsection{Material}

All manipulations were performed under an argon atmosphere unless stated otherwise. All anhydrous solvents; $n$-butyllithium (2.5 M solution in hexane), $n$-BuLi; paraformaldehyde, PFA; trityl chloride, $\mathrm{TrCl}$; 1-chloro-4-iodobutane, $\mathrm{Cl}\left(\mathrm{CH}_{2}\right)_{4} \mathrm{I} ; \mathrm{HCl}(37 \%)$; sodium azide, $\mathrm{NaN}_{3}$; sodium iodide, $\mathrm{NaI}$; potassium iodide, $\mathrm{KI}$; $10 \%$ palladium on activated carbon, $\mathrm{Pd} / \mathrm{C}$; triphenylphosphine, $\mathrm{PPh}_{3}$; magnesium sulfate, $\mathrm{MgSO}_{4}$; sodium sulfate, $\mathrm{Na}_{2} \mathrm{SO}_{4}$; trans-3-(3'pyridyl)acrylic acid, $\mathrm{C}_{5} \mathrm{NH}_{4}(\mathrm{CH})_{2} \mathrm{COOH}$; thionyl chloride, $\mathrm{SOCl}_{2}$; Hünig's Base, DIPEA; pyridine, $\mathrm{C}_{5} \mathrm{H}_{5} \mathrm{~N}$; piperidine; morpholine; potassium carbonate, $\mathrm{K} 2 \mathrm{CO} 3$; lithium aluminum hydride, LiAlH4; sodium potassium tartrate; 4-phenylbutylamine; 4-chlorobutyronitrile were purchased from Aldrich and used as received. High purity grade $\mathrm{H}_{2}$ gas was purchased from Airgas. All solvents were dried using $3 \AA$ molecular sieves $(20 \% \mathrm{~m} / \mathrm{v}) .{ }^{57}$ Silica gel was

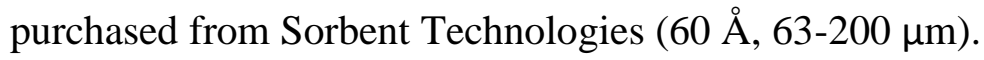




\subsubsection{Instrumentation}

NMR spectra were recorded on Bruker DRX300, DRX500, AVANCE III 400 and AVANCEE II 500 Nuclear Magnetic Spectrometers. Spectrometers and analyzed using TopSpin. Chemical shifts $(\delta, \mathrm{ppm})$ for ${ }^{1} \mathrm{H}$ and ${ }^{13} \mathrm{C}$ were referenced to residual solvent peaks. Mass spectra were measured using a Mariner Biospectrometry time of flight spectrometer by PerSeptive Biosystems, equipped with electrospray ionization operating under both positive and negative modes and reported in $\mathrm{m} / \mathrm{z}$.

\subsubsection{Cell cultures and treatment}

All cell lines were obtained from ATCC (Manassas, VA). MCF-7 and T47D cells were maintained in DMEM media containing $350 \mu \mathrm{l} \cdot \mathrm{L}^{-1}$ gentamicin and $25 \mathrm{ml} \cdot \mathrm{L}^{-1}$ fetal bovine serum. 184A1 cells were maintained in HuMEC media containing $175 \mu \mathrm{l} \cdot \mathrm{L}^{-1}$ gentamicin, HuMEC supplement, and bovine pituitary extract. The cells were grown to confluency in either T-12.5 $\mathrm{cm}^{2}$ or $\mathrm{T}-25 \mathrm{~cm}^{2}$ tissue culture flasks using an incubator maintained at $5 \% \mathrm{CO}_{2}$ humid atmosphere at $37^{\circ} \mathrm{C}$. The MTT assay ${ }^{54}$ was carried out as follows: MCF-7, T47D, and 184A1 cells were plated in 96 well plates at a density of 10,000 cells per well for overnight at $37{ }^{\circ} \mathrm{C}$. The cells were then treated with different doses of the test agent for $72 \mathrm{~h}$. MTT reagent was added to the cells for $4 \mathrm{~h}$ for developing formazan crystals. Solubilization buffer was added to the wells and the absorbance was measured at $570 \mathrm{~nm}$. The experiments were repeated four times and the standard deviations are reported.

\subsubsection{The procedure for the synthesis of $1 \mathrm{a}-4$}


1-(4-chlorobutyl)-1,7-dicarbadodecaborane (1a). In a $50 \mathrm{~mL}$ round bottom flask, $m$ carborane $(2.16 \mathrm{~g}, 15.0 \mathrm{mmol})$ was dissolved in anhydrous THF $(20 \mathrm{~mL})$. The solution was cooled to $-20{ }^{\circ} \mathrm{C}$, while stirring, and $2.5 \mathrm{M}$-butyllithium in hexane $(6.00 \mathrm{~mL}, 15.0 \mathrm{mmol})$ was added drop wise. The reaction mixture was allowed to reach ambient temperature before it was cooled to $-20{ }^{\circ} \mathrm{C}$ again and 1-chloro-4-iodobutane $(1.84 \mathrm{~mL}, 15.0 \mathrm{mmol})$ was added. The resulting solution was allowed to stir overnight while slowly reaching ambient temperature. To quench the reaction, $10 \mathrm{~mL}$ of de-ionized water was used and the mixture was extracted with dichloromethane $(3 \times 20 \mathrm{~mL})$. The organic phase was washed with brine and dried over anhydrous sodium sulfate. Solvent was removed under reduced pressure and crude product was purified by silica gel column chromatography using hexane, to afford $1.78 \mathrm{~g}$ of $\mathbf{1 a}$ as a colorless oil. (Yield: $51 \%$ ). $0.78 \mathrm{mg}$ of the di-substituted product $\mathbf{1 b}$ was also isolated. (Yield: $16 \%$ ). 1a: ${ }^{1} \mathrm{H}$ NMR $\left(500 \mathrm{MHz}_{\mathrm{CDCl}}\right): \delta=3.50(\mathrm{t}, 2 \mathrm{H}, J 10), 2.91(\mathrm{~s}, 1 \mathrm{H}), 1.95(\mathrm{~m}, 3 \mathrm{H}), 1.69(\mathrm{p}, 2 \mathrm{H}, J 5.0), 1.52(\mathrm{p}$ $2 \mathrm{H}, J$ 5.0), 3.31-1.55 (10H, BH). $\left.{ }^{13} \mathrm{C} \mathrm{NMR} \mathrm{(125} \mathrm{MHz,} \mathrm{CDCl}_{3}\right): \delta=76.23,55.21,44.58,36.49$, 32.23, 27.56. 1a: HRMS (APCI, neg.): calcd. for $\mathrm{C}_{6} \mathrm{H}_{19} \mathrm{~B}_{10} \mathrm{Cl}[\mathrm{M}] 234.2149$, found: 234.2237. 1b: HRMS (APCI, neg.): calcd. for $\mathrm{C}_{10} \mathrm{H}_{26} \mathrm{~B}_{10} \mathrm{Cl}_{3}$ [M+Cl] $]^{-}$360.2091, found: 360.2152.

1-(4-azidobutyl)-1,7-dicarbadodecaborane (2). In a $100 \mathrm{~mL}$ round bottom flask, $1 \mathrm{a}$ (1.50 g, $6.39 \mathrm{mmol})$ was dissolved in DMF (30 mL). Sodium azide (1.25 g, $19.2 \mathrm{mmol})$ and catalytic amount of $\mathrm{NaI}(0.10 \mathrm{~g}, 0.64 \mathrm{mmol})$ was added to the reaction mixture. The reaction mixture was covered with foil and refluxed overnight at $64^{\circ} \mathrm{C}$. The solvent was evaporated and the crude product was redissolved in DCM $(10 \mathrm{~mL})$ and washed with deionized water $(3 \times 5 \mathrm{~mL})$. The organic phase was dried over anhydrous sodium sulfate and solvent was removed under reduced pressure to afford $1.07 \mathrm{~g}$ of 2 as a colorless oil. (Yield: $67 \%) .{ }^{1} \mathrm{H}$ NMR (400 MHz, $\left.\mathrm{CDCl}_{3}\right): \delta=3.26(\mathrm{t}, 2 \mathrm{H}, J$ 6.3), $2.91(\mathrm{~s}, 1 \mathrm{H}), 1.95(\mathrm{t}, 2 \mathrm{H}, J 8.8), 1.48(\mathrm{~m}, 4 \mathrm{H}), 3.33-1.41(10 \mathrm{H}$, 
BH). ${ }^{13} \mathrm{C}$ NMR $\left(100 \mathrm{MHz}, \mathrm{CDCl}_{3}\right): \delta=76.25,55.24,51.30,36.78,28.79,27.47$. HRMS

(GC/APCI, neg.): calcd. for $\mathrm{C}_{6} \mathrm{H}_{19} \mathrm{~B}_{10} \mathrm{~N}_{3}\left[\mathrm{M}-\mathrm{N}_{2}\right]^{-}$213.35, found: 212.23 .

1-(4-aminobutyl)-1,7-dicarbadodecaborane (3). In a $100 \mathrm{~mL}$ round bottom flask, 2 $(1.50 \mathrm{~g}, 6.22 \mathrm{mmol})$ was dissolved in anhydrous methanol (20 mL). Catalytic amount of $10 \%$ $\mathrm{Pd} / \mathrm{C}(0.66 \mathrm{~g}, 0.62 \mathrm{mmol})$ was added to the reaction mixture and a balloon was used to pump hydrogen into the reaction vessel. The reaction vessel was purged every 2 hours for 8 hours, to expel any $\mathrm{N}_{2}$ gas that was produced as the byproduct and the reaction was allowed to stir overnight at room temperature. The solvent was evaporated and the crude product was redissolved in DCM $(10 \mathrm{~mL})$ and washed with deionized water $(10 \mathrm{~mL})$. The organic layer was collected and washed using brine $(10 \mathrm{~mL})$ and the crude product was extracted with dichloromethane $(3 \times 10 \mathrm{~mL})$. The organic phase was collected and dried over anhydrous sodium sulfate and solvent was removed under reduced pressure and crude product was purified by silica gel column chromatography using 100\% DCM, 7\% MeOH/DCM, 50\% MeOH/DCM, and 100\% $\mathrm{MeOH}$ respectively as eluents, to afford $810 \mathrm{mg}$ of $\mathbf{3}$ as a colorless oil. (Yield: 60\%). ${ }^{1} \mathrm{H}$ NMR (400 MHz, $\left.\mathrm{CDCl}_{3}\right): \delta=2.89(\mathrm{~s}, 1 \mathrm{H}), 2.64(\mathrm{t}, 2 \mathrm{H}, J 6.45 \mathrm{~Hz}), 1.92(\mathrm{t}, 2 \mathrm{H}, J 7.9), 1.35(\mathrm{~m}, 4 \mathrm{H})$, 2.89-1.35 (10H, BH). ${ }^{13} \mathrm{C}$ NMR (100 MHz, $\left.\mathrm{CDCl}_{3}\right): \delta=76.72,55.16,42.04,37.16,33.51,27.67$. HRMS (APCI, pos.): calcd. for $\mathrm{C}_{6} \mathrm{H}_{21} \mathrm{~B}_{10} \mathrm{~N}[\mathrm{M}+\mathrm{H}]^{+} 216.2753$, found: 217.2574 .

\section{1-(4'-(trans-3"-(3"'-pyridyl)acrylamido)butyl)-1,7-dicarbadodecaborane (4). In a 250}

$\mathrm{mL}$ 2-neck round bottom flask, trans-3-(3'-pyridyl)acrylic acid (0.51 g, $3.4 \mathrm{mmol})$ was suspended in anhydrous THF (20 mL) and DMF (1 mol\%) was added as a catalyst. The solution was cooled to $0{ }^{\circ} \mathrm{C}$, while stirring, and thionyl chloride $(0.81 \mathrm{~g}, 0.50 \mathrm{~mL}, 6.8 \mathrm{mmol})$ was added drop wise and the reaction mixture was allowed to reach ambient temperature while stirring 
overnight. The following day, the vessel was evacuated under reduced pressure to remove solvent and any gaseous byproducts. The crude product was redissolved in anhydrous THF (15 $\mathrm{mL})$ and cooled to $0{ }^{\circ} \mathrm{C.} 3(0.67 \mathrm{~g}, 3.1 \mathrm{mmol})$ was dissolved in anhydrous THF $(5 \mathrm{~mL})$ and Hünig's Base $(1.86 \mathrm{~g}, 2.50 \mathrm{~mL}, 14.4 \mathrm{mmol})$ and added drop wise to the reaction vessel. The resulting solution was allowed to stir overnight while slowly reaching ambient temperature. The crude product was redissolved in DCM $(10 \mathrm{~mL})$ and washed with saturated solution of sodium bicarbonate $(20 \mathrm{~mL})$. The organic layer was collected and in a separating funnel, water $(10 \mathrm{~mL})$ was added and the crude product was extracted with dichloromethane $(3 \times 10 \mathrm{~mL})$. The organic phase was washed using brine $(10 \mathrm{~mL})$ and dried over anhydrous sodium sulfate. Solvent was removed under reduced pressure and crude product was purified by silica gel column chromatography using a $\mathrm{MeOH} / \mathrm{CHCl}_{3}$ gradient, to afford $740 \mathrm{mg}$ of $\mathbf{4}$ as a brown solid. (Yield: 69\%). ${ }^{1} \mathrm{H}$ NMR (300 MHz, $\left.\mathrm{CDCl}_{3}\right): \delta=8.73(\mathrm{~d}, 1 \mathrm{H}, J 1.8), 8.55\left(\mathrm{dd}, 1 \mathrm{H},{ }^{3} J 4.5,{ }^{4} J 1.5\right), 7.76(\mathrm{dt}$, $\left.1 \mathrm{H}, J_{\mathrm{d}} 8.1, J_{\mathrm{t}} 1.5\right), 7.60\left(\mathrm{~d}, 1 \mathrm{H}, J_{\text {trans }} 15.9\right), 7.29(\mathrm{~m}, 1 \mathrm{H}), 6.47\left(\mathrm{~d}, 1 \mathrm{H}, J_{\text {trans }} 14.7\right), 6.04(\mathrm{br}, 1 \mathrm{H})$, 3.35 (m, 2H), 2.90 (s, br, 1H), 1.96 (m, 2H), 1.46 (m, 4H), 2.90-1.35 (10H, BH). ${ }^{13} \mathrm{C}$ NMR (100 $\left.\mathrm{MHz}, \mathrm{CDCl}_{3}\right): \delta=165.50,150.66 .149 .37,137.75,134.76,130.99,124.05,123.05,76.36,55.20$, 39.68, 36.79, 29.49, 27.63. HRMS (LC/MS, pos.): calcd. for $\mathrm{C}_{14} \mathrm{H}_{27} \mathrm{~B}_{10} \mathrm{~N}_{2} \mathrm{O}[\mathrm{M}+\mathrm{H}]^{+} 347.3134$, found: 347.0882 .

\subsubsection{The procedure for the synthesis of 5a-11}

1-(hydroxymethyl)-1,7-dicarbadodecaborane (5a). ${ }^{37}$ In a $250 \mathrm{~mL}$ 3-neck round bottom flask, $m$-carborane $(5.00 \mathrm{~g}, 34.7 \mathrm{mmol})$ was dissolved in 2:1 mixture of anhydrous benzene and $\mathrm{Et}_{2} \mathrm{O}(60 \mathrm{~mL})$. The solution was cooled to $0{ }^{\circ} \mathrm{C}$ in an ice bath while stirring, and $2.5 \mathrm{M} n$ butyllithium in hexane $(15.25 \mathrm{~mL}, 38.13 \mathrm{mmol})$ was added using an automated injection system 
at the rate of $0.5 \mathrm{ml} / \mathrm{min}$. The reaction mixture was allowed to stir for an hour while reach ambient temperature. It was then cooled to $0{ }^{\circ} \mathrm{C}$ again and paraformaldehyde $(1.46 \mathrm{~g}, 48.5$ mmol) was added all at once. The resulting suspension was allowed to stir overnight while slowly reaching ambient temperature. Reaction was quenched with $2 \mathrm{~N} \mathrm{HCl}$ solution $(50 \mathrm{~mL})$ and organic phase was extracted. EtOAc was used to extract the product $(3 \times 50 \mathrm{~mL})$ and all the organic extracts were combined and washed with DI water $(80 \mathrm{~mL})$, and brine $(80 \mathrm{~mL})$. Organic extracts were dried on $\mathrm{MgSO}_{4}$, filtered, concentrated, and purified using silica gel column chromatography using a gradient of EtOAc:hexane (20-75\%) to afford $3.59 \mathrm{~g}$ of $\mathbf{5 a}$ as a white powder (Yield: 59\%). $1.54 \mathrm{~g}$ of di-substituted product 1,7-(hydroxymethyl)-1,7dicarbadodecaborane (5b), and $560 \mathrm{mg}$ of $m$-carborane were also recovered. 5a: ${ }^{1} \mathrm{H}$ NMR (300 $\left.\mathrm{MHz}, \mathrm{CDCl}_{3}\right): \delta=3.81(\mathrm{~s}, 2 \mathrm{H}), 3.03(\mathrm{~s}, \mathrm{br}, 1 \mathrm{H}), 2.96(\mathrm{~s}, \mathrm{br}, 1 \mathrm{H}), 3.03-1.38(\mathrm{~m}, 10 \mathrm{H}, \mathrm{B}-\mathrm{H}) .{ }^{13} \mathrm{C}$ $\operatorname{NMR}\left(75.5 \mathrm{MHz}, \mathrm{CDCl}_{3}\right): \delta=65.59,55.18 .{ }^{11} \mathrm{~B}\left\{{ }^{1} \mathrm{H}\right\}(\mathrm{dc}) \mathrm{NMR}\left(96.3 \mathrm{MHz}, \mathrm{CDCl}_{3}\right): \delta=-4.80,-$ 6.72, -9.15, -10.79, -11.96, -13.37, -15.97.

1-(methyl triphenylmethyl ether)-1,7-dicarbadodecaborane (6). In a $250 \mathrm{~mL}$ 2-neck round bottom flask, 5 (3.48 g, $20 \mathrm{mmol})$ was dissolved in DCM (35 mL). Triphenylmethyl chloride $(6.12 \mathrm{~g}, 22 \mathrm{mmol})$ was added all at once and pyridine $(1.77 \mathrm{~mL}, 22 \mathrm{mmol})$ was added slowly while stirring at room temperature. The reaction was allowed to stir overnight. Reaction mixture was transferred to a separatory funnel, DI water $(40 \mathrm{~mL})$, brine $(2 \mathrm{~mL})$, and more DCM $(5 \mathrm{~mL})$ was added and organic phase was extracted. More DCM $(2 \times 10 \mathrm{~mL})$ was used to extract the product and all the organic extracts were combined and washed with DI water (40 mL), $1 \mathrm{M}$ $\mathrm{NH}_{4} \mathrm{Cl}(40 \mathrm{~mL})$ and brine $(50 \mathrm{~mL})$. Organic extracts were dried on $\mathrm{MgSO}_{4}$, filtered, concentrated, and purified using silica gel column chromatography using a gradient of DCM:hexane (5-10\%) and then switching to EtOAc:hexane (5-50\%) to afford $7.68 \mathrm{~g}$ of $\mathbf{6}$ as a 
white powder (Yield: $92 \%) .{ }^{1} \mathrm{H}$ NMR $\left(250 \mathrm{MHz}, \mathrm{CDCl}_{3}\right): \delta=7.44-7.40(\mathrm{~m}, 6 \mathrm{H}), 7.36-7.27(\mathrm{~m}$, 9H), $3.28(\mathrm{~s}, 2 \mathrm{H}), 2.94(\mathrm{~s}, 1 \mathrm{H}), 2.94-1.28(\mathrm{~m}, 10 \mathrm{H}, \mathrm{B}-\mathrm{H}) .{ }^{13} \mathrm{C} \mathrm{NMR}\left(62.9 \mathrm{MHz}, \mathrm{CDCl}_{3}\right): \delta=$ $143.46,128.86,128.31,127.65,86.88,65.76,55.23$.

1-(methyl triphenylmethyl ether)-7-(4-chlorobutyl)-1,7-dicarbadodecaborane (7). In a $250 \mathrm{~mL}$ 2-neck round bottom flask, 6 (4.58 g, $11 \mathrm{mmol})$ was dissolved in anhydrous THF (50 $\mathrm{mL}$ ). Solution was cooled to $0{ }^{\circ} \mathrm{C}$ in an ice bath while stirring and $2.5 \mathrm{M} n$-butyllithium in hexane $(4.84 \mathrm{~mL}, 12.1 \mathrm{mmol})$ was added using an automated injection system at the rate of 0.3 $\mathrm{mL} / \mathrm{min}$. The reaction mixture was allowed to stir for an hour while reach ambient temperature. It was then cooled to $-78{ }^{\circ} \mathrm{C}$ using acetone/dry-ice bath and add 1-chloro-4-iodobutane $(1.48 \mathrm{~mL}$, $12.1 \mathrm{mmol})$ was added $(0.3 \mathrm{~mL} / \mathrm{min})$ and allowed to stir for 2 hours while reaching ambient temperature. Reaction was quenched with $1 \mathrm{~N} \mathrm{NH}_{4} \mathrm{Cl}$ solution $(50 \mathrm{~mL})$ and organic phase was extracted. Hexane was used to extract the product $(2 \times 50 \mathrm{~mL})$ and all the organic extracts were combined and washed with brine $(70 \mathrm{~mL})$. Organic extracts were dried on $\mathrm{MgSO}_{4}$, filtered, and concentrated under reduced pressure to remove solvents and any remaining 1-chloro-4iodobutane. $5.57 \mathrm{~g}$ of 7 was recovered as a yellow oil (Yield: 100\%). ${ }^{1} \mathrm{H}$ NMR (300 MHz, $\left.\mathrm{CD}_{2} \mathrm{Cl}_{2}\right): \delta=7.44-7.40(\mathrm{~m}, 6 \mathrm{H}), 7.38-7.35(\mathrm{~m}, 6 \mathrm{H}), 7.32-7.28(\mathrm{~m}, 3 \mathrm{H}), 3.53(\mathrm{t}, J=6.5 \mathrm{~Hz}, 2 \mathrm{H})$, $3.29(\mathrm{~s}, 2 \mathrm{H}), 2.00(\mathrm{t}, J=8.4 \mathrm{~Hz}, 2 \mathrm{H}), 1.71(\mathrm{p}, J=7.0 \mathrm{~Hz}, 2 \mathrm{H}), 1.60-1.49(\mathrm{~m}, 2 \mathrm{H}), 3.50-1.00(\mathrm{~m}$, 10H, B-H). ${ }^{13} \mathrm{C} \mathrm{NMR}\left(75.5 \mathrm{MHz}, \mathrm{CD}_{2} \mathrm{Cl}_{2}\right): \delta=144.00,129.28,128.79,128.14,88.28,66.25$, $45.32,37.03,32.76,28.07$.

1-(hydroxymethyl)-7-(4-chlorobutyl)-1,7-dicarbadodecaborane (8). In a 250 mL 2neck round bottom flask, $7(5.72 \mathrm{~g}, 11 \mathrm{mmol})$ was dissolved in 1.5:1 mixture of $\mathrm{MeOH}$ and $\mathrm{CHCl}_{3}(50 \mathrm{~mL})$ and Concentrated $\mathrm{HCl}_{(\mathrm{aq})}(2 \mathrm{~mL})$ was added drop-wise while stirring at room 
temperature. The solution was stirred overnight and the following day, solvents were removed under reduced pressure and crude product was purified using silica gel column chromatography using a gradient of DCM:hexane (5-10\%) and then switching to EtOAc:hexane (5-50\%) to afford $2.54 \mathrm{~g}$ of $\mathbf{8}$ as yellow oil (Yield: $87 \%) .{ }^{1} \mathrm{H}$ NMR $\left(500 \mathrm{MHz}, \mathrm{CDCl}_{3}\right): \delta=3.80(\mathrm{~s}, 2 \mathrm{H}), 3.50$ $(\mathrm{t}, J 6.5,2 \mathrm{H}), 1.96(\mathrm{t}, J 8.8,2 \mathrm{H}), 1.83(\mathrm{~s}, 1 \mathrm{H}), 1.69(\mathrm{p}, J 7.0,2 \mathrm{H}), 1.56-1.52(\mathrm{~m}, 2 \mathrm{H}), 2.97-1.49$ (m, 10H, B-H). $\left.{ }^{13} \mathrm{C} \mathrm{NMR} \mathrm{(126} \mathrm{MHz,} \mathrm{CDCl}_{3}\right): \delta=77.21,75.96,65.65,44.58,36.51,32.20$, 27.54. HRMS (ESI, neg.) for $\mathrm{C}_{7} \mathrm{H}_{21} \mathrm{~B}_{10} \mathrm{ClO}$ : calcd $300.1950(\mathrm{M}+\mathrm{Cl})$, found 300.1781 .

1-(hydroxymethyl)-7-(4-azidobutyl)-1,7-dicarbadodecaborane (9). In a 25 mL 3-neck round bottom flask, 8 (667 mg, $2.52 \mathrm{mmol})$ was dissolved in DMF (8 mL). NaN 3 (327 mg, 4.04 $\mathrm{mmol})$, and catalytic amount of $\mathrm{NaI}(38 \mathrm{mg}, 0.25 \mathrm{mmol})$ was added and the mixture was refluxed at $70{ }^{\circ} \mathrm{C}$ overnight. The solution was cooled to room temperature, $\mathrm{Et}_{2} \mathrm{O}(20 \mathrm{~mL})$ was added and washed with $5 \% \mathrm{LiCl}_{(\mathrm{aq})}(3 \times 20 \mathrm{~mL})$. Combined aq phase were re-extracted with $\mathrm{Et} 2 \mathrm{O}(3 \times 20$ $\mathrm{mL}$ ), and all organic phase were combined and washed with $5 \% \mathrm{Na}_{2} \mathrm{~S}_{2} \mathrm{O}_{3(\mathrm{aq})}(20 \mathrm{~mL})$, and brine (20 mL). Organic phase was then dried on $\mathrm{MgSO}_{4}$, concentrated, and purified using silica gel column chromatography using a gradient of EtOAc:hexane (5-50\%) to afford $639 \mathrm{mg}$ of $\mathbf{9}$ as yellow oil (Yield: 99\%). ${ }^{1} \mathrm{H}$ NMR (500 MHz, $\left.\mathrm{CDCl}_{3}\right): \delta=3.79(\mathrm{~s}, 2 \mathrm{H}), 3.26(\mathrm{t}, J$ 6.5, 2H), 1.96 (t, $J$ 8.3, 2H), $1.88(\mathrm{~s}, \mathrm{br}, 1 \mathrm{H}), 1.63-1.47(\mathrm{~m}, 2 \mathrm{H}), 1.46-1.41(\mathrm{~m}, 2 \mathrm{H}), 2.96-1.63(\mathrm{~m}, 10 \mathrm{H}, \mathrm{B}-\mathrm{H})$. ${ }^{13} \mathrm{C} \mathrm{NMR}\left(126 \mathrm{MHz}, \mathrm{CDCl}_{3}\right): \delta=77.23,75.96,65.64,51.29,36.78,28.76,27.45 .{ }^{11} \mathrm{~B}\left\{{ }^{1} \mathrm{H}\right\}$ (dc) NMR (96.3 MHz, $\left.\mathrm{CDCl}_{3}\right): \delta=-6.45(1 \mathrm{~B}),-7.96(1 \mathrm{~B}),-11.06(4 \mathrm{~B}),-12.26(2 \mathrm{~B}),-14.41(2 \mathrm{~B})$. HRMS (ESI, neg.) for $\mathrm{C}_{7} \mathrm{H}_{21} \mathrm{~B}_{10} \mathrm{~N}_{3} \mathrm{O}$ : calcd $307.2348(\mathrm{M}+\mathrm{Cl})$, found 307.2177.

1-(hydroxymethyl)-7-(4-Aminobutyl)-1,7-dicarbadodecaborane (10). In a $100 \mathrm{~mL}$ 2neck round bottom flask equipped with a purge needle attached to a bubbler, 9 (1.79 g, 6.55 mmol) was dissolved in THF (40 mL). $\mathrm{PPh}_{3}(2.23 \mathrm{~g}, 8.52 \mathrm{mmol})$ was added all at once and the 
solution was stirred until gas stopped being generated. DI water $(0.3 \mathrm{~mL})$ was then added and the solution was stirred overnight. All solvents were removed under reduced pressure and purified using silica gel neutralized with pyridine (2\% pyridine in eluant). A gradient of $\mathrm{MeOH}: \mathrm{CHCl}_{3}$ (0-20\%) was used to afford $1.26 \mathrm{~g}$ of $\mathbf{1 0}$ as orange oil (Yield: $79 \%) .{ }^{1} \mathrm{H}$ NMR (500 MHz, $\left.\mathrm{CD}_{3} \mathrm{OD}\right): \delta=3.71(\mathrm{~s}, 2 \mathrm{H}), 2.62(\mathrm{t}, J 6.7,2 \mathrm{H}), 1.99(\mathrm{t}, J 8.0,2 \mathrm{H}), 1.45-1.37(\mathrm{~m}, 4 \mathrm{H}), 2.90-1.20$ (m, 10H, B-H). ${ }^{13} \mathrm{C}$ NMR (126 MHz, CD $\left.{ }_{3} \mathrm{OD}\right): \delta=80.39,78.18,66.49,42.79,38.87,33.65$, 29.41. ${ }^{11} \mathrm{~B}\left\{{ }^{1} \mathrm{H}\right\}$ (dc) NMR (96.3 MHz, CD $\left.3 \mathrm{OD}\right): \delta=-6.87,-7.89,-11.40,-14.18 . \mathrm{IR}\left(\mathrm{KBr}, \mathrm{cm}^{-1}\right)$ : v 3375 (br), 2926, 2594 (br), 803. HRMS (ESI, pos.) for $\mathrm{C}_{7} \mathrm{H}_{23} \mathrm{~B}_{10} \mathrm{NO}$ : calcd 246.2859 (M+H), found 246.2959.

\section{1-(hydroxymethyl)-7-(4'-(trans-3"'-(3'"'-pyridyl)acrylamido)butyl)-1,7-}

dicarbadodecaborane (11). In a $50 \mathrm{~mL}$ 2-neck round bottom flask 10 (472 mg, $1.92 \mathrm{mmol}$ ) and Hünig's base $(0.96 \mathrm{~mL}, 5.5 \mathrm{mmol})$ were dissolved in anhydrous THF $(10 \mathrm{~mL})$ and cooled to -78 ${ }^{\circ} \mathrm{C}$. In another $50 \mathrm{~mL}$ 2-neck round bottom flask attached to a vacuum line equipped with a secondary trap, trans-3-(3'-pyridyl)acrylic acid (250 mg, $1.67 \mathrm{mmol})$ was suspended in anhydrous DCM $(7 \mathrm{~mL})$ and DMF $\left(6.40 \mu \mathrm{L}, 8.35 \times 10^{-2} \mathrm{mmol}\right)$ was added as a catalyst. While stirring, thionyl chloride $(0.24 \mathrm{~mL}, 3.3 \mathrm{mmol})$ was added drop wise and the reaction mixture was allowed to stir for 2 hours at room temperature. The vessel was evacuated under reduced pressure to remove solvent and any gaseous byproducts. The crude trans-3-(3'-pyridyl)acryloyl chloride (PAC) was suspended in anhydrous THF $(10 \mathrm{~mL})$ and cooled to $-78{ }^{\circ} \mathrm{C}$ using an acetone/dry-ice bath while being vigorously stirred. The PAC mixture was then added drop wise to the reaction mixture containing $\mathbf{1 0}$. The resulting solution was allowed to stir overnight while slowly reaching ambient temperature. $1 \mathrm{M} \mathrm{NH}_{4} \mathrm{Cl}_{(\mathrm{aq})}(20 \mathrm{~mL})$ was added and stirred for 15 minutes. It was then transferred to a separatory funnel, $\mathrm{Et}_{2} \mathrm{O}(10 \mathrm{~mL})$ was added and allowed to 
sit for $30 \mathrm{~min}$. to get great separation before extracting the organic phase and again using $\mathrm{Et}_{2} \mathrm{O}$ (2 $\times 20 \mathrm{~mL}$ ). Combined organics were wash with $2 \mathrm{M} \mathrm{NaOH}(40 \mathrm{~mL})$, brine $(2 \times 40 \mathrm{~mL})$, dried on $\mathrm{MgSO}_{4}$, filtered, concentrated, and purified using silica gel column chromatography using a gradient of $\mathrm{MeOH}: \mathrm{CHCl}_{3}(0-10 \%)$ to afford $518 \mathrm{mg}$ of $\mathbf{1 1}$ as yellow foam (Yield: $\left.82 \%\right) .{ }^{1} \mathrm{H}$ NMR (500 MHz, $\left.\mathrm{CD}_{3} \mathrm{OD}\right): \delta=8.71(\mathrm{~s}, 1 \mathrm{H}), 8.52(\mathrm{~d}, J 4.0,1 \mathrm{H}), 8.05(\mathrm{~d}, J 8.0,1 \mathrm{H}), 7.55(\mathrm{~d}, J$ $15.5,1 \mathrm{H}), 7.48\left(\mathrm{dd},{ }^{3} J 8.0,{ }^{4} J 5.0,1 \mathrm{H}\right), 6.72(\mathrm{~d}, J 16.0,1 \mathrm{H}), 3.7(\mathrm{~s}, 2 \mathrm{H}), 3.28(\mathrm{t}, J 6.8,2 \mathrm{H}), 2.01$ (t, $J$ 8.2, 2H), $1.53-1.42(\mathrm{~m}, 4 \mathrm{H}), 2.80-1.60(\mathrm{~m}, 10 \mathrm{H}, \mathrm{B}-\mathrm{H}) .{ }^{13} \mathrm{C} \mathrm{NMR}\left(75.5 \mathrm{MHz}, \mathrm{CD}_{3} \mathrm{OD}\right): \delta=$ 167.67, 150.67, 149.64, 137.43, 136.36, 132.93, 125.58, 124.76, 79.46, 77.26, 65.63, 40.06, 37.73, 29.91, 28.48 pm. HRMS (ESI, neg) for $\mathrm{C}_{15} \mathrm{H}_{28} \mathrm{~B}_{10} \mathrm{~N}_{2} \mathrm{O}_{2}$ : calcd $375.3089(\mathrm{M}-\mathrm{H}$ ), found 375.3136 .

trans- $N$-(4'-phenylbutyl)-3-(3''-pyridyl)acrylamide (12). Compound 12 was prepared and purified similar to 4 using 4-phenylbutylamine $(1.00 \mathrm{~g}, 6.70 \mathrm{mmol})$ to afford $1.43 \mathrm{~g}$ of yellow foam (Yield: $76 \%) .{ }^{1} \mathrm{H}$ NMR $\left(250 \mathrm{MHz}, \mathrm{CDCl}_{3}\right): \delta=8.72(\mathrm{~d}, 1 \mathrm{H}, J 2.0), 8.53\left(\mathrm{dd}, 1 \mathrm{H},{ }^{3} J\right.$ $\left.4.8,{ }^{4} J 1.5\right), 7.75\left(\mathrm{dt}, 1 \mathrm{H}, J_{\mathrm{d}} 8.0, J_{\mathrm{t}} 1.9\right), 7.59\left(\mathrm{~d}, 1 \mathrm{H}, J_{\text {trans }} 15.5\right), 7.3-7.22(\mathrm{~m}, 3 \mathrm{H}), 7.2-7.14$ $(\mathrm{m}, 3 \mathrm{H}), 6.48\left(\mathrm{~d}, 1 \mathrm{H}, J_{\text {trans }} 15.7\right), 6.14(\mathrm{t}, \mathrm{br}, 1 \mathrm{H}, J 10.5), 3.40(\mathrm{q}, 2 \mathrm{H}, J 6.5), 2.64$ (t, 2H, J 7.2), 1.76-1.54 (m, 4H). ${ }^{13} \mathrm{C}$ NMR (62.9 MHz, $\left.\mathrm{CDCl}_{3}\right): \delta=165.49,150.35,149.14,137.32,134.84$, 131.15, 128.69, 128.65, 126.15, 124.05, 123.45, 39.98, 35.77, 29.47, 28.99. HRMS (TIS, pos.): calcd. for $\mathrm{NaC}_{18} \mathrm{H}_{20} \mathrm{~N}_{2} \mathrm{O}[\mathrm{M}+\mathrm{Na}]^{+}$303.1473, found: 303.2519 .

4-iodobutyronitrile (13). ${ }^{55} \mathrm{In}$ a $500 \mathrm{~mL}$ 2-neck round bottom flask, 4-chlorobutyronitrile $(10.0 \mathrm{~g}, 9.26 \mathrm{~mL}, 96.6 \mathrm{mmol})$ was dissolved in anhydrous acetone $(115 \mathrm{~mL})$ and $\mathrm{NaI}(28.95 \mathrm{~g}$, $193.1 \mathrm{mmol}$ ) was added. The solution was refluxed for 2 days. Solvent was evacuated under reduced pressure. The crude product was redissolved in EtOAc $(80 \mathrm{~mL})$ and $\mathrm{H}_{2} \mathrm{O}(80 \mathrm{~mL})$. The 
organic phase was extracted and washed with $5 \%$ solution of $\mathrm{Na}_{2} \mathrm{~S}_{2} \mathrm{O}_{3}(60 \mathrm{~mL})$, saturated $\mathrm{NaHCO}_{3}(60 \mathrm{~mL})$, and brine solution $(60 \mathrm{~mL})$. The organic phase was dried over anhydrous magnesium sulfate. Solvent was removed under reduced pressure to afford $17.54 \mathrm{~g}$ of $\mathbf{1 3}$ as a light yellow oil (Yield: 96\%). ${ }^{1} \mathrm{H}$ NMR (300 MHz, $\left.\mathrm{CDCl}_{3}\right): \delta=3.29(\mathrm{t}, J 6.5,2 \mathrm{H}), 2.53(\mathrm{t}, J$ 6.9, 2H), 2.14 (p, J 6.7, 2H). $\left.{ }^{13} \mathrm{C} \mathrm{NMR} \mathrm{(75.5} \mathrm{MHz,} \mathrm{CDCl}_{3}\right): \delta=118.58,29.108,18.70,3.20$.

4-morpholinobutanenitrile (14). ${ }^{56,58}$ In a $250 \mathrm{~mL} 3$-neck round bottom flask, morpholine (6.31 g, $6.25 \mathrm{~mL}, 72.4 \mathrm{mmol})$, 4-chlorobutyronitrile (5.00 g, $4.63 \mathrm{ml}, 48.3 \mathrm{mmol})$, $\mathrm{K} 2 \mathrm{CO} 3(7.34 \mathrm{~g}, 53.1 \mathrm{mmol})$, and $\mathrm{KI}(0.80 \mathrm{~g}, 4.8 \mathrm{mmol})$ were added to 1-butanol $(50 \mathrm{~mL})$ and the reaction mixture was refluxed for 2 days. The suspension was filtered and the filtrate was concentrated under reduced pressure. $2 \mathrm{~N} \mathrm{HCl}$ solution $(50 \mathrm{~mL})$ was added to the crude product and stirred for one hour. The solution was washed with $\mathrm{Et}_{2} \mathrm{O}(3 \times 50 \mathrm{~mL})$. The $\mathrm{pH}$ was adjusted to 10 by gradually adding $10 \mathrm{M} \mathrm{NaOH}$ solution $(\sim 10 \mathrm{~mL})$ and the product was extracted with EtOAc $(3 \times 50 \mathrm{~mL})$. The combined organics were dried over anhydrous magnesium sulfate. Solvent was removed under reduced pressure to afford $6.01 \mathrm{~g}$ of $\mathbf{1 4}$ as a light yellow oil (Yield: 83\%). ${ }^{1} \mathrm{H}$ NMR (500 MHz, $\mathrm{CDCl}_{3}$ ) $): \delta=3.68(\mathrm{t}, 4 \mathrm{H}, J 4.5), 2.45-2.41(\mathrm{~m}, 8 \mathrm{H}), 1.81(\mathrm{p}, 2 \mathrm{H}, J$ 6.9). ${ }^{13} \mathrm{C}$ NMR $\left(125.8 \mathrm{MHz}, \mathrm{CDCl}_{3}\right): \delta=119.98,67.17,56.91,53.79,22.65,15.12$. HRMS (ICPMS, pos.): calcd. for $\mathrm{C}_{8} \mathrm{H}_{15} \mathrm{~N}_{2} \mathrm{O}[\mathrm{M}+\mathrm{H}]^{+} 155.1185$, found: 155.2357 .

4-morpholinobutan-1-amine (15). ${ }^{56}$ In a $50 \mathrm{~mL}$ 2-neck round bottom flask, 14 (0.50 g, $0.50 \mathrm{~mL}, 3.3 \mathrm{mmol})$ was dissolved in $\mathrm{Et}_{2} \mathrm{O}(10 \mathrm{~mL})$ and cooled to $0{ }^{\circ} \mathrm{C}$ in an ice bath. $\mathrm{LiAlH}_{4}$ (247 mg, $6.50 \mathrm{mmol}$ ) was dissolved in $\mathrm{Et}_{2} \mathrm{O}(12 \mathrm{~mL})$ and cooled to $0{ }^{\circ} \mathrm{C}$ in an ice bath and added to the reaction mixture drop wise. The reaction was allowed to stir for 3 hours while reaching ambient temperature. The crude product was purified using the Fieser work-up to afford $357 \mathrm{mg}$ 
of $\mathbf{1 5}$ as a yellow oil (Yield: 69.5\%). ${ }^{1} \mathrm{H} \mathrm{NMR}\left(500 \mathrm{MHz}, \mathrm{CDCl}_{3}\right): \delta=3.68(\mathrm{t}, 4 \mathrm{H}, J 4.7), 2.68(\mathrm{t}$, $2 \mathrm{H}, J$ 6.8), $2.40(\mathrm{~s}, \mathrm{br}, 4 \mathrm{H}), 2.31(\mathrm{t}, 2 \mathrm{H}, J 7.2), 1.78(\mathrm{~s}, \mathrm{br}, 2 \mathrm{H}), 1.53-1.41(\mathrm{~m}, 4 \mathrm{H}) .{ }^{13} \mathrm{C} \mathrm{NMR}$ $\left(125.8 \mathrm{MHz}, \mathrm{CDCl}_{3}\right): \delta=67.26,59.18,54.03,42.33,31.84,24.25$.

trans- $N$-(4'-(morpholinobutyl)-3-(3''-pyridyl)acrylamide (16). Compound 16 was prepared and purified similar to 4 using $15(341 \mathrm{mg}, 2.15 \mathrm{mmol})$ to afford $67 \mathrm{mg}$ of dark orange solid (Yield: $12 \%) .{ }^{1} \mathrm{H}$ NMR $\left(500 \mathrm{MHz}, \mathrm{CDCl}_{3}\right): \delta=8.73(\mathrm{~d}, 1 \mathrm{H}, J 1.5), 8.55\left(\mathrm{dd}, 1 \mathrm{H},{ }^{3} J 5.0,{ }^{4} J\right.$ 1.3), $7.78\left(\mathrm{dt}, 1 \mathrm{H}, J_{\mathrm{d}} 10.0, J_{\mathrm{t}} 1.7\right), 7.60\left(\mathrm{~d}, 1 \mathrm{H}, J_{\text {trans }} 15.5\right), 7.30\left(\mathrm{dd}, 1 \mathrm{H},{ }^{3} J 7.8,{ }^{4} J 5.0\right), 6.66(\mathrm{t}, \mathrm{br}$, $1 \mathrm{H}, J$ 4.5), $6.52\left(\mathrm{~d}, 1 \mathrm{H}, J_{\text {trans }} 16.0\right), 3.79(\mathrm{t}, 4 \mathrm{H}, J 4.5), 3.41(\mathrm{q}, 2 \mathrm{H}, J 6.2), 2.6(\mathrm{~s}, \mathrm{br}, 4 \mathrm{H}), 2.51(\mathrm{t}$, $2 \mathrm{H}, J$ 7.0), 1.70-1.61 (m, 4H). ${ }^{13} \mathrm{C} \mathrm{NMR}\left(125.8 \mathrm{MHz}, \mathrm{CDCl}_{3}\right): \delta=165.58,150.52,149.41$, $137.42,134.70,131.12,124.06,123.39,66.48,58.21,53.55,39.41,27.29,23.40$.

4-(piperidin-1-yl)butanenitrile (17). ${ }^{56,58}$ Compound 17 was prepared and purified similar to 14 using piperidine $(0.91 \mathrm{~mL}, 9.2 \mathrm{mmol})$ to afford $777 \mathrm{mg}$ of orange oil (Yield: $83 \%)$. ${ }^{1} \mathrm{H}$ NMR (250 MHz, $\left.\mathrm{CDCl}_{3}\right): \delta=2.39(\mathrm{t}, 2 \mathrm{H}, J$ 7.3), $2.37(\mathrm{t}, 2 \mathrm{H}, J$ 6.9), $2.34(\mathrm{t}, 4 \mathrm{H}, J$ 5.5), 1.79 $\left(\mathrm{P}, 2 \mathrm{H}, J\right.$ 7.0), $1.54\left(\mathrm{P}, 4 \mathrm{H}, J\right.$ 5.5), 1.45-1.36 (m, 2H). ${ }^{13} \mathrm{C} \mathrm{NMR}\left(62.9 \mathrm{MHz}, \mathrm{CDCl}_{3}\right): \delta=120.19$, 57.44, 54.82, 26.26, 24.68, 23.22, 15.28. HRMS (ICP-MS, pos.): calcd. for $\mathrm{C}_{9} \mathrm{H}_{17} \mathrm{~N}_{2}[\mathrm{M}+\mathrm{H}]^{+}$ 153.1386, found: 153.2230 .

4-(piperidin-1-yl)butan-1-amine (18). ${ }^{56,59}$ Compound 18 was prepared and purified similar to 15 using 17 (4.44 g, $4.77 \mathrm{~mL}, 29.2 \mathrm{mmol}$ ) to afford $3.82 \mathrm{~g}$ of yellow oil (Yield: 84\%). ${ }^{1} \mathrm{H} \mathrm{NMR}\left(500 \mathrm{MHz}, \mathrm{CDCl}_{3}\right): \delta=2.67(\mathrm{t}, 2 \mathrm{H}, J 7.0), 2.33(\mathrm{~s}, 4 \mathrm{H}), 2.25(\mathrm{t}, 2 \mathrm{H}, J 7.0), 1.54(\mathrm{P}, 4 \mathrm{H}$, $J$ 6.0), $1.51-1.46(\mathrm{~m}, 2 \mathrm{H}), 1.44-1.38(\mathrm{~m}, 4 \mathrm{H}) .{ }^{13} \mathrm{C} \mathrm{NMR}\left(125.8 \mathrm{MHz}, \mathrm{CDCl}_{3}\right): \delta=59.64,54.91$, $42.44,32.23,26.27,24.77,24.66$. 
trans- $N$-(4'-(piperidin-1-yl)butyl)-3-(3'’-pyridyl)acrylamide (19). Compound 19 was prepared and purified similar to 4 using 18 (909 mg, $5.82 \mathrm{mmol})$ to afford $643 \mathrm{mg}$ of yellow solid (Yield: 38\%). ${ }^{1} \mathrm{H}$ NMR (300 MHz, $\left.\mathrm{CDCl}_{3}\right): \delta=8.38(\mathrm{~s}, 1 \mathrm{H}), 8.20(\mathrm{~d}, 1 \mathrm{H}, J 3.9), 7.42(\mathrm{~d}$, $1 \mathrm{H}, J$ 7.8), $7.26(\mathrm{~s}, 1 \mathrm{H}), 7.25\left(\mathrm{~d}, 1 \mathrm{H}, J_{\text {trans }} 15.6\right), 7.26-7.22(\mathrm{~m}, 1 \mathrm{H}), 6.24\left(\mathrm{~d}, 1 \mathrm{H}, J_{\text {trans }} 15.6\right)$, 3.36-3.34 (m, 2H), $2.43(\mathrm{~s}, 4 \mathrm{H}), 2.36(\mathrm{t}, 2 \mathrm{H}, J 6.6), 1.64-1.60(\mathrm{~m}, 8 \mathrm{H}), 1.46-1.44(\mathrm{~m}, 2 \mathrm{H}) .{ }^{13} \mathrm{C}$ $\operatorname{NMR}\left(75.5 \mathrm{MHz}, \mathrm{CDCl}_{3}\right): \delta=165.43,150.38,149.33,136.80,134.46,131.15,123.91,123.73$, 58.54, 54.53, 39.68, 27.44, 25.78, 24.40, 24.30. 


\section{Chapter 3 : Prodrugs with Short Clickable Cleavable Linkers}

\subsection{Introduction}

Worldwide, there exists a tremendous unmet need for more efficacious and affordable treatments for nearly every type of cancer. The need for new treatments is even greater for advanced and/or recurrent cancers.

A limitation of all small molecule anticancer agents is toxicity towards healthy cells. The development of such agents is necessarily a compromise between maximizing a drug's biological activity with its absorption, distribution, metabolism, and excretion (ADME). In order to achieve a clinically meaningful therapeutic effect, most anticancer agents must be administered at, or near, their maximum tolerated dose (MTD). Unfortunately, the anticancer agents used today in clinics possess insufficient therapeutic windows which are necessary to achieve complete disease remission in all patients. Improvements to the therapeutic indices of anticancer agents will come from either: 1) increases in agent potency which will tend to decrease the minimum effective dose required, or 2) increase in agent selectivity for cancer, which should improve MTD. Ideally, both the potency and selectivity of an agent could be improved. One possible route toward these improvements is through the conjugation of an anticancer agent to a peptide or antibody vector associated with cancer (PDC, or ADC, resp.). ${ }^{60-64}$ In principle, PDCs or ADCs promise to decouple the biological activity of an agent from the ADME of the free molecule, facilitating the targeted delivery of drugs to cancer cells. There are several additional potential advantages to using such conjugates, including: increasing the solubility of poorly 
soluble molecules, decreasing systemic toxicity, increasing drug circulation time, and controlling the rate of drug delivery. ${ }^{60-64}$

There are currently several dozen clinical trials for PDCs/ADCs for the treatment of cancer and there is an increasing interest in the development of such molecularly targeted drug delivery systems. ${ }^{65,66}$ There is also a recognized need for the development of personalized medicine where treatment is tailored to the disease of an individual patient. The use of a PDC/ADC which bears a vector associated with antigens expressed by an individual patient's tumor promises to dramatically improve treatment efficacy. ${ }^{60-64}$

PDCs/ADCs each consist of three general components: a peptide or antibody targeting vector, a potent cytotoxic agent, and a linker which connects the vector with the cytotoxic agent. The selection of an agent for inclusion in a PDC/ADC is of paramount importance. The number of molecules of a cytotoxic agent that are necessary to kill a cancer cell must be less than (ideally much less than) the number able to be delivered by the targeting vector, such as the number of surface receptor binding sites expressed on that cell. ${ }^{60-64}$ For antibodies, this number is often assumed to be below $10^{5}$ and therefore requires the cytotoxic agent to exhibit cell killing effects at low nanomolar concentrations; ideally picomolar. Such concentrations are several orders of magnitude below most of the drugs used to treat cancer today and one reason for the failure of early ADCs.

While in circulation, the linker must stably bind the cytotoxic agent to the antibody under physiological conditions for several days, while also facilitating the cleavage of the free drug once internalized in a targeted cell.

A new and promising target for the treatment of cancer is nicotinamide phosphoribosyltransferase (Nampt; aka visfatin, PBEF). Nampt is the first and rate limiting 
enzyme in the mammalian $\mathrm{NAD}^{+}$recycling pathway, catalyzing the conversion of nicotinamide to nicotinamide mononucleotide. Over the past seven years, Nampt activity has been revealed to be highly implicated with many diseases, including cancer. ${ }^{4,16,67}$ Overexpression of Nampt increases SIRT activity. ${ }^{9}$ SIRT and PARP, two $\mathrm{NAD}^{+}$dependent enzymes, obtain $\mathrm{NAD}^{+}$ primarily from the Nampt controlled recycling pathway. ${ }^{9}$ Nampt has been shown to be upregulated in many/most cancers. ${ }^{42-49}$

A small molecule discovered through compound screening designated FK866/APO866 was the first known potent inhibitor of Nampt and has been investigated in a number of Phase I/II clinical trials against several cancers. ${ }^{14}$ While treatment of patients with the drug was determined to be well tolerated and safe (Phase II recommended dose: CIV infusion 0.126 $\mathrm{mg} / \mathrm{m}^{2} / \mathrm{hr}$ for 4 consecutive days), the dose limiting toxicity (thrombocytopenia) prevented the delivery of an efficacious dose. ${ }^{52}$ FK866 has been shown to produce no direct cytotoxic effect on cells. Instead, cancer cells treated with FK866 deplete their reserves of $\mathrm{NAD}^{+}$, inducing apoptosis, ${ }^{14}$ while the drug exhibits minimal toxic effects on most normal cells. ${ }^{15,51}$ One consequence of this mechanism is that the cells must be exposed to Nampt inhibitor for a sufficient amount of time for the depletion of $\mathrm{NAD}^{+}$to occur, which typically requires 1-3 days in vitro. ${ }^{14}$

Our research group has recently reported a new family of carborane-containing Nampt inhibitors which exhibit up to 10-fold higher activities than FK866 in several cancer cell lines in vitro and an approximately 100-fold greater inhibition of Nampt (Figure 1A). ${ }^{24}$ Exhibiting subnanomolar $\mathrm{IC}_{50}$ concentrations in cancer cells in vitro, these molecules are the most potent inhibitors of Nampt reported to date. 
Recently, the sub-nanomolar potency of our agent MC4-PPEA was observed and reported by an independent research group. ${ }^{53}$ In addition to the published results, the Nampt inhibitors developed in our laboratories have been shown to exhibit increased antiproliferative and antimigratory effects over FK866 in wound healing assays against the PC3 prostate cancer cell line which is currently pending publication.

While Nampt inhibitors exhibit extremely high potency in vitro, the systemic toxicity observed during the APO866 clinical trials render that drug useless for the treatment of cancer alone. Furthermore, the duration of drug exposure required to treat cells (to allow NAD ${ }^{+}$ depletion) necessitates a long infusion over a period of 96 hours and thus necessitates extensive hospitalization and expense. However, Nampt as a target for treating cancer remains appealing for several reasons: Most cancers overexpress Nampt, and this overexpression is highest in aggressive and refractory cancers. ${ }^{16,50}$ Nampt overexpression is predictive of poor response to the treatment of various cancers, ${ }^{16,50}$ including breast cancer. ${ }^{68}$ Most healthy cells do not utilize Nampt. ${ }^{15,51}$ Given sufficient exposure time, Nampt inhibitors are exceptionally potent when compared with modern small molecule anticancer agents. ${ }^{14,24}$

We have recently reported a new derivative of our Nampt inhibitor MC4-PPEA (4), bearing a hydroxymethyl moiety (11) attached to the carborane cluster. In vitro assays reveal the presence of the hydroxymethyl group does not greatly diminish the activity of this new molecule and provides a convenient linkage for covalent attachment through carbonates, carbamates, and esters.

The extracellular environment of cancer cells are acidic likely due to secretion of lactate caused by anaerobic glycolysis and higher levels of carbonic acid due to dilution of $\mathrm{CO}_{2}$ generated by pentose phosphate pathway. ${ }^{69}$ This unique property allows for utilization of 
cleavable linkers that are acid sensitive. There are many functional groups that are catalyzed in acidic environments to undergo hydrolysis. By using such groups, it is possible to attach drug molecules to targeting agents such as proteins or antibodies and selectively release the drug at the tumor site.

In the present study, we describe the synthesis of three prodrugs of $\mathbf{2 8 ,} \mathbf{3 0}$, and $\mathbf{3 3}$ bearing a terminal azide moiety for attachment to vectors through the facile click-chemistry cycloaddition reaction. This facilitates the conjugation under mild conditions, while protecting the integrity of the cleavable linker.

\subsection{Results and Discussions}

\subsubsection{Clickable fluorophore}

Stability of the prodrugs were monitored using HPLC with UV-Vis and fluorescence detector. The prodrug stability was tested in buffer with $\mathrm{pH}$ of 5.5, 7.5, and 9.5, as well as horse serum, all at normothermia $\left(37^{\circ} \mathrm{C}\right)$. In order to attach a fluorophore, a short polyethylene glycol (PEG) linker was modified with an amine at the terminal end and an alkyne at the other. This linker was used to react with dansyl chloride which was commercially available to make compound 23 (Scheme 3.1). Using click type chemistry, the versatile fluorophore can covalently bond with any azide containing prodrug, very quickly, and under very mild conditions at high yields. 
Scheme 3.1 - Clickable Fluorophore
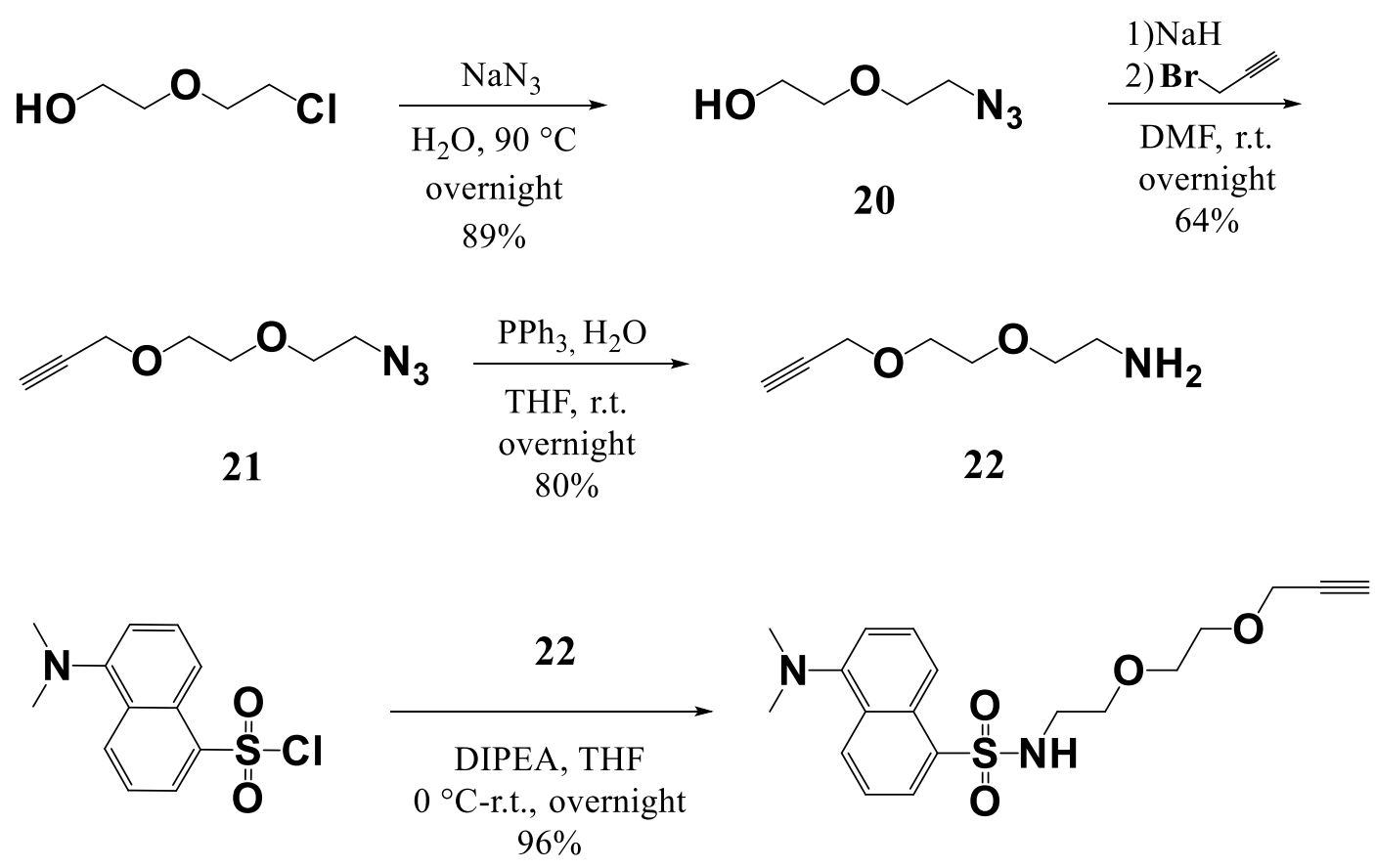

23

\subsubsection{Hydrolysable linkers}

Known hydrolysable functional groups that could be further modified with polyethylene glycols (PEGs) to assist with solubility were used. Ester, carbonate, and carbamate have been previously utilized as hydrolysable part of prodrugs.$^{70}$ Herein we propose three short linkers with acid chloride or chloroformate at one end and an azide group at the other.

4-Nitrophenyl chloroformate was commercially available and very reactive toward alcohols. Post reacting with the hydroxyl group on hm-MC4-PPEA, 4-Nitrophenyl carbonate (27) was formed. These groups are susceptible to nucleophilic attack and the 4-nitrophenolate byproduct is stabilized through resonance of the aromatic ring and the electron donation of the nitro group in the para position through resonance. Most nucleophiles such as those with a 
primary amine or alcohol can react with the 4-nitrophenyl carbonate to make the corresponding carbonate linkage. In this study compound 7 was used to make the corresponding carbamate linkage (28) (Scheme 3.2).

Scheme 3.2 - Synthesis of the carbamate prodrug 28

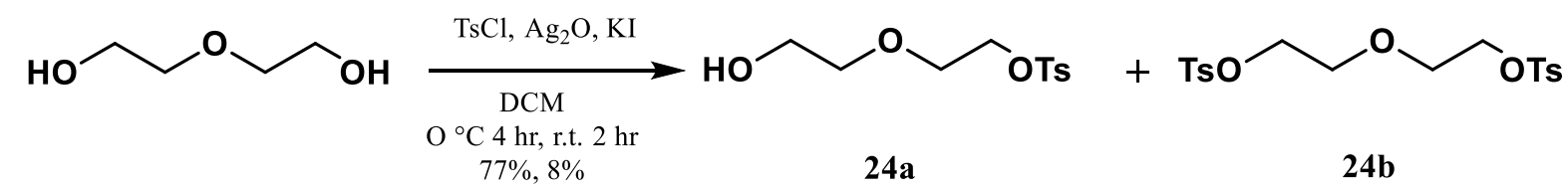

5b

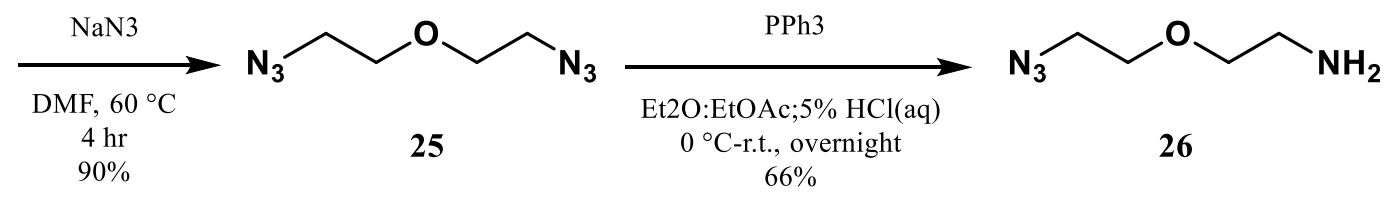

11

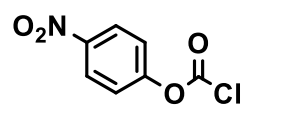

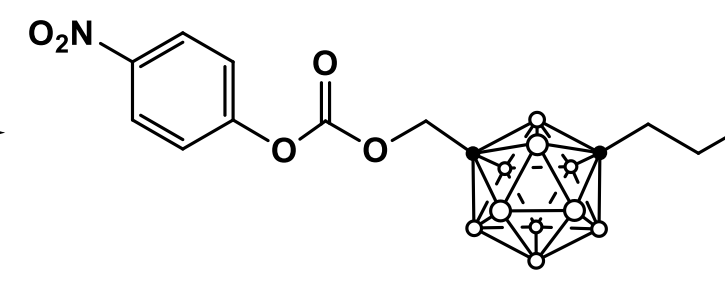<smiles>CCCNC(=O)/C=C/c1cccnc1</smiles>

Pyridine, THF

$0{ }^{\circ} \mathrm{C}$-r.t., overnight $88 \%$

27

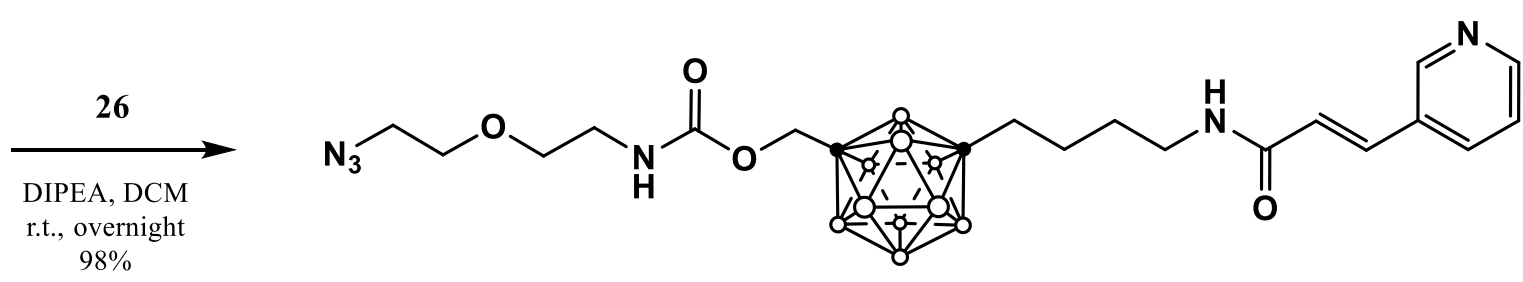

The carbonate prodrug (30) was prepared by treating the drug with commercially available 2-chloroethyl chloroformate and substituting the chloro group with azide in a $\mathrm{S}_{\mathrm{N}} 2$ type reaction. The synthetic process is demonstrated in Scheme 3.3. Chloroformate linkers with 
various lengths can be synthesized using phosgene and PEGs with terminal halides. For stability purposes, the short linker was conveniently made using available material.

Scheme 3.3 - Synthesis of the carbonate prodrug 30

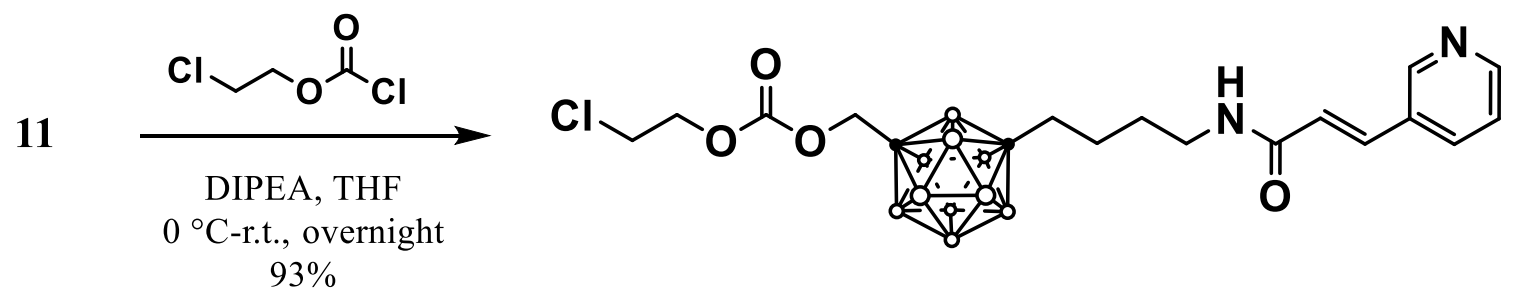

29

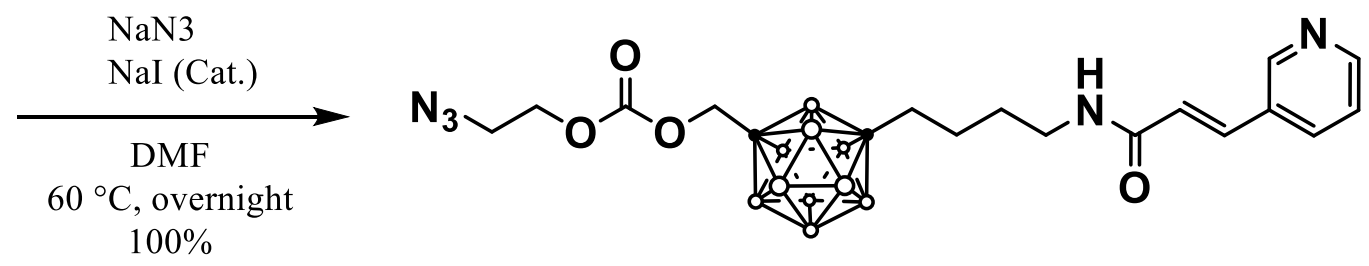

30

To form the ester prodrug (33), 20 was first treated with Jones Reagent. Post oxidation, the newly formed carboxylic acid (31) was treated with thionyl chloride to make the acid chloride (32). The acid chloride can then react with the hydroxyl group present on the drug to form 33 (Scheme 3.4). To increase the solubility of the prodrug, any length PEG can be chosen to make this type of linkage. 
Scheme 3.4 - Synthesis of the ester prodrug 33
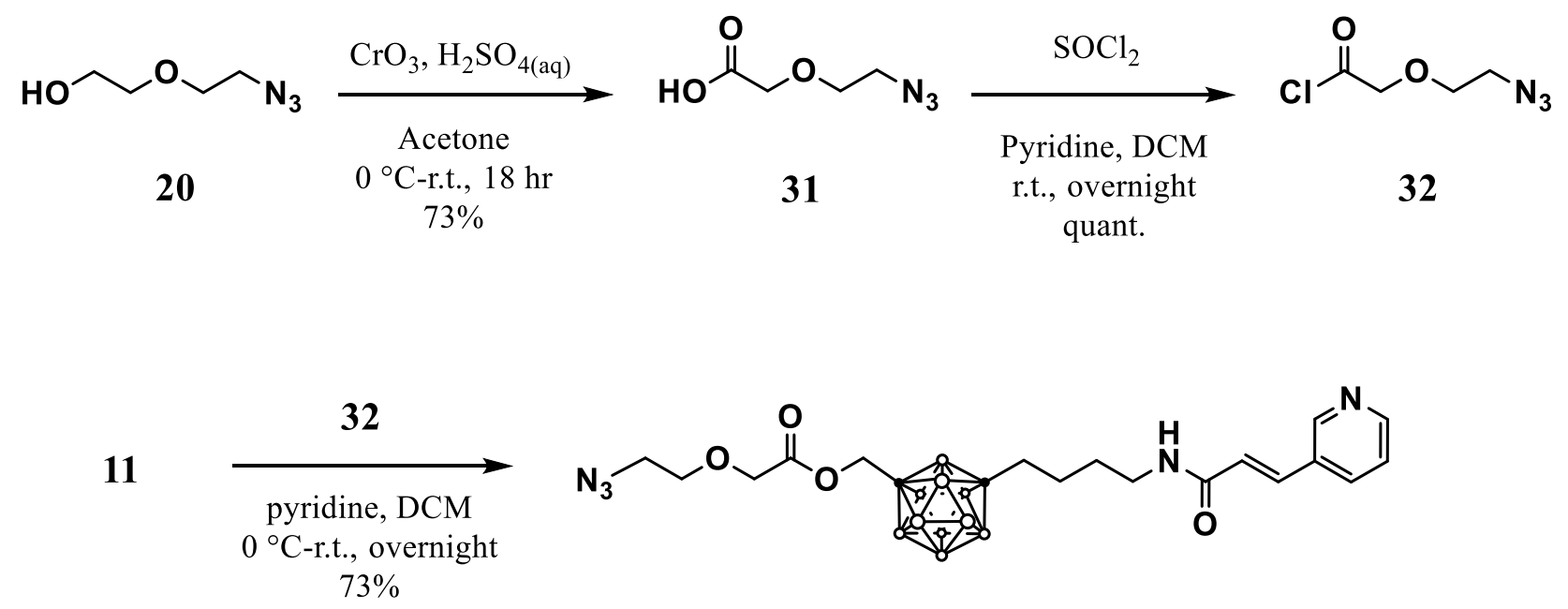

33

The azide containing prodrugs $\mathbf{2 8}, \mathbf{3 0}, \mathbf{3 3}$ were then covalently bound to the alkyne containing fluorophore $\mathbf{2 3}$ through click type chemistry. Anhydrous DMSO was degassed by bubbling nitrogen gas through the solvent to minimize the presence of molecular oxygen. This will help reduce the oxidation of the metal catalyst. Copper iodide was used as the catalyst and $N, N, N^{\prime}, N^{\prime}, N^{\prime \prime}$-pentamethyldiethylenetriamine (PMDETA) was used as a tridentate chelating ligand to stabilize copper(I) and prevent it from oxidation. DIPEA was used as the base and the reaction mixture was sonicated for an hour at room temperature. The clicked products 34-36 were synthesized under the same condition described in high yields (Scheme 3.5). 
Scheme 3.5 - Prodrug linked to fluorophore through Click Chemistry ${ }^{a}$

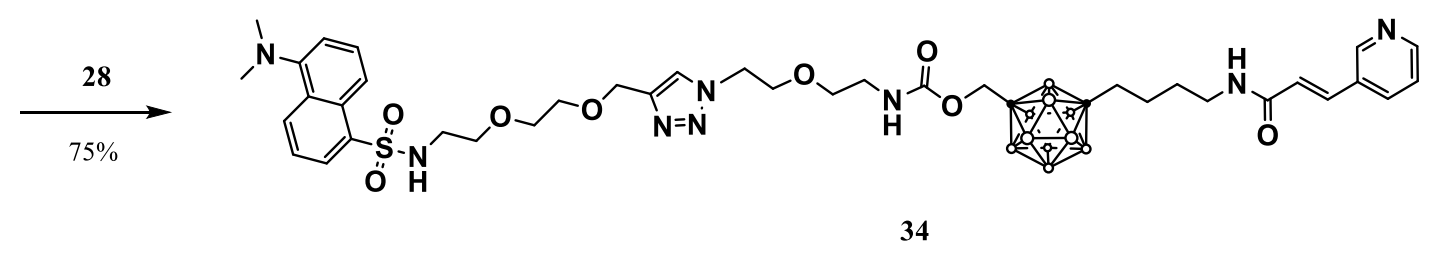

23
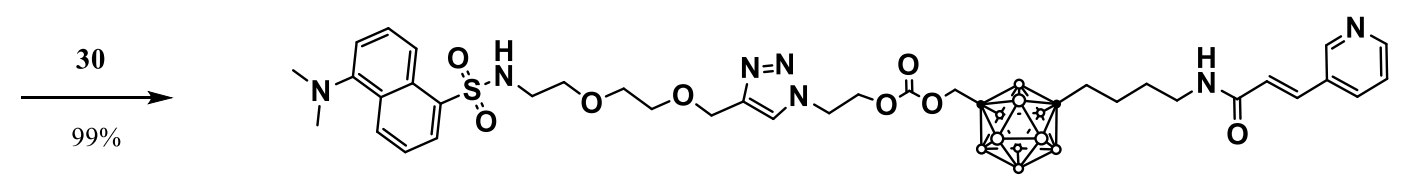

35
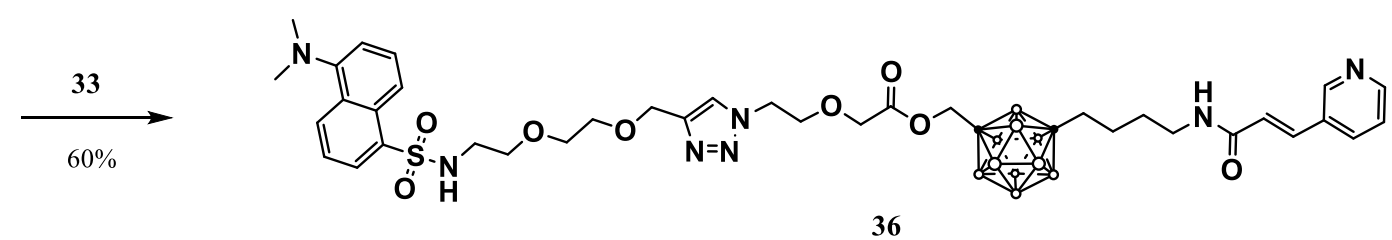

${ }^{a}$ Reagents and conditions (All three reactions follow the same procedure): DIPEA, PMDETA, $\mathrm{CuI}$, DMSO, sonicate for $1 \mathrm{hr}$ at room temperature.

\subsubsection{Linker stability test}

Compounds 34-36 were tested for stability in Phosphate buffered saline (PBS) as well as horse serum. All tests were conducted at normal human body temperature of $37^{\circ} \mathrm{C}$. The $\mathrm{pH}$ of the PBS buffer was adjusted so that an acidic $(\mathrm{pH}=5.5)$, a slightly alkali buffer similar to that of human blood ( $\mathrm{pH}=7.4)$, as well as a basic buffer $(\mathrm{pH}=9.5)$ were utilized. A low concentration solution of 34-36 were prepared in acetonitrile and was further diluted so that a 50:50 solution of 
acetonitrile to PBS buffer was achieved. To prepare the horse serum samples, $5 \mu \mathrm{L}$ of the low concentration of the same prodrugs were dissolved in $200 \mu \mathrm{L}$ of horse serum and sonicated. There were no visible precipitation in the horse serum in presence of $2.4 \%$ acetonitrile. Horse serum contains two main esterase enzymes: choline esterase, and ali-esterase. ${ }^{71}$ Ali-esterase main purpose is the hydrolysis of simple aliphatic esters so we believe that it may be the main enzyme responsible for the hydrolysis of our linkers. ${ }^{71}$ Further testing is needed to confirm this theory.

The samples were injected into a HPLC system equipped with an UV-Vis detector as well as fluorescence detector. The retention time and the percent area of the peaks were recorded. The retention time of the free drug was measured using a sample containing pure hmMC4-PPEA drug (11). This sample had a single UV peak while the prodrug was detected with both UV and fluorescence detector. The cleavage of the drug resulted in the appearance of two new peaks. The peak for free drug detected by the UV-Vis detector at the known retention time, and the liberated fluorophore detected by the UV-Vis as well as the fluorescence detector. The percent concentration of the prodrugs vs time were plotted and demonstrated in Figure 3.1,Figure 3.2, andFigure 3.3. 


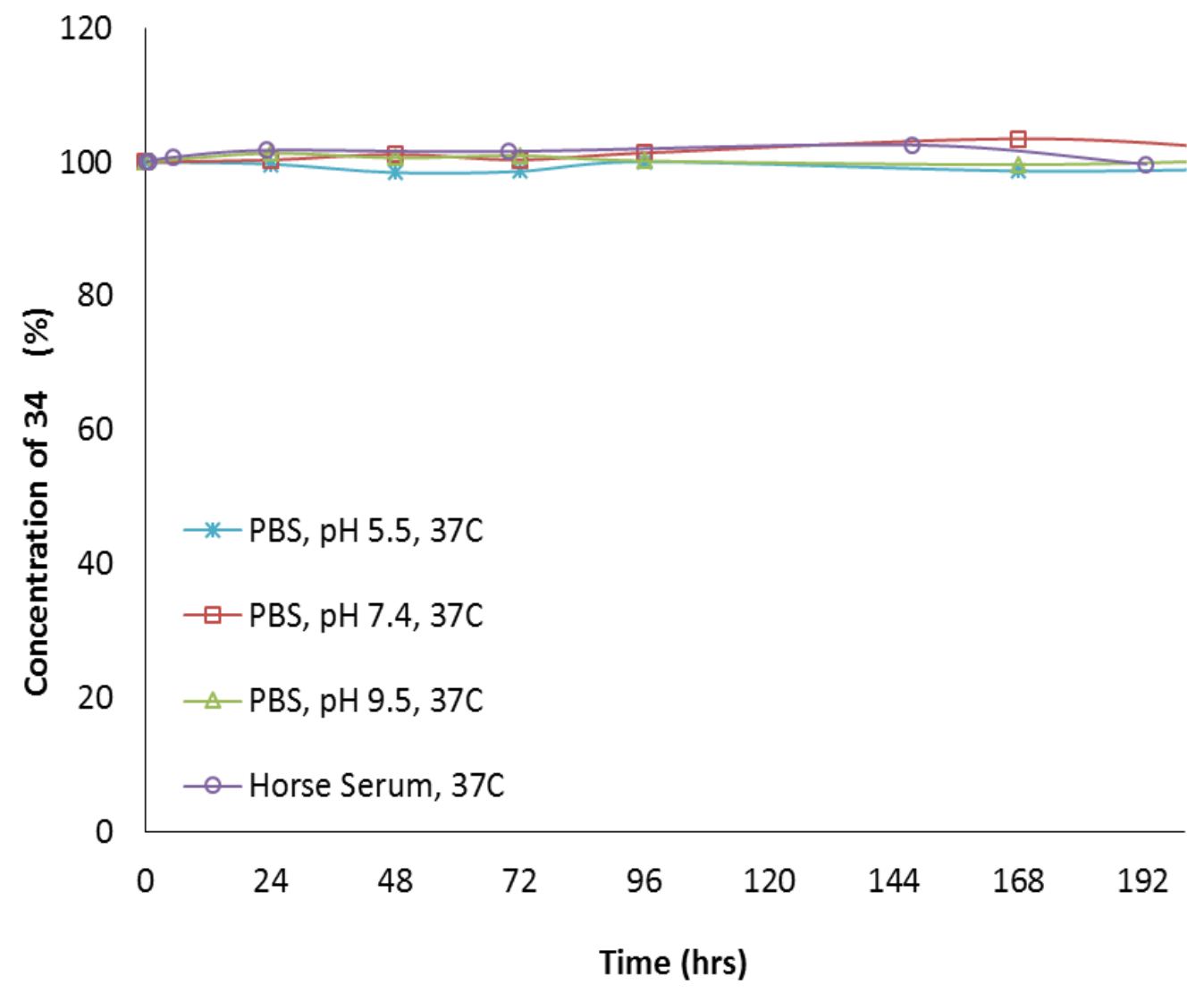

Figure 3.1 - Time dependent cleavage of $\mathbf{3 4}$ under various conditions. 


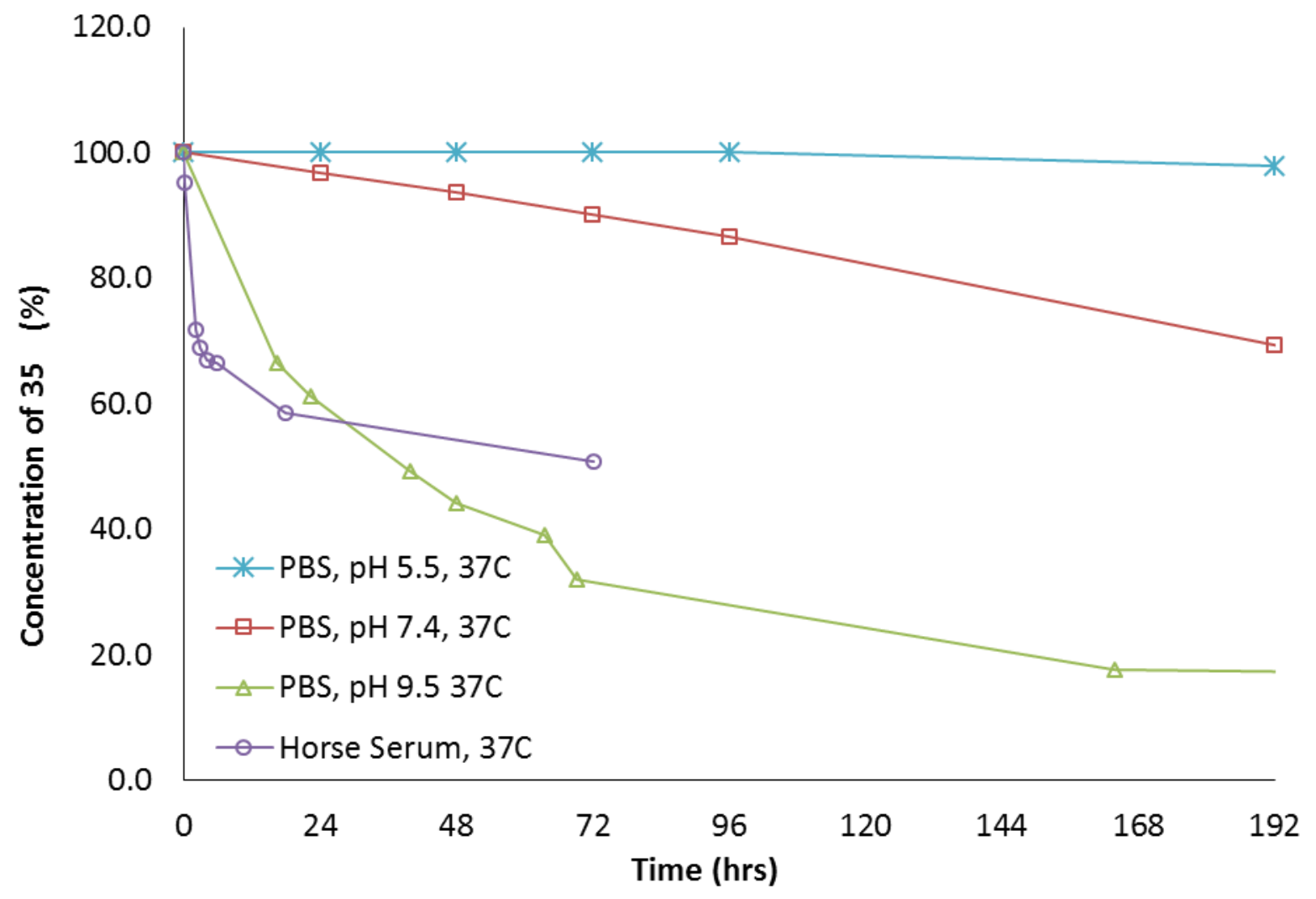

Figure 3.2 - Time dependent cleavage of $\mathbf{3 5}$ under various conditions. 


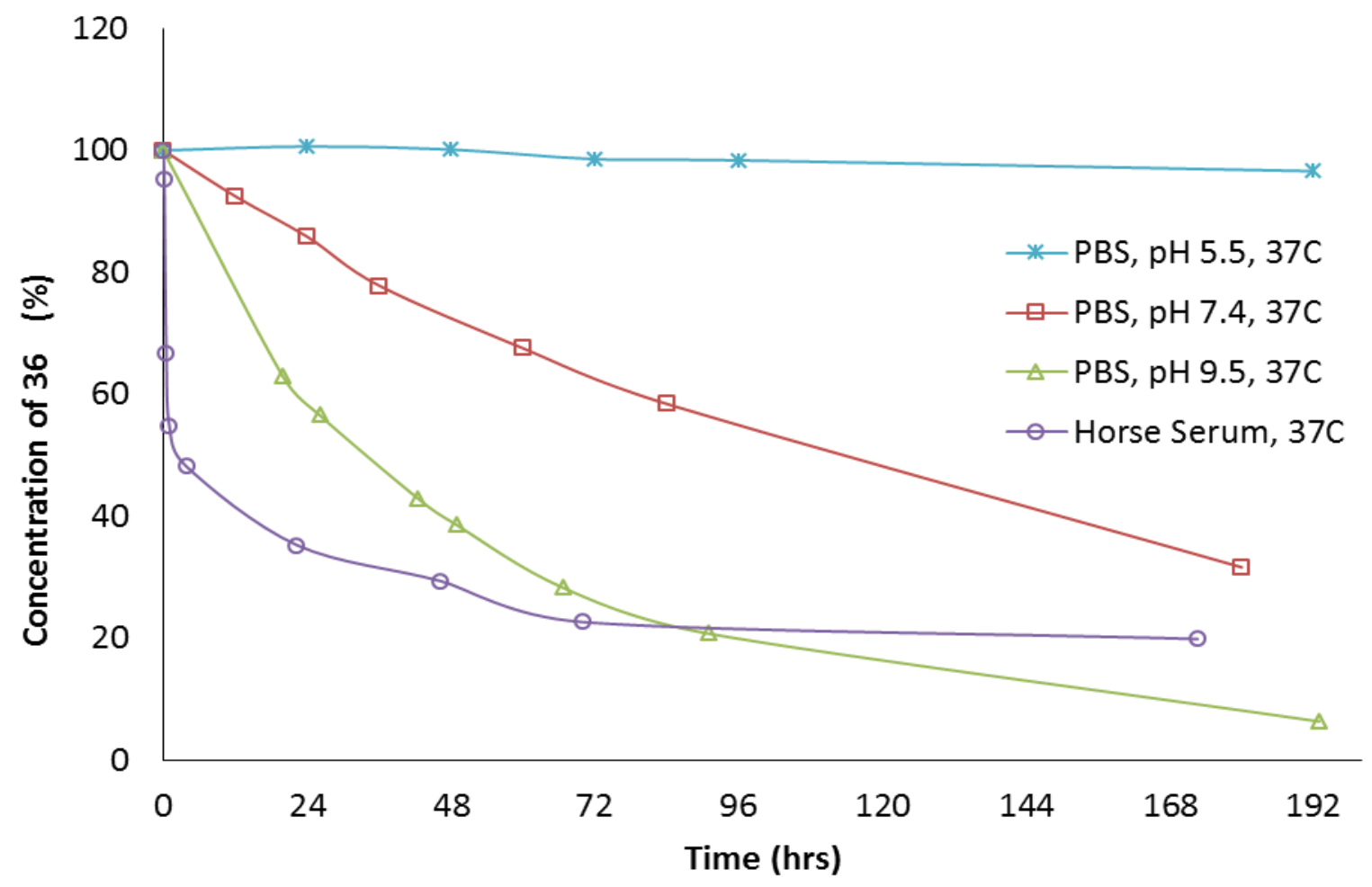

Figure 3.3 - Time dependent cleavage of $\mathbf{3 6}$ under various conditions.

The half-lives $\left(\mathrm{t}_{1 / 2}\right)$ were calculated based on the decline in the percent area of the prodrug peak obtained by the florescence detector. The slope of the decline was used to calculate the half-life of each prodrug in various media. The results are demonstrated in Table 3.1. The prodrug with the carbamate linkage (34) showed to be stable under all the conditions tested in this study. The half-lives for releasing the $\mathbf{1 1}$ (hm-MC4-PPEA) from $\mathbf{3 5}$ were 666, 18.9, and 1.7 days respectively at $\mathrm{pH} 5.5,7.4$, and 9.5. Half-life of the drug release from $\mathbf{3 5}$ in horse serum was 4.6 hours. The prodrug containing ester as the cleavable linker (36) showed to be the least stable with half-lives of 200, 5.4, and 1.5 days respectively at $\mathrm{pH} 5.5,7.4$, and 9.5. In horse serum, the half-life for releasing the drug from $\mathbf{3 6}$ was 1 hour. 
Table 3.1 - Half-life $\left(\mathrm{t}_{1 / 2}\right)$ Stability of the Cleavable Linkers in PBS and Horse Serum at $37{ }^{\circ} \mathrm{C}$

\begin{tabular}{cccccc}
\hline Compound & Structure & PBS & PBS & PBS & Horse Serum \\
& & pH 5.5 (day) & pH 7.4 (day) & pH 9.5 (day) & (hr) \\
\hline 34 & Stable & Stable & Stable & 4.6 \\
$\mathbf{3 6}$ & 666 & 18.9 & 1.7 & 1
\end{tabular}

\subsubsection{MTT assay and IC50 measurements}

The activity of 34-36, as well as the free drug (11) was evaluated using MTT assay, ${ }^{54}$ against cancerous human breast cell lines T47D (Figure 3.4) and MCF7(Figure 3.5), as well as noncancerous human breast epithelium 184A1 (Figure 3.6). The concentration dependent cell viability exhibited by $\mathbf{3 4 - 3 6}$ against these cell lines in vitro is demonstrated in Table 3.2.

Compound 34 exhibited $\mathrm{IC}_{50}$ of $>200 \mathrm{nM}, 32.0 \pm 0.4 \mathrm{nM}$, and 9.1 $\pm 0.9 \mathrm{nM}$ for MCF7, T47D, and 184A1 cell lines, respectively. Compound 16 exhibited $\mathrm{IC}_{50}$ of $81.0 \pm 2.5 \mathrm{nM}, 2.9 \pm 0.3 \mathrm{nM}$, and $4.7 \pm 1.0 \mathrm{nM}$ for MCF7, T47D, and 184A1 cell lines, respectively. Compound 17 exhibited $\mathrm{IC}_{50}$ of $34.0 \pm 1.3 \mathrm{nM}, 5.5 \pm 0.5 \mathrm{nM}$, and $1.8 \pm 0.5 \mathrm{nM}$ for MCF7, T47D, and 184A1 cell lines, respectively. The activity of these prodrugs show correlation with the stability studies in PBS buffer. The carbamate prodrug $(\mathbf{3 4})$ which showed to be stable under all the conditions that were tested, demonstrated the lowest activity out of all other prodrugs. Carbonate prodrug (35) with its 
relatively longer half-lives in both buffers and horse serum, showed higher activity than $\mathbf{3 4}$. The ester prodrug (36) showed the highest activity and nearly similar to that of the free drug $\mathbf{1 1}$ (hmMC4-PPEA) which exhibited $\mathrm{IC}_{50}$ of $34.0 \pm 1.5 \mathrm{nM}, 4.9 \pm 0.3 \mathrm{nM}$, and 1.9 $\pm 0.4 \mathrm{nM}$ for MCF7, T47D, and 184A1 cell lines, respectively. The cell lines were incubated in bovine serum which contains natural esterase enzymes similar to that of horse serum and human blood. There was also a three hour incubation time at $37^{\circ} \mathrm{C}$, which similar to our linker stability test allowed enough time for hydrolysis of the linkers and release of the free drug. So the prodrug activity observed has similar trend to that observed by the serum stability test.

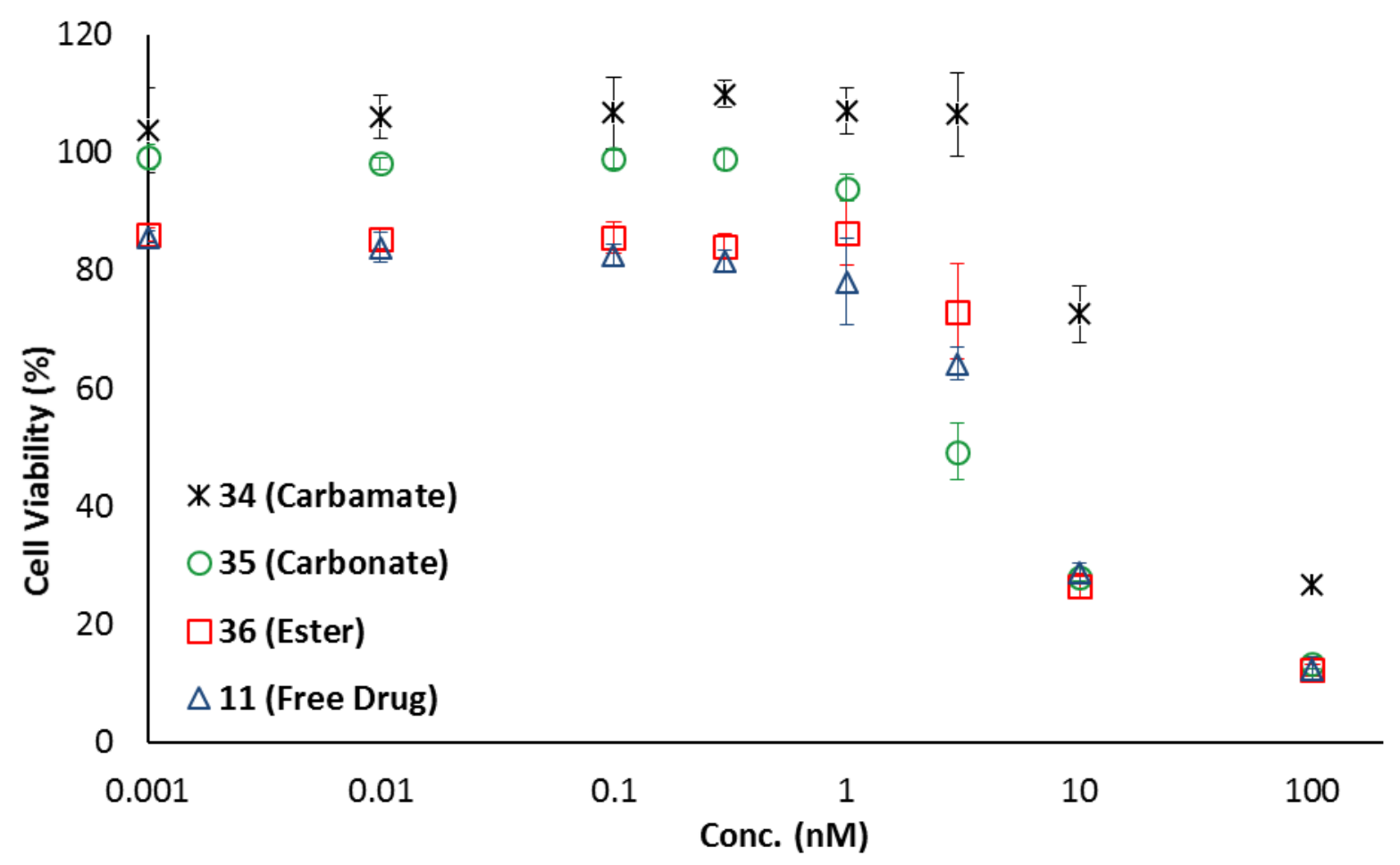

Figure 3.4 - Concentration dependent cell viability 11, 34, 35, and 36 against the T47D human breast cancer cell line. 


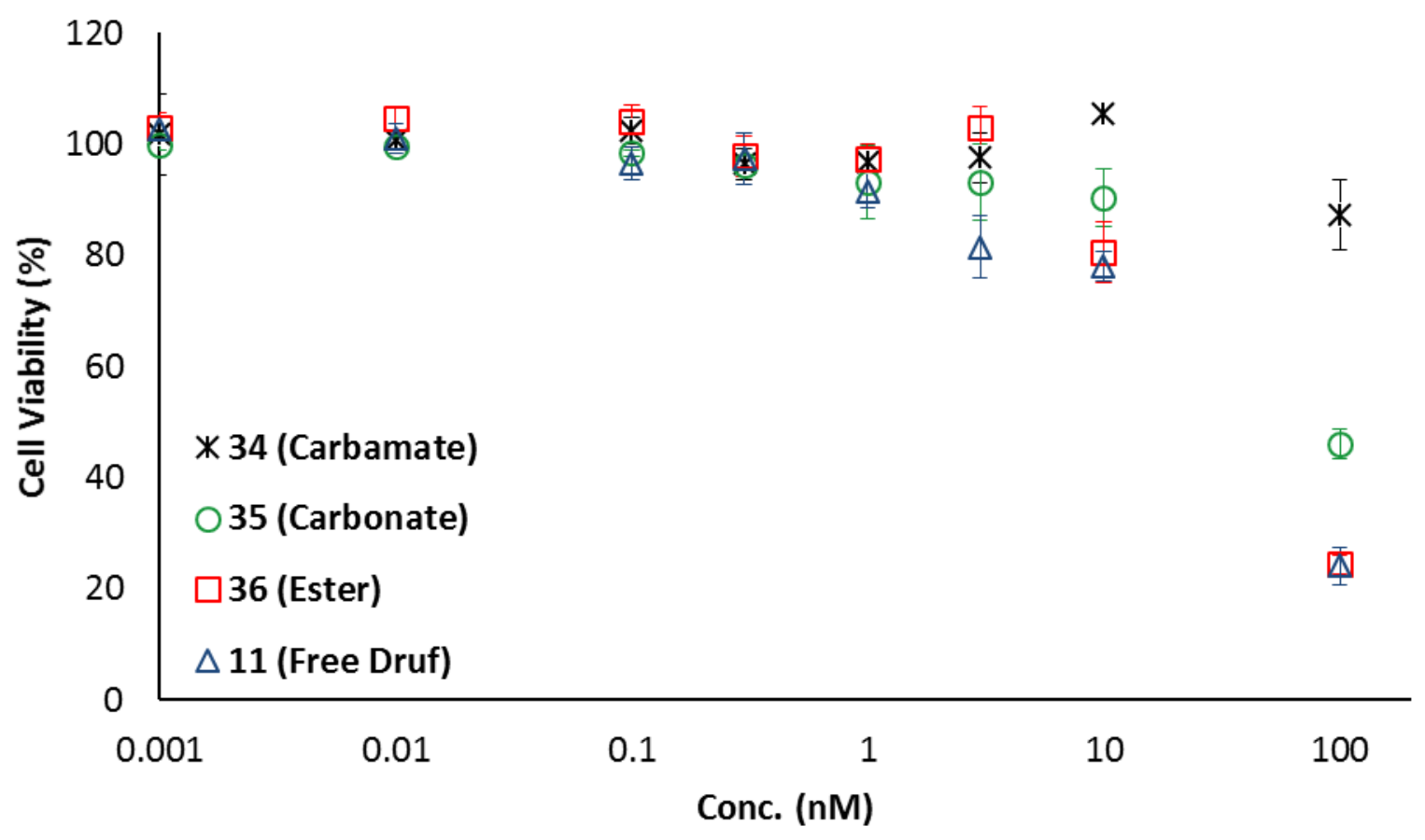

Figure 3.5 - Concentration dependent cell viability 11, 34, 35, and 36 against the MCF7 human breast cancer cell line. 


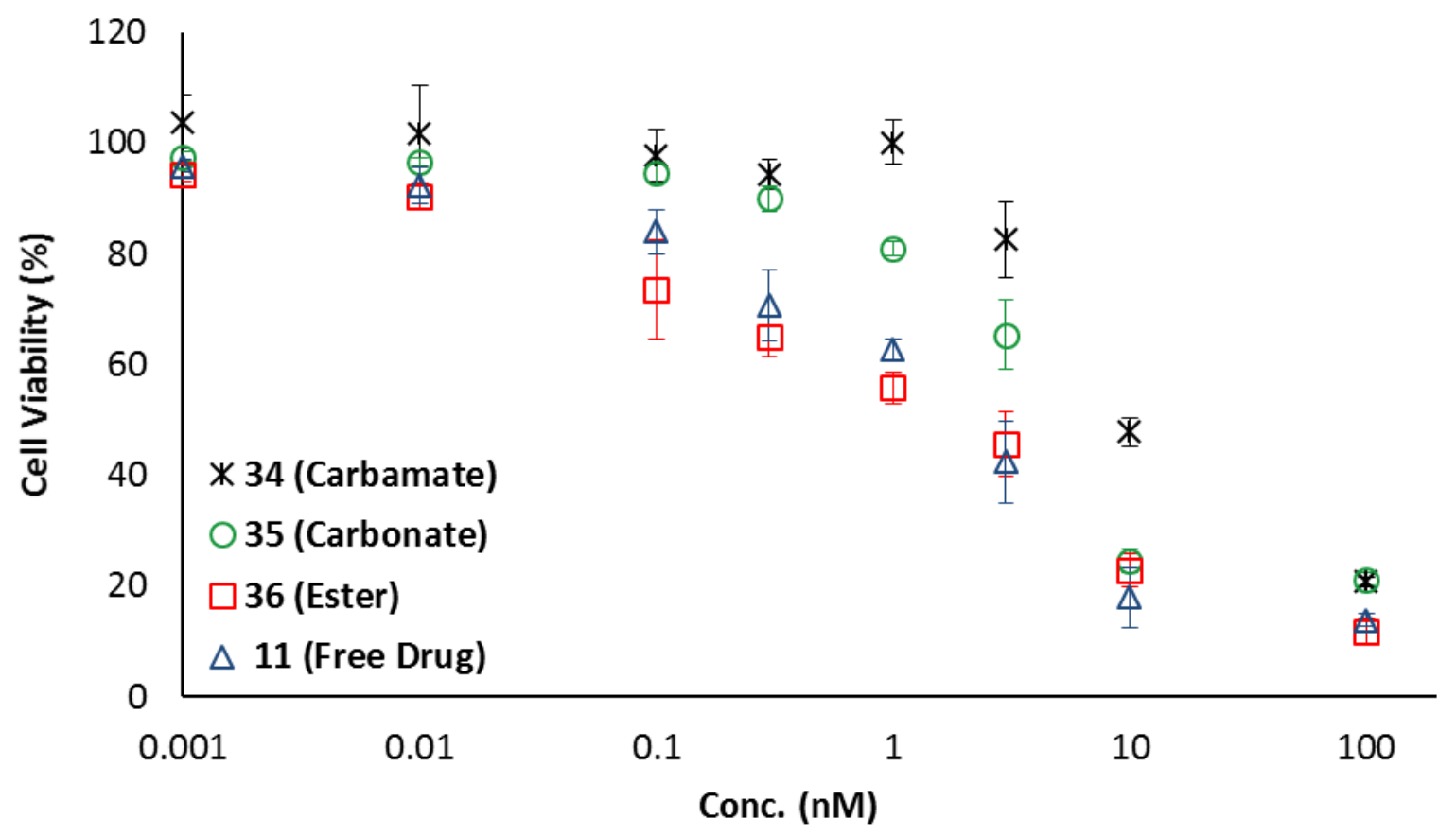

Figure 3.6 - Concentration dependent cell viability 11, 34, 35, and $\mathbf{3 6}$ against the 184A1 human breast cancer cell line.

Table 3.2 - $\mathrm{IC}_{50}$ of Free-Drug (11) and Prodrugs (34-36) in Various Human Breast Cell Lines

\begin{tabular}{ccccc}
\hline Cell Lines & $\mathbf{1 1}(\mathrm{nM})$ & $\mathbf{3 4}(\mathrm{nM})$ & $\mathbf{3 5}(\mathrm{nM})$ & $\mathbf{3 6}(\mathrm{nM})$ \\
\hline 184A1 & $1.9 \pm 0.4$ & $9.1 \pm 0.9$ & $4.7 \pm 1.0$ & $1.8 \pm 0.5$ \\
T47D & $4.9 \pm 0.3$ & $32.0 \pm 0.4$ & $2.9 \pm 0.3$ & $5.5 \pm 0.5$ \\
MCF7 & $34.0 \pm 1.5$ & $>200$ & $81.0 \pm 2.5$ & $34.0 \pm 1.3$
\end{tabular}




\subsection{Conclusion}

Several linker models capable of reacting with drug molecules containing primary alcohols have been proposed. These linkers utilize click type chemistry for simple, and high yielding attachment to a fluorophore. The synthesis, biological activities, and serum stabilities of a new class of prodrug derivatives of MC4-PPEA were described. These molecules are covalently linked through different hydrolytically or enzymatically cleavable moieties, each bearing an azide at its distal end. The prodrug with the carbamate linkage (34) showed to be the most stable under all the conditions tested in this study, followed by the carbonate prodrug (35). The ester prodrug (36) was the least stable under similar conditions with half-lives of 200, 5.4, and 1.5 days respectively in PBS buffer at $\mathrm{pH}$ 5.5, 7.4, and 9.5. In horse serum, the half-life for releasing the drug from $\mathbf{3 6}$ was 1 hour. The drug activity of the prodrugs directly correlated with their buffer and serum stability. $\mathbf{3 6}$ demonstrated $\mathrm{IC}_{50}$ similar to that of the free-drug.

\subsection{Experimental}

\subsubsection{Material}

All manipulations were performed under nitrogen atmosphere unless stated otherwise. All anhydrous solvents; $n$-butyllithium (2.5 M solution in hexane), $n$-BuLi; paraformaldehyde, PFA; 1-chloro-4-iodobutane, $\mathrm{Cl}\left(\mathrm{CH}_{2}\right)_{4} \mathrm{I} ; \mathrm{HCl}$ (37\%); sodium azide, $\mathrm{NaN}_{3}$; sodium iodide, $\mathrm{NaI}$; potassium iodide, $\mathrm{KI}$; triphenylphosphine, $\mathrm{PPh}_{3}$; sodium sulfate, $\mathrm{Na}_{2} \mathrm{SO}_{4}$; magnesium sulfate, $\mathrm{MgSO}_{4}$; Sodium thiosulfate, $\mathrm{Na}_{2} \mathrm{~S}_{2} \mathrm{O}_{3}$; trans-3-(3'-pyridyl)acrylic acid, $\mathrm{C}_{5} \mathrm{NH}_{4}(\mathrm{CH})_{2} \mathrm{COOH}$; thionyl chloride, $\mathrm{SOCl}_{2}$; Hünig's Base, DIPEA; pyridine, $\mathrm{C}_{5} \mathrm{H}_{5} \mathrm{~N}$; chloromethyl chloroformate, $\mathrm{ClCH}_{2} \mathrm{CO}_{2} \mathrm{Cl}$; diethylene glycol; tosyl chloride, TsCl; silver oxide, $\mathrm{Ag}_{2} \mathrm{O}$; propargyl bromide, 
$\mathrm{CHCCH}_{2} \mathrm{Br}$; chromium trioxide, $\mathrm{CrO}_{3}$; and dansyl chloride were purchased from Aldrich and used as received. All solvents were dried using $3 \AA$ molecular sieves $(20 \% \mathrm{~m} / \mathrm{v}) .{ }^{57}$ Silica gel was

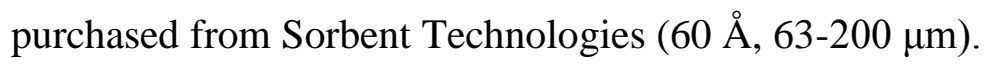

\subsubsection{Instrumentation}

NMR spectra were recorded on Bruker DRX300, DRX500, Bruker Ultrashield400 and Ultrashield500 Plus Nuclear Magnetic Spectrometers and analyzed using TopSpin. Chemical shifts $\left(\delta\right.$, ppm) for ${ }^{1} \mathrm{H}$ and ${ }^{13} \mathrm{C}$ were referenced to residual solvent peaks. Mass spectra were obtained on an ABI QSTAR under both positive and negative modes and reported in $\mathrm{m} / \mathrm{z}$. and analyzed using Mariner Biospectrometry Workstation by PerSeptive Biosystems. For the stability tests, Agilent 1100 series HPLC system equipped with an auto sampler and coupled to an UV-Vis, and a Fld detector was used. HPCORE Chem Station was used for data analysis. Triply distilled water was used as the eluent with 5-95\% gradient of HPLC grade acetonitrile.

\subsubsection{Cell cultures and treatment}

All cell lines were obtained from ATCC (Manassas, VA). MCF-7 and T47D cells were maintained in DMEM media containing $350 \mu \mathrm{L} \cdot \mathrm{L}^{-1}$ gentamicin and $25 \mathrm{~mL} \cdot \mathrm{L}^{-1}$ fetal bovine serum. 184A1 cells were maintained in HuMEC media containing $175 \mu \mathrm{L} \cdot \mathrm{L}^{-1}$ gentamicin, HuMEC supplement, and bovine pituitary extract. The cells were grown to confluency in either $\mathrm{T}-12.5 \mathrm{~cm}^{2}$ or $\mathrm{T}-25 \mathrm{~cm}^{2}$ tissue culture flasks using an incubator maintained at $5 \% \mathrm{CO}_{2}$ humid atmosphere at $37^{\circ} \mathrm{C}$. The MTT assay ${ }^{54}$ was carried out as follows: MCF-7, T47D, and 184A1 cells were plated in 96 well plates at a density of 10,000 cells per well for overnight at $37{ }^{\circ} \mathrm{C}$. The cells were then treated with different doses of the test agent for $72 \mathrm{~h}$. MTT reagent was 
added to the cells for $4 \mathrm{~h}$ for developing formazan crystals. Solubilization buffer was added to the wells and the absorbance was measured at $570 \mathrm{~nm}$. The experiments were repeated four times and the standard deviations are reported.

\subsubsection{The procedure for the synthesis of clickable fluorophore}

2-(2-azidoethoxy)ethan-1-ol (20). In a $25 \mathrm{~mL}$ 3-neck round bottom flask, 2-(2chloroethoxy)ethan-1-ol (5.00 g, $4.24 \mathrm{ml}, 40.1 \mathrm{mmol}$ ) was dissolved in $\mathrm{H}_{2} \mathrm{O}(50 \mathrm{~mL}) . \mathrm{NaN}_{3}$ (5.22 g, $80.3 \mathrm{mmol}$ ) was added and the mixture was refluxed at $70{ }^{\circ} \mathrm{C}$ overnight. Solvents were removed under vacuum and the crude was redissolved in $\mathrm{H}_{2} \mathrm{O}(8 \mathrm{~mL})$ and extracted with EtOAc $(5 \times 8 \mathrm{~mL})$. Combined organics were washed with brine $(10 \mathrm{~mL})$ and the brine solution was reextracted using EtOAc $(4 \times 10 \mathrm{~mL})$. Organic phase was then dried on $\mathrm{MgSO}_{4}$, and concentrated to afford $4.56 \mathrm{~g}$ of pure product (20) as clear oil (Yield: $89 \%) .{ }^{1} \mathrm{H} \mathrm{NMR}\left(500 \mathrm{MHz}, \mathrm{CDCl}_{3}\right): \delta=$ $3.71(\mathrm{t}, J 4.7,2 \mathrm{H}), 3.66(\mathrm{t}, J 5.0,2 \mathrm{H}), 3.57(\mathrm{t}, J 4.5,2 \mathrm{H}), 3.38(\mathrm{t}, J 4.8,2 \mathrm{H}), 2.49-2.46(\mathrm{~m}, \mathrm{br}$, 1H). $\left.{ }^{13} \mathrm{C} \mathrm{NMR} \mathrm{(126} \mathrm{MHz,} \mathrm{CDCl}_{3}\right): \delta=72.69,70.24,61.95,50.94$. HRMS (ESI, pos.) for $\mathrm{C}_{4} \mathrm{H}_{9} \mathrm{~N}_{3} \mathrm{O}_{2}$ : calcd 154.0587 (M+Na), found 154.0674.

Reagent (20) was also synthesized using $24 a$ ( $824 \mathrm{mg}, 3.17 \mathrm{mmol}$ ) and $\mathrm{NaN}_{3}(412 \mathrm{mg}, 6.33$ mmol) in 1:1 solution of $\mathrm{EtOH} / \mathrm{H}_{2} \mathrm{O}(8 \mathrm{~mL})$, using the same conditions described above to afford $347 \mathrm{mg}$ of pure product (20) as clear oil (Yield: $84 \%$ ).

3-(2-(2-azidoethoxy)ethoxy)prop-1-yne (21). In a $100 \mathrm{~mL}$ 2-neck round bottom flask, THF (20 mL) was added to $60 \%$ dispersion of $\mathrm{NaH}$ in mineral oil ( $0.85 \mathrm{~g}, 21 \mathrm{mmol})$. The suspension was cooled to $0{ }^{\circ} \mathrm{C}$, while stirring, and (20) $(1.39 \mathrm{~g}, 1.25 \mathrm{~mL}, 10.6 \mathrm{mmol})$ was added gradually. The reaction was allowed to reach ambient temperature and once hydrogen gas 
stopped bubbling out of the reaction mixture, the solution was cooled to $0{ }^{\circ} \mathrm{C}$ again and $80 \mathrm{wt} . \%$ propargyl bromide in toluene $(1.89 \mathrm{~g}, 1.42 \mathrm{~mL}, 12.7 \mathrm{mmol})$ was added drop wise. The resulting solution was allowed to stir for 3 hours while slowly reaching ambient temperature. Reaction mixture was then cooled to $0{ }^{\circ} \mathrm{C}$ and quenched with $\mathrm{H}_{2} \mathrm{O}(3 \mathrm{~mL}) .1 \mathrm{M} \mathrm{NH}_{4} \mathrm{Cl}_{(\mathrm{aq})}(20 \mathrm{~mL})$ and $\mathrm{Et}_{2} \mathrm{O}(3 \mathrm{~mL})$ was added and the organic layer was extracted. $\mathrm{Et}_{2} \mathrm{O}(2 \times 23 \mathrm{~mL})$ was used to extract again and combined organics were dried on $\mathrm{MgSO}_{4}$, filtered, and concentrated under reduced pressure and purified by silica gel column chromatography using a EtOAc:Hex gradient, to afford $1.15 \mathrm{~g}$ of (21) as orange oil (Yield: $64 \%) .{ }^{1} \mathrm{H}$ NMR $\left(500 \mathrm{MHz}, \mathrm{CDCl}_{3}\right): \delta=4.21(\mathrm{~d}, J$ 2.5, 2H), 3.73-3.66 (m, 6H), $3.40(\mathrm{t}, J 5.0,2 \mathrm{H}), 2.43(\mathrm{t}, J 2.2,1 \mathrm{H}) .{ }^{13} \mathrm{C} \mathrm{NMR}\left(126 \mathrm{MHz}, \mathrm{CDCl}_{3}\right)$ : $\delta=79.87,74.92,70.83,70.39,69.50,58.82,51.00$

2-(2-(prop-2-yn-1-yloxy)ethoxy)ethan-1-amine (22). In a $50 \mathrm{~mL}$ 2-neck round bottom flask equipped with a purge needle attached to a bubbler, (21) (1.12 g, $6.60 \mathrm{mmol})$ was dissolved in THF (11 mL). $\mathrm{PPh}_{3}(2.60 \mathrm{~g}, 9.90 \mathrm{mmol})$ and DI water $(0.20 \mathrm{~mL})$ was added all at once and the solution was stirred overnight. All solvents were removed under reduced pressure and crude was redissolved in $2 \mathrm{M} \mathrm{HCl}_{(\mathrm{aq})}(11 \mathrm{~mL})$ and $\mathrm{Et}_{2} \mathrm{O}(11 \mathrm{~mL})$ while stirring vigorously. The ppt was filtered using a medium grade frit funnel and the filtrate was transferred to a separating funnel. The organic layer was extracted and $\mathrm{Et}_{2} \mathrm{O}(2 \times 20 \mathrm{~mL})$ was used to extract again. $10 \mathrm{M} \mathrm{NaOH}_{(\mathrm{aq})}$ was added to the aqueous layer to adjust the $\mathrm{pH}$ to 12 and $\mathrm{DCM}(3 \times 20 \mathrm{~mL})$ was used to extract the product. Combined organics were dried on $\mathrm{MgSO}_{4}$, filtered, and concentrated under reduced pressure to afford $0.76 \mathrm{~g}$ of (22) as dark orange oil (Yield: $80 \%) .{ }^{1} \mathrm{H} \mathrm{NMR}\left(500 \mathrm{MHz}, \mathrm{CDCl}_{3}\right): \delta$ $=4.20(\mathrm{~d}, J 2.0,2 \mathrm{H}), 3.70-3.67(\mathrm{~m}, 2 \mathrm{H}), 3.65-3.61(\mathrm{~m}, 2 \mathrm{H}), 3.51(\mathrm{t}, J 5.3,2 \mathrm{H}), 2.87(\mathrm{t}, J 4.8$, $2 \mathrm{H}), 2.43(\mathrm{t}, J 2.5,1 \mathrm{H}), 1.79(\mathrm{~s}, 2 \mathrm{H}) .{ }^{13} \mathrm{C} \mathrm{NMR}\left(126 \mathrm{MHz}, \mathrm{CDCl}_{3}\right): \delta=79.90,74.91,73.57$, 
70.42, 69.41, 58.74, 42.00. HRMS (ESI, pos.) for $\mathrm{C}_{7} \mathrm{H}_{13} \mathrm{NO}_{2}$ : calcd $144.1019(\mathrm{M}+\mathrm{H})$, found 144.0943.

\section{5-(dimethylamino)-N-(2-(2-(prop-2-yn-1-yloxy)ethoxy)ethyl)naphthalene-1-}

sulfonamide (23). In a $10 \mathrm{~mL}$ round bottom flask under nitrogen, dansyl chloride (100 mg, $0.370 \mathrm{mmol})$ was dissolved in THF ( $1 \mathrm{~mL})$ and cooled to $0{ }^{\circ} \mathrm{C}$ in an ice bath. Hünig's base (71 $\mu \mathrm{L}, 0.41 \mathrm{mmol})$, and (22) $(58 \mathrm{mg}, 0.41 \mathrm{mmol})$ were dissolved in THF $(1 \mathrm{~mL})$ and added and the reaction mixture drop wise. Ice bath was removed and the reaction vessel was cover with foil and allowed to stir overnight. Following day, $\mathrm{Et}_{2} \mathrm{O}$ was added to the reaction mixture to promote precipitation and the mixture was filtered using a fine grade frit funnel. The filtrate was concentrated under vacuum, and the crude was purified using silica gel column chromatography using a gradient of EtOAc:Hex (5-100\%) to afford $134 \mathrm{mg}$ of (23) as yellow/green thick oil that hardened overtime in the fridge (Yield: $96 \%) .{ }^{1} \mathrm{H}$ NMR $\left(300 \mathrm{MHz}, \mathrm{CD}_{2} \mathrm{Cl}_{2}\right): \delta=8.60(\mathrm{~d}, \mathrm{~J} 8.7$, $1 \mathrm{H}), 8.31-8.25(\mathrm{~m}, 2 \mathrm{H}), 7.67-7.56(\mathrm{~m}, 2 \mathrm{H}), 7.26(\mathrm{~d}, J 7.2,1 \mathrm{H}), 5.32(\mathrm{t}, J 5.5,1 \mathrm{H}), 4.14(\mathrm{~d}, J 2.4$, $2 \mathrm{H}), 3.53-3.5(\mathrm{~m}, 2 \mathrm{H}), 3.39-3.35(\mathrm{~m}, 4 \mathrm{H}), 3.10(\mathrm{q}, J 5.3,2 \mathrm{H}), 2.93(\mathrm{~s}, 6 \mathrm{H}), 2.53(\mathrm{t}, J 2.4,1 \mathrm{H})$. ${ }^{13} \mathrm{C}$ NMR $\left(75.5 \mathrm{MHz}, \mathrm{CD}_{2} \mathrm{Cl}_{2}\right): \delta=152.57,135.41,130.80,130.31,129.96,129.78,128.73$, 123.60, 118.95, 115.57, 80.03, 74.69, 70.41, 69.35, 69.31, 58.60, 45.59, 43.52. HRMS (ESI, pos.) for $\mathrm{C}_{19} \mathrm{H}_{24} \mathrm{~N}_{2} \mathrm{O}_{4} \mathrm{~S}$ : calcd $377.1530(\mathrm{M}+\mathrm{H})$, found 377.1586 .

\subsubsection{The procedure for the synthesis of prodrugs}

\section{2-(2-hydroxyethoxy)ethyl 4-methylbenzenesulfonate (24a) \& oxybis(ethane-2,1-diyl)}

bis(4-methylbenzenesulfonate) (24b). In a $100 \mathrm{~mL}$ 2-neck round bottom flask, diethylene glycol $(0.50 \mathrm{ml}, 4.2 \mathrm{mmol})$ was dissolved in DCM $(42 \mathrm{~mL})$ and cooled to $0{ }^{\circ} \mathrm{C}$ in an ice bath. $\mathrm{Ag}_{2} \mathrm{O}(1.47 \mathrm{~g}, 6.32 \mathrm{mmol}), \mathrm{TsCl}(0.88 \mathrm{~g}, 4.6 \mathrm{mmol})$, and catalytic amount of $\mathrm{KI}(0.14 \mathrm{~g}, 0.84$ 
mmol) was added and the mixture was stirred for 6 hours. The reaction mixture was filtered through a pad of silica and washed with EtOAc. Solvents were removed under vacuum and the crude was purified using silica gel column chromatography using a gradient of EtOAc:hexane (30-60\%) to afford $848 \mathrm{mg}$ of mono-substituted product (24a) as a clear oil (Yield: $77 \%$ ), and 80 mg of di-substituted product (24b) as a solid (Yield: 8\%). 24a: ${ }^{1} \mathrm{H}$ NMR $\left(500 \mathrm{MHz}, \mathrm{CDCl}_{3}\right): \delta=$ $7.79(\mathrm{~d}, J 8.0,2 \mathrm{H}), 7.34(\mathrm{~d}, J 8.0,2 \mathrm{H}), 4.18(\mathrm{t}, J 4.8,2 \mathrm{H}), 3.68(\mathrm{t}, J 4.8,2 \mathrm{H}), 3.66(\mathrm{t}, J 4.5,2 \mathrm{H})$, $3.52(\mathrm{t}, J 4.5,2 \mathrm{H}), 2.44(\mathrm{~s}, 3 \mathrm{H}), 2.12(\mathrm{~s}, \mathrm{br}, 1 \mathrm{H}) .{ }^{13} \mathrm{C} \mathrm{NMR}\left(126 \mathrm{MHz}, \mathrm{CDCl}_{3}\right): \delta=145.27$, 133.28, 130.16, 128.25, 72.79, 69.49, 68.88, 61.93, 21.94. HRMS (ESI, pos.) for $\mathrm{C}_{11} \mathrm{H}_{16} \mathrm{O}_{5} \mathrm{~S}$ : calcd 261.0791 $(\mathrm{M}+\mathrm{H})$, found 261.0992. 24b: ${ }^{1} \mathrm{H}$ NMR $\left(300 \mathrm{MHz}, \mathrm{CDCl}_{3}\right): \delta=7.78(\mathrm{~d}, \mathrm{~J} 8.1$, 4H), $7.35(\mathrm{~d}, \mathrm{~J} 8.4,4 \mathrm{H}), 4.09(\mathrm{t}, J 4.6,4 \mathrm{H}), 3.60(\mathrm{t}, J 4.7,4 \mathrm{H}), 2.45(\mathrm{~s}, 6 \mathrm{H}) .{ }^{13} \mathrm{C}$ NMR $(75.5$ $\mathrm{MHz}_{\mathrm{CDCl}}$ ): $\delta=145.30,133.20,130.24,128.29,69.33,39.09,21.99$. HRMS (ESI, pos.) for $\mathrm{C}_{18} \mathrm{H}_{22} \mathrm{O}_{7} \mathrm{~S}_{2}$ : calcd $437.0699(\mathrm{M}+\mathrm{Na})$, found 437.1125 .

1-azido-2-(2-azidoethoxy)ethane (25). In a 100 mL 2-neck round bottom flask, 24b (2.00 g, $4.83 \mathrm{mmol})$ and $\mathrm{NaN}_{3}(689 \mathrm{mg}, 10.6 \mathrm{mmol})$ were dissolved in DMF (26 mL) and the mixture was refluxed at $50{ }^{\circ} \mathrm{C}$ overnight. Reaction mixture was cooled to ambient temperature and $5 \% \mathrm{LiCl}_{(\mathrm{aq})}(30 \mathrm{~mL})$ was added and product was extracted with EtOAc $(2 \times 30 \mathrm{~mL})$. Combined organics were washed with $5 \% \mathrm{LiCl}_{(\mathrm{aq})}(30 \mathrm{~mL})$, then brine $(30 \mathrm{~mL})$. Organic phase was then dried on $\mathrm{MgSO}_{4}$, and concentrated to afford $680 \mathrm{mg}$ of pure product (25) as pale yellow oil (Yield: 90\%). ${ }^{1} \mathrm{H}$ NMR (300 MHz, $\left.\mathrm{CDCl}_{3}\right): \delta=3.66(\mathrm{t}, J 5.1,4 \mathrm{H}), 3.39(\mathrm{t}, J 4.9,4 \mathrm{H}) .{ }^{13} \mathrm{C}$ $\operatorname{NMR}\left(75.5 \mathrm{MHz}, \mathrm{CDCl}_{3}\right): \delta=70.35,51.03$. HRMS (ESI, pos.) for $\mathrm{C}_{4} \mathrm{H}_{8} \mathrm{~N}_{6} \mathrm{O}$ : calcd 155.0687 (M-H), found 155.1585. 
2-(2-azidoethoxy)ethan-1-amine (26). In a $50 \mathrm{~mL}$ 2-neck round bottom flask equipped with a purge needle attached to a bubbler, (25) $(680 \mathrm{mg}, 4.35 \mathrm{mmol})$ was dissolved in 1:1 mixture of $\mathrm{Et}_{2} \mathrm{O}: \mathrm{EtOAc}(10 \mathrm{~mL})$ and $5 \% \mathrm{HCl}_{(\mathrm{aq})}(10 \mathrm{~mL})$, cooled to $0{ }^{\circ} \mathrm{C}$, and stirred at $300 \mathrm{rpm}$. $\mathrm{PPh}_{3}(1.14 \mathrm{~g}, 4.35 \mathrm{mmol})$ was dissolved in 1:1 mixture of $\mathrm{Et}_{2} \mathrm{O}: \mathrm{EtOAc}(12 \mathrm{~mL})$ and added at a rate of $0.2 \mathrm{~mL} / \mathrm{min}$. The solution was allowed to reach ambient temperature while stirring overnight. $2 \mathrm{M} \mathrm{HCl}_{(\mathrm{aq})}(10 \mathrm{~mL})$ was added and the mixture was transferred to a separating funnel. Organic layer was extracted and the aqueous phase was re-extracted using DCM $(3 \times 20 \mathrm{~mL})$. Using $10 \mathrm{M} \mathrm{NaOH}, \mathrm{pH}$ of the aqueous phase was adjusted to 12 and the product was extracted with DCM $(3 \times 20 \mathrm{~mL})$. Combined extracts were combined, dried on $\mathrm{MgSO}_{4}$, and concentrated to afford $373 \mathrm{mg}$ of pure product (26) as faint yellow oil (Yield: 66\%). ${ }^{1} \mathrm{H}$ NMR (500 MHz, $\left.\mathrm{CDCl}_{3}\right): \delta=3.64(\mathrm{t}, J 5.0,2 \mathrm{H}), 3.50(\mathrm{t}, J 5.2,2 \mathrm{H}), 3.36(\mathrm{t}, J 5.0,2 \mathrm{H}), 2.87(\mathrm{t}, J 4.7,2 \mathrm{H}), 1.58(\mathrm{~s}$, br, $2 \mathrm{H}) .{ }^{13} \mathrm{C}$ NMR $\left(126 \mathrm{MHz}, \mathrm{CDCl}_{3}\right): \delta=73.66,70.26,51.03,42.06$. HRMS (ESI, pos.) for $\mathrm{C}_{4} \mathrm{H}_{10} \mathrm{~N}_{4} \mathrm{O}$ : calcd $131.0927(\mathrm{M}+\mathrm{H})$, found 131.0971.

\section{1-(methyl(4-nitrophenyl carbonate))-7-(4'-(trans-3"'-(3"'-pyridyl)acrylamido)butyl)-}

1,7-dicarbadodecaborane (27). In a $10 \mathrm{~mL}$ round bottom flask under nitrogen, 11 (12 mg, 30 $\mu \mathrm{mol})$ was dissolved in THF $(1 \mathrm{~mL})$ and pyridine $(3.9 \mu \mathrm{L}, 50 \mu \mathrm{mol})$ was added. Solution was cooled to $0{ }^{\circ} \mathrm{C}$ in an ice bath while stirring. 4-nitrophenyl chloroformate $(10 \mathrm{mg}, 50 \mu \mathrm{mol})$ was dissolved in THF $(0.5 \mathrm{~mL})$ and added to the reaction mixture drop wise. The reaction was allowed to stir overnight while reach ambient temperature. Reaction was quenched using $1 \mathrm{M}$ $\mathrm{NH}_{4} \mathrm{Cl}_{(\mathrm{aq})}(5 \mathrm{~mL})$ and $\mathrm{Et}_{2} \mathrm{O}(5 \mathrm{~mL})$ was added. It was then transferred to a separatory funnel and the organic layer was separated. $\mathrm{Et}_{2} \mathrm{O}(5 \mathrm{~mL})$ was used to extract again and combined organics were wash with saturated $\mathrm{NaHCO}_{3}(3 \times 10 \mathrm{~mL})$, brine $(10 \mathrm{~mL})$, dried on $\mathrm{MgSO}_{4}$, filtered, and concentrated, and purified using silica gel column chromatography using a gradient of 
MeOH: $\mathrm{CHCl}_{3}(2-10 \%)$ to afford $15 \mathrm{mg}$ of (27) as peach colored solid (Yield: 88\%). ${ }^{1} \mathrm{H}$ NMR (500 MHz, $\left.\mathrm{CDCl}_{3}\right): \delta=8.76(\mathrm{~s}, 1 \mathrm{H}), 8.57(\mathrm{~d}, J 3.5,1 \mathrm{H}), 8.31-8.27(\mathrm{~m}, 2 \mathrm{H}), 7.79(\mathrm{~d}, J 8.0,1 \mathrm{H})$, $7.61(\mathrm{~d}, J 16.0,1 \mathrm{H}), 7.40-7.27(\mathrm{~m}, 2 \mathrm{H}), 7.33\left(\mathrm{dd},{ }^{3} J 7.8,{ }^{4} J 5.0,1 \mathrm{H}\right), 6.47(\mathrm{~d}, J 15.5,1 \mathrm{H}), 5.83(\mathrm{~s}$, br, 1H), 4.44 (s, 2H), 3.36 (q, J 6.7, 2H), 2.00 (t, J 8.5, 2H), 1.52 (p, J 7.2, 2H), 1.46-1.40 (m, 2H), 3.30-1.60 (m, 10H, B-H). $\left.{ }^{13} \mathrm{C} \mathrm{NMR} \mathrm{(125.8} \mathrm{MHz,} \mathrm{CDCl}_{3}\right): \delta=165.44,155.47,151.93$, $150.43,149.16,146.02,137.80,135.07,131.11,125.76,124.16,123.12,122.07,76.56,71.47$, 69.08, 39.64, 36.83, 29.54, 27.63. HRMS (ESI, pos.) for $\mathrm{C}_{22} \mathrm{H}_{31} \mathrm{~B}_{10} \mathrm{~N}_{3} \mathrm{O}_{6}$ : calcd $542.3300(\mathrm{M}+\mathrm{H})$, found 542.3369 .

\section{1-(methyl(2-(2-azidoethoxy)ethyl)carbamate))-7-(4'-(trans-3"-(3'"'-}

pyridyl)acrylamido)butyl)-1,7-dicarbadodecaborane (28). In a $50 \mathrm{~mL}$ pear-shaped flask under nitrogen, (27) (109 mg, $200 \mu \mathrm{mol})$ was dissolved in DCM (2.0 mL) and Hünig's base (105 $\mu \mathrm{L}$, $600 \mu \mathrm{mol})$, and (26) (32 mg, $0.24 \mathrm{mmol}$ ) was added and the reaction was allowed to stir overnight. Solvent was removed under vacuum, and the crude was purified using silica gel column chromatography using a gradient of $\mathrm{MeOH}: \mathrm{CHCl}_{3}(1-10 \%)$ to afford $109 \mathrm{mg}$ of (28) as yellow oil (Yield: 98\%). ${ }^{1} \mathrm{H}$ NMR (500 MHz, $\left.\mathrm{CDCl}_{3}\right): \delta=8.75(\mathrm{~s}, 1 \mathrm{H}), 8.57(\mathrm{~d}, J 4.5,1 \mathrm{H}), 7.84$ $(\mathrm{d}, J 8.0,1 \mathrm{H}), 7.62(\mathrm{~d}, J 16.0,1 \mathrm{H}), 7.38\left(\mathrm{dd},{ }^{3} J 8.0,{ }^{4} J 5.0,1 \mathrm{H}\right), 6.52(\mathrm{~d}, J 15.5,1 \mathrm{H}), 6.06(\mathrm{~s}, \mathrm{br}$, 1H), 5.29 (s, br, 1H), $4.25(\mathrm{~s}, 2 \mathrm{H}), 3.66(\mathrm{t}, J$ 4.8, 2H), $3.56(\mathrm{t}, J 5.0,2 \mathrm{H}), 3.40-3.34(\mathrm{~m}, 6 \mathrm{H}), 1.94$ (t, $J$ 8.2, 2H), $1.50(\mathrm{p}, J 7.2,2 \mathrm{H}), 1.43-1.37(\mathrm{~m}, 2 \mathrm{H}), 3.10-1.60(\mathrm{~m}, 10 \mathrm{H}, \mathrm{B}-\mathrm{H}) .{ }^{13} \mathrm{C}$ NMR $(125.8$ $\left.\mathrm{MHz}, \mathrm{CDCl}_{3}\right): \delta=165.69,155.42,150.03,148.73,137.70,135.52,131.38,124.47,123.33$, 76.06, 73.45, 70.42, 70.16, 65.29, 50.97, 41.29, 39.84, 36.80, 29.41, 27.58. HRMS (ESI, neg.) for $\mathrm{C}_{20} \mathrm{H}_{36} \mathrm{~B}_{10} \mathrm{~N}_{6} \mathrm{O}_{4}$ : calcd $568.3470(\mathrm{M}+\mathrm{Cl})$, found 568.3664 . 


\section{1-(methyl(2-chloroethyl)carbonate)-7-(4'-(trans-3"'-(3"'-pyridyl)acrylamido)butyl)-}

1,7-dicarbadodecaborane (29). In a $10 \mathrm{~mL}$ round bottom flask under nitrogen, 11 (50 mg, 0.13 mmol) was dissolved in THF $(0.5 \mathrm{~mL})$ and Hünig's base $(46 \mu \mathrm{L}, 0.27 \mathrm{mmol})$ was added . Solution was cooled to $0{ }^{\circ} \mathrm{C}$ in an ice bath while stirring and 2-chloroethyl chloroformate $(28 \mu \mathrm{L}$, $0.27 \mathrm{mmol}$ ) was added drop wise. The reaction was allowed to stir overnight while reach ambient temperature. Reaction was quenched using $1 \mathrm{M} \mathrm{NH}_{4} \mathrm{Cl}_{(\mathrm{aq})}(2 \mathrm{~mL})$ and $\mathrm{Et}_{2} \mathrm{O}(2 \mathrm{~mL})$ was added. It was then transferred to a separatory funnel and the organic layer was separated. $\mathrm{Et}_{2} \mathrm{O}(2$ $\times 2 \mathrm{~mL})$ was used to extract again and combined organics were wash with saturated $\mathrm{NaHCO}_{3}(3$ $\mathrm{mL}$ ), brine (4 mL), dried on $\mathrm{MgSO}_{4}$, filtered, and concentrated, to afford $52 \mathrm{mg}$ of (29) as light orange oil (Yield: 83\%). The product was used without further purification and immediately used in the next step of the synthesis. HRMS (ESI, neg.) for $\mathrm{C}_{18} \mathrm{H}_{31} \mathrm{~B}_{10} \mathrm{ClN}_{2} \mathrm{O}_{4}$ : calcd 482.2888 (MH), found 482.2832.

\section{1-(methyl(2-azidoethyl)carbonate)-7-(4'-(trans-3"'-(3"'-pyridyl)acrylamido)butyl)-}

1,7-dicarbadodecaborane (30). In a $10 \mathrm{~mL}$ round bottom flask, (29) (57 mg, $0.12 \mathrm{mmol}$ ) was dissolved in DMF (1.5 mL). NaN 3 (77 mg, $1.2 \mathrm{mmol})$, and catalytic amount of $\mathrm{NaI}$ ( $2 \mathrm{mg}, 0.01$ mmol) was added and the mixture was refluxed at $60{ }^{\circ} \mathrm{C}$ while stirring overnight. The solution was cooled to room temperature, $\mathrm{Et}_{2} \mathrm{O}(3 \mathrm{~mL})$ was added and washed with $5 \% \mathrm{LiCl}_{(\mathrm{aq})}(3 \times 3$ $\mathrm{mL})$. Combined aq phase were re-extracted with $\mathrm{Et}_{2} \mathrm{O}(9 \mathrm{~mL})$, and all organic phase were combined and washed with brine (5 mL). Organic phase was then dried on $\mathrm{MgSO}_{4}$, concentrated, and purified using silica gel column chromatography using a gradient of MeOH:chloroform (2-10\%) to afford $20 \mathrm{mg}$ of (30) as yellow oil (Yield: 100\%). ${ }^{1} \mathrm{H}$ NMR (500 $\left.\mathrm{MHz}, \mathrm{CD}_{2} \mathrm{Cl}_{2}\right): \delta=8.75(\mathrm{~s}, 1 \mathrm{H}), 8.55(\mathrm{~s}, 1 \mathrm{H}), 7.84(\mathrm{~d}, J 7.5,1 \mathrm{H}), 7.56(\mathrm{~d}, J 15.5,1 \mathrm{H}), 7.35-7.32$ $(\mathrm{m}, 1 \mathrm{H}), 6.51(\mathrm{~d}, J 16.0,1 \mathrm{H}), 5.95(\mathrm{~s}, \mathrm{br}, 1 \mathrm{H}), 4.34(\mathrm{~s}, 2 \mathrm{H}), 4.29(\mathrm{t}, J 5.0,2 \mathrm{H}), 3.54(\mathrm{t}, J 5.0,2 \mathrm{H})$, 
$3.31(\mathrm{q}, J 6.5,2 \mathrm{H}), 1.99(\mathrm{t}, J 8.5,2 \mathrm{H}), 1.51-1.39(\mathrm{~m}, 4 \mathrm{H}), 2.9-1.55(\mathrm{~m}, 10 \mathrm{H}, \mathrm{B}-\mathrm{H}) .{ }^{13} \mathrm{C}$ NMR $\left(125.8 \mathrm{MHz}, \mathrm{CD}_{2} \mathrm{Cl}_{2}\right): \delta=165.18,154.15,150.28,149.26,137.15,134.84,131.35,124.20$, 123.57, 76.77, 72.31, 68.32, 67.23, 50.05, 39.56, 36.91, 29.55, 27.73. ${ }^{11} \mathrm{~B}\left\{{ }^{1} \mathrm{H}\right\}$ (dc) NMR $(96.3$ $\mathrm{MHz}, \mathrm{CD}_{2} \mathrm{Cl}_{2}$ ): $\delta=-5.97$ (1B), -7.69 (1B), -11.07 (6B), -14.05 (2B). HRMS (ESI, pos.) for $\mathrm{C}_{18} \mathrm{H}_{31} \mathrm{~B}_{10} \mathrm{~N}_{5} \mathrm{O}_{4}$ : calcd $490.3461(\mathrm{M}+\mathrm{H})$, found 490.3444 .

2-(2-azidoethoxy)acetic acid (31). In a $50 \mathrm{~mL}$ 2-neck round bottom flask, (20) (500 mg, $3.81 \mathrm{mmol})$ was dissolved in acetone $(5 \mathrm{~mL})$ and cooled to $0{ }^{\circ} \mathrm{C}$ in an ice bath. $\mathrm{CrO}_{3}(762 \mathrm{mg}$, $7.62 \mathrm{mmol}$ ) was dissolved in $1.5 \mathrm{M} \mathrm{H}_{2} \mathrm{SO}_{4(\mathrm{aq})}(7.62 \mathrm{~mL})$ and added to the reaction mixture drop wise. Ice bath was removed and the solution was stirred for 3 hours. Mixture was filtered and solvents were removed under reduced pressure. Crude was dissolved in $2 \mathrm{M} \mathrm{HCl}_{(\mathrm{aq})}(10 \mathrm{~mL})$ and extracted using EtOAc $(3 \times 15 \mathrm{~mL})$. Combined organics were dried on $\mathrm{MgSO}_{4}$, filtered, and concentrated. Crude product was further purified using a short neutral alumina plug using EtOAc to afford $406 \mathrm{mg}$ of product (31) as dark blue oil (Yield: 73\%). ${ }^{1} \mathrm{H}$ NMR (500 MHz, $\left.\mathrm{CDCl}_{3}\right)$ : $\delta=$ $10.17(\mathrm{~s}, \mathrm{br}, 1 \mathrm{H}), 4.21(\mathrm{~s}, 2 \mathrm{H}), 3.76(\mathrm{t}, J 4.8,2 \mathrm{H}), 3.47(\mathrm{t}, J 4.8,2 \mathrm{H}) .{ }^{13} \mathrm{C} \mathrm{NMR}(126 \mathrm{MHz}$, $\mathrm{CDCl}_{3}$ ): $\delta=175.57,70.79,68.35,51.02$. HRMS (ESI, pos.) for $\mathrm{C}_{4} \mathrm{H}_{7} \mathrm{~N}_{3} \mathrm{O}_{3}$ : calcd $145.0493(\mathrm{M})$, found 144.9862 .

2-(2-azidoethoxy)acetyl chloride (32). In a $50 \mathrm{~mL}$ 2-neck round bottom flask attached to a vacuum line equipped with a secondary trap, $(\mathbf{3 1})(78 \mathrm{mg}, 60 \mu \mathrm{L}, 0.54 \mathrm{mmol})$ was dissolved in DCM $(0.6 \mathrm{~mL})$ and DMF $(2 \mu \mathrm{L}, 0.03 \mathrm{mmol})$ was added as a catalyst. While stirring, thionyl chloride (78 $\mu \mathrm{L}, 1.1 \mathrm{mmol}$ ) was added and the reaction mixture was allowed to stir for 2 hours at room temperature. The vessel was evacuated under reduced pressure to remove solvent and any 
gaseous byproducts. This afforded quantitative amount of (32), which was used without further purifications.

\section{1-(methyl (2-(2-azidoethoxy)acetate) $)-7-\left(4^{\prime}-\left(\right.\right.$ trans $-3^{\prime \prime}-\left(3^{\prime \prime \prime}-\right.$} pyridyl)acrylamido)butyl)-1,7-dicarbadodecaborane (33). In a $10 \mathrm{~mL}$ round bottom flask under nitrogen, 11 (85 mg, $0.23 \mathrm{mmol})$ was dissolved in THF (1 mL) and added to (32) (88 mg, $0.54 \mathrm{mmol}$ ). Pyridine ( $43 \mu \mathrm{L}, 0.54 \mathrm{mmol}$ ) was dissolved in THF ( $1 \mathrm{~mL}$ ) and added to the reaction mixture drop wise. The reaction was allowed to stir overnight. $\mathrm{CHCl}_{3}(2 \mathrm{ml})$ was added to the reaction mixture and filtered over celite. Crude was concentrated, Hünig's base (5 drops) was added and purified using silica gel column chromatography using a gradient of $\mathrm{MeOH}: \mathrm{CHCl}_{3}(0-10 \%)$ to afford $83 \mathrm{mg}$ of (33) as yellow oil (Yield: $\left.73 \%\right) .{ }^{1} \mathrm{H} \mathrm{NMR}(500 \mathrm{MHz}$, $\left.\mathrm{CDCl}_{3}\right): \delta=8.76(\mathrm{~s}, \mathrm{br}, 1 \mathrm{H}), 8.57(\mathrm{~s}, \mathrm{br}, 1 \mathrm{H}), 7.80(\mathrm{~d}, J 7.5,1 \mathrm{H}), 7.61(\mathrm{~d}, J 16.0,1 \mathrm{H}), 7.33(\mathrm{dd}$, ${ }^{3} J$ 7.5, $\left.{ }^{4} J 5.0,1 \mathrm{H}\right), 6.47(\mathrm{~d}, J 15.5,1 \mathrm{H}), 5.86(\mathrm{~s}, \mathrm{br}, 1 \mathrm{H}), 4.35(\mathrm{~s}, 2 \mathrm{H}), 4.19(\mathrm{~s}, 2 \mathrm{H}), 3.75(\mathrm{t}, J 5.0$, 2H), $3.45(\mathrm{t}, J 5.0,2 \mathrm{H}), 3.35(\mathrm{q}, J 6.7,2 \mathrm{H}), 1.96(\mathrm{t}, J 8.3,2 \mathrm{H}), 1.50(\mathrm{p}, J 7.1,2 \mathrm{H}), 1.44-1.38(\mathrm{~m}$, 2H), 3.20-1.60 (m, 10H, B-H). $\left.{ }^{13} \mathrm{C} \mathrm{NMR} \mathrm{(125.8} \mathrm{MHz,} \mathrm{CDCl}_{3}\right): \delta=169.12,165.44,150.50$, $149.24,137.80,134.96,131.07,124.14,123.07,76.30,72.21,70.90,68.46,64.90,51.07,39.66$, 36.81, 29.50, 27.61 pm. HRMS (ESI, neg.) for $\mathrm{C}_{19} \mathrm{H}_{33} \mathrm{~B}_{10} \mathrm{~N}_{5} \mathrm{O}_{4}$ : calcd 539.3204 (M+Cl), found 539.3143 .

Carbamate prodrug with fluorophore (34). In a $10 \mathrm{~mL}$ round bottom flask, (28) (35 mg, $66 \mu \mathrm{mol})$ was dissolved in degassed DMSO (1 mL). Hünig's base (17 $\mu \mathrm{L}, 99 \mu \mathrm{mol})$ and PMDETA $(21 \mu \mathrm{L}, 99 \mu \mathrm{mol})$ were added to the reaction mixture. (23) $(30 \mathrm{mg}, 79 \mu \mathrm{mol})$ was dissolved in degassed DMSO (1 mL) and transferred to the reaction mixture. $\mathrm{CuI}(19 \mathrm{mg}, 99$ $\mu \mathrm{mol})$ was added and the mixture was sonicated for an hour in a sonication bath. EtOAc (18 $\mathrm{mL})$, and $\mathrm{EtO}_{2}(3 \mathrm{~mL})$ were added to the reaction mixture and the mixture was washed using DI 
$\mathrm{H}_{2} \mathrm{O}(2 \times 20 \mathrm{~mL})$. Combined aqueous phase were further extracted with $\mathrm{EtO}_{2}(20 \mathrm{~mL})$. The organic extracts were combined and washed with $5 \% \mathrm{Na}_{2} \mathrm{~S}_{2} \mathrm{O}_{3(\mathrm{aq})}(20 \mathrm{~mL})$, then with brine $(2 \times$ $25 \mathrm{~mL}$ ), dried on $\mathrm{MgSO}_{4}$, concentrated, and purified using silica gel column chromatography using a gradient of $\mathrm{MeOH}$ :chloroform (1-5\%) to afford $45 \mathrm{mg}$ of (34) as green/orange oil (Yield: $75 \%) .{ }^{1} \mathrm{H}$ NMR $\left(500 \mathrm{MHz}, \mathrm{CDCl}_{3}\right): \delta=8.76$ (s, br, $\left.1 \mathrm{H}\right), 8.56$ (s, br, $\left.1 \mathrm{H}\right), 8.52(\mathrm{~d}, J 8.5$, $1 \mathrm{H}), 8.23(\mathrm{~d}, J 8.5,1 \mathrm{H}), 8.20(\mathrm{~d}, J 7.5,1 \mathrm{H}), 7.84(\mathrm{~s}, 1 \mathrm{H}), 7.76(\mathrm{~d}, J 7.5,1 \mathrm{H}), 7.58(\mathrm{~d}, J 16.0,1 \mathrm{H})$, 7.517.47 (m, 2H), $7.29(\mathrm{~s}, \mathrm{br}, 1 \mathrm{H}), 7.16(\mathrm{~d}, J 7.5,1 \mathrm{H}), 6.55(\mathrm{~d}, J 15.5,1 \mathrm{H}), 6.42(\mathrm{~s}, \mathrm{br}, 1 \mathrm{H}), 5.93$ (s, br, 1H), $5.34(\mathrm{t}, J 4.8,2 \mathrm{H}), 3.56(\mathrm{~s}, \mathrm{br}, 1 \mathrm{H}), 4.70(\mathrm{~s}, \mathrm{br}, 2 \mathrm{H}), 4.53(\mathrm{t}, J 5.0,2 \mathrm{H}), 4.21(\mathrm{~s}, 2 \mathrm{H})$, $3.82(\mathrm{t}, J 5.0,2 \mathrm{H}), 3.59$ (t, $J 4.2,2 \mathrm{H}), 3.47(\mathrm{t}, J 5.0,4 \mathrm{H}), 3.41(\mathrm{t}, J 4.5,2 \mathrm{H}), 3.35-3.29(\mathrm{~m}, 4 \mathrm{H})$, 3.08-3.07 (m, 2H), $2.87(\mathrm{~s}, 6 \mathrm{H}), 1.92(\mathrm{t}, J$ 8.5, 2H), $1.48(\mathrm{p}, J 7.0,2 \mathrm{H}), 1.44-1.38(\mathrm{~m}, 2 \mathrm{H}), 2.70-$ $1.65(\mathrm{~m}, 10 \mathrm{H}, \mathrm{B}-\mathrm{H}) .{ }^{13} \mathrm{C} \mathrm{NMR}\left(125.8 \mathrm{MHz}, \mathrm{CDCl}_{3}\right): \delta=165.63,155.35,152.29,150.23,149.15$, $145.18,137.27,135.21,135.06,130.79,130.24,129.95,129.65,128.66,128.66,124.39,123.60$, $123.52,119.15,115.60,76.26,73.50,70.52,70.21,69.88,69.55,69.36,65.20,64.96,50.55$, 45.74, 43.38, 41.12, 39.64, 36.89, 29.33, 27.67. HRMS (ESI, pos.) for $\mathrm{C}_{39} \mathrm{H}_{60} \mathrm{~B}_{10} \mathrm{~N}_{8} \mathrm{O}_{8} \mathrm{~S}$ : calcd $910.5325(\mathrm{M}+\mathrm{H})$, found 910.5494 .

Carbonate prodrug with fluorophore (35). In a $10 \mathrm{~mL}$ round bottom flask, (30) (31 $\mathrm{mg}, 62 \mu \mathrm{mol})$ was dissolved in degassed DMSO (0.5 mL). Hünig's base $(12 \mu \mathrm{L}, 66 \mu \mathrm{mol})$ and PMDETA (14 $\mu \mathrm{L}, 66 \mu \mathrm{mol})$ were added to the reaction mixture. (23) $(23 \mathrm{mg}, 61 \mu \mathrm{mol})$ was dissolved in degassed DMSO $(1.0 \mathrm{~mL})$ and transferred to the reaction mixture. $\mathrm{CuI}(13 \mathrm{mg}, 66$ $\mu \mathrm{mol})$ was added and the mixture was sonicated for an hour in a sonication bath. EtOAc (10 $\mathrm{mL})$, and $\mathrm{EtO}_{2}(1 \mathrm{~mL})$ were added to the reaction mixture and the mixture was washed using DI $\mathrm{H}_{2} \mathrm{O}(3 \times 10 \mathrm{~mL})$. Combined aqueous phase were further extracted with EtOAc $(5 \times 10 \mathrm{~mL})$. The organic extracts were combined and washed with brine $(2 \times 25 \mathrm{~mL})$, dried on $\mathrm{MgSO}_{4}$, 
concentrated, and purified using silica gel column chromatography using a gradient of $\mathrm{MeOH}$ :chloroform (1-5\%) to afford $53 \mathrm{mg}$ of (35) as green/orange oil (Yield: 99\%). ${ }^{1} \mathrm{H}$ NMR $\left(500 \mathrm{MHz}, \mathrm{CDCl}_{3}\right): \delta=8.74(\mathrm{~s}, \mathrm{br}, 1 \mathrm{H}), 8.54(\mathrm{~s}, \mathrm{br}, 1 \mathrm{H}), 8.52(\mathrm{~s}, \mathrm{br}, 1 \mathrm{H}), 8.23,(\mathrm{~d}, J 9.0,1 \mathrm{H})$ $8.21(\mathrm{~d}, J 7.0,1 \mathrm{H}), 7.84(\mathrm{~s}, 1 \mathrm{H}), 7.77(\mathrm{~d}, J 8.0,1 \mathrm{H}), 7.58(\mathrm{~d}, J 16.0,1 \mathrm{H}), 7.50(\mathrm{t}, J 8.2,2 \mathrm{H}), 7.31-$ 7.29 (m, br, 1H), $7.17(\mathrm{~d}, J 7.5,1 \mathrm{H}), 6.61(\mathrm{t}, \mathrm{br}, J 5.2,1 \mathrm{H}), 6.56(\mathrm{~d}, J$ 15.5, 1H), $5.89(\mathrm{t}, \mathrm{br}, J$ 6.0, 1H), 4.70-4.68 (m, 4H), 4.59 (t, J 4.8, 2H), $4.26(\mathrm{~s}, 2 \mathrm{H}), 3.59-3.57$ (m, 2H), 3.45-3.43 (m, 2H), $3.41(\mathrm{t}, J 5.0,2 \mathrm{H}), 3.37$ (q, J 6.2, 2H), $3.08(\mathrm{q}, J 5.2,2 \mathrm{H}), 2.88(\mathrm{~s}, 6 \mathrm{H}), 1.95-1.92(\mathrm{~m}, 2 \mathrm{H}), 1.53-$ $1.48(\mathrm{~m}, 2 \mathrm{H}), 1.47-1.40(\mathrm{~m}, 2 \mathrm{H}), 2.70-1.40(\mathrm{~m}, \mathrm{br}, 10 \mathrm{H}, \mathrm{B}-\mathrm{H}) .{ }^{13} \mathrm{C}$ NMR $\left(126 \mathrm{MHz}, \mathrm{CDCl}_{3}\right): \delta=$ $165.61,153.97,152.24,149.72,148.68,145.61,136.99,135.53,135.27,130.77,130.24,129.97$, $129.68,128.69,128.13,124.20,123.92,123.55,119.21,115.63,114.29,76.54,72.04,70.51$, 69.93, 69.59, 68.32, 66.50, 64.88, 49.33, 45.77, 43.40, 39.58, 36.97, 29.32, 27.70. HRMS (ESI, pos.) for $\mathrm{C}_{37} \mathrm{H}_{55} \mathrm{~B}_{10} \mathrm{~N}_{7} \mathrm{O}_{8} \mathrm{~S}$ : calcd $867.4902(\mathrm{M}+\mathrm{H})$, found 867.5270 .

Ester prodrug with fluorophore (36). In a $10 \mathrm{~mL}$ round bottom flask, (33) (25 mg, 67 $\mu \mathrm{mol})$ was dissolved in degassed DMSO (0.5 mL). Hünig's base $(11.7 \mu \mathrm{L}, 67.4 \mu \mathrm{mol})$ and PMDETA (14.1 $\mu \mathrm{L}, 67.4 \mu \mathrm{mol})$ were added to the reaction mixture. (23) $(25 \mathrm{mg}, 67 \mu \mathrm{mol})$ was dissolved in degassed DMSO $(1 \mathrm{~mL})$ and transferred to the reaction mixture. CuI (13 mg, 67 $\mu \mathrm{mol})$ was added and the mixture was sonicated for an hour in a sonication bath. EtOAc (12 $\mathrm{mL})$, and $\mathrm{EtO}_{2}(8 \mathrm{~mL})$ were added to the reaction mixture and the mixture was washed using DI $\mathrm{H}_{2} \mathrm{O}(3 \times 10 \mathrm{~mL})$. The organic phase was washed with brine $(10 \mathrm{~mL})$, dried on $\mathrm{MgSO}_{4}$, concentrated, and purified using silica gel column chromatography using a gradient of $\mathrm{MeOH}$ :chloroform (2-10\%) to afford $35 \mathrm{mg}$ of (36) as green/orange oil (Yield: 60\%). ${ }^{1} \mathrm{H}$ NMR $\left(500 \mathrm{MHz}, \mathrm{CDCl}_{3}\right): \delta=8.78(\mathrm{~s}, \mathrm{br}, 1 \mathrm{H}), 8.51(\mathrm{~d}, J 8.5,1 \mathrm{H}), 8.23(\mathrm{~d}, J 8.5,1 \mathrm{H}), 8.20\left(\mathrm{dd},{ }^{3} J 7.5\right.$, $\left.{ }^{4} J 1.0,1 \mathrm{H}\right), 7.86(\mathrm{~s}, 1 \mathrm{H}), 7.75(\mathrm{~d}, J 8.0,1 \mathrm{H}), 7.58(\mathrm{~d}, J 15.5,1 \mathrm{H}), 7.49(\mathrm{t}, J 7.7,2 \mathrm{H}), 7.30(\mathrm{~s}, \mathrm{br}$, 
$1 \mathrm{H}), 7.16(\mathrm{~d}, J 7.5,1 \mathrm{H}), 6.54(\mathrm{~d}, J 16.0,1 \mathrm{H}), 6.47(\mathrm{t}, \mathrm{br}, J 5.2,1 \mathrm{H}), 5.88(\mathrm{t}, \mathrm{br}, J 5.7,1 \mathrm{H}), 4.66$ $(\mathrm{s}, 2 \mathrm{H}), 4.58(\mathrm{t}, J 5.0,2 \mathrm{H}), 4.29(\mathrm{~s}, 2 \mathrm{H}), 4.09(\mathrm{~s}, 2 \mathrm{H}), 3.95(\mathrm{t}, J 5.0,2 \mathrm{H}), 3.56-3.54(\mathrm{~m}, 2 \mathrm{H}), 3.41-$ $3.39(\mathrm{~m}, 2 \mathrm{H}), 3.37(\mathrm{t}, J 5.0,2 \mathrm{H}), 3.33(\mathrm{q}, J 6.7,2 \mathrm{H}), 3.07(\mathrm{q}, J 5.2,2 \mathrm{H}), 2.86(\mathrm{~s}, 6 \mathrm{H}), 1.92(\mathrm{t}, J$ 8.5, 2H), 1.51-1.45 (m, 2H), 1.42-1.36 (m, 2H), 2.80-1.63 (m, 10H, BH). ${ }^{13} \mathrm{C}$ NMR (126 MHz, $\left.\mathrm{CDCl}_{3}\right): \delta=168.91,165.62,152.24,150.16,149.08,145.09,137.27,135.31,134.99,130.71$, $130.19,129.92,129.59,128.66,128.09,124.55,123.56,123.50,119.16,115.56,114.23,76.42$, $72.09,70.52,70.15,69.76,69.51,68.40,64.93,64.82,50.52,45.73,43.37,39.55,36.83,29.32$, 27.65. HRMS (ESI, pos.) for $\mathrm{C}_{38} \mathrm{H}_{57} \mathrm{~B}_{10} \mathrm{~N}_{7} \mathrm{O}_{8} \mathrm{~S}$ : calcd $881.5059(\mathrm{M}+\mathrm{H})$, found 881.5225 . 


\section{Chapter 4 : Association Constant of $\beta$-Cyclodextrin with}

\section{Carboranes, Adamantane, and Their Derivatives Using}

\section{Displacement Binding Technique}

\subsection{Introduction}

Cyclodextrins (CDs) are cyclic oligosaccharides composed of six, seven, or eight units of $\alpha$-D-glucopyranoside forming $\alpha$-cyclodextrin $(\alpha$-CD), $\beta$-cyclodextrin $(\beta$-CD), and $\gamma$-cyclodextrin $(\gamma-\mathrm{CD})$, respectively. In solution, CDs exhibit a truncated cone shape and possess a hydrophobic cavity that varies in size, depending on the number of glucopyranoside units, as well as a hydrophilic outer surface owing to the large number of hydroxides presented outward. ${ }^{29}$ CDs have been extensively studied for their ability to form host-guest complexes with lipophilic molecules. The formation of such complexes have been used to increase the solubility and bioavailability of lipophilic drugs and their dissociation may be used to optimize drug delivery. ${ }^{29,72}$ Depending on the type of CDs and the size of the guest lipophilic molecule, they can form either a 1:1 or a 1:2 complex, where two CDs encapsulate a single guest molecule.

Dicarba-closo-dodecaboranes have been investigated as potential building blocks for pharmaceuticals. ${ }^{25} \mathrm{CBs}$ are extraordinarily hydrophobic. Owing to the hydridic nature of their boron-hydrogen bonds, they may interact with biomolecules through unique proton-hydride hydrogen bonds (dihydrogen bonds). ${ }^{1}$ In recent years, there has been a large interest in CBs due to their biomedical applications. They have been used as pharmacophores in development new drugs for variety of illnesses. ${ }^{25,73}$ Their high abundance of boron has also been an attractive scaffold for development of therapeutic agents used for boron neutron capture therapy (BNCT) ${ }^{74-78}$ It's ability to complex with $\beta$-CD has been utilized to develop host-guest systems 
such as connectors for bioactive surfaces. ${ }^{79}$ One potential drawback of utilizing CBs in drug design is a decrease in the bioavailability of such molecules due to their hydrophobicity. Both CBs and adamantane have been reported to bind to $\beta-\mathrm{CD}$ with high $\mathrm{K}_{\mathrm{a}}{ }^{\prime}$ (as high as $1 \times 10^{6} \mathrm{M}^{-1}$ for carborane derivatives, and $4.2 \pm 0.1 \times 10^{4}$ for adamantane derivatives). ${ }^{37,38,40,80} \beta$-CD has been shown to form a 1:1 complex with $o$-carborane. ${ }^{81}$ Depending on the conformation of $\beta$-CD, its interior cavity has a height of 8.81-5.03 $\AA$, top diameter of 7.92-5.28 $\AA$, and bottom diameter of 8.53-7.60 $\AA^{82}$ However, most literature report the interior cavity’s bottom diameter as 7.6-7.8 $\AA^{29,83}$ CBs have a diameter of $7.2 \AA$, while adamantane's diameter is $6.34 \pm 0.04 \AA{ }^{84,85}$ The structures of the CB isomers and adamantane are depicted in Figure 4.1.

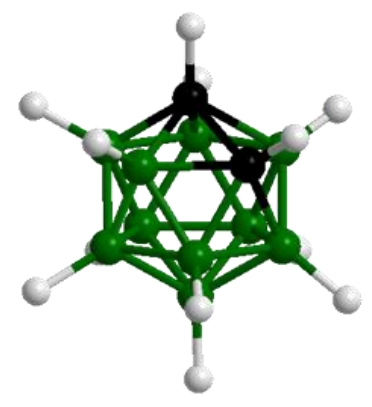

ortho-carborane

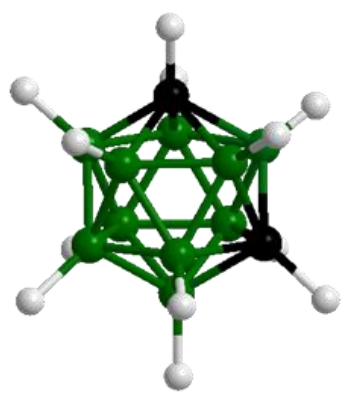

meta-carborane

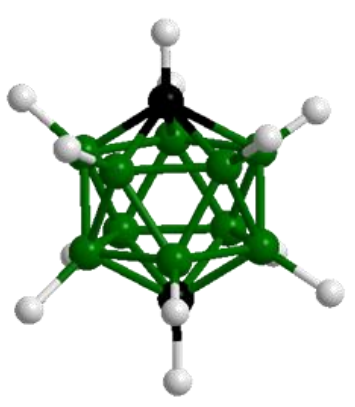

para-carborane

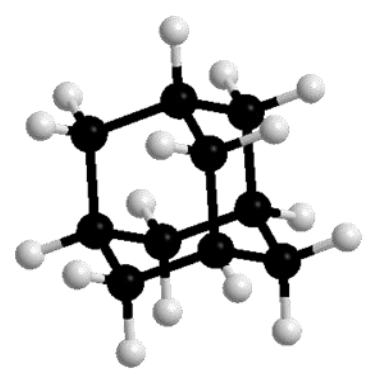

adamantane

$$
\begin{aligned}
& =B \\
O & =C \\
& =H
\end{aligned}
$$

Figure 4.1 - Ball and stick structure of carborane isomers and adamantine. 
It has been proposed that $o-\mathrm{CB}$ forms a 1:1 complex with $\beta-\mathrm{CD}$ due to its nearly perfect fit inside the hydrophobic cavity. ${ }^{81}$ In a separate study, phenyl-substituted CB was shown to form a robust 2:1 complex with $\beta-\mathrm{CD}{ }^{36}$ In order to avoid 2:1 complex formation, the species tested herein contain only one possible site for inclusion with $\beta-\mathrm{CD}$ and, in the examples of substituted species, only hydrophilic substituents were selected.

Before selecting the spectral displacement technique to measure the $\mathrm{K}_{\mathrm{a}}$ ' of the present species, other methods to measure the association constants and their limitations were studied. Some of the common methods to measure $\mathrm{K}_{\mathrm{a}}{ }^{\prime}$ include: NMR titration technique, spectral displacement technique, and isothermal titration calorimetry (ITC). The ITC technique was initially attempted by the authors for the present study. However, it was determined to be unsuitable, as the preparation of solutions of the host/guest molecules required various organic solvents; their mixture resulted in aberrant measurements due to the heat of solvation.

The NMR titration technique was rejected, as it necessitates the use of $\mathrm{D}_{2} \mathrm{O}$ as the solvent, in which both $\beta-\mathrm{CD}$ and the guest molecules have poor solubility under neutral conditions. This technique also requires the use of an internal standard. Such a technique may be inappropriate for measuring association constants for carborane and adamantane derivatives, as the magnitude of some of these species lie above the range appropriate for this technique: 10$10^{4} \mathrm{M}^{-1} .86$

For non-chromophoric guest molecules, spectral displacement technique can be utilized in presence of a competing chromophore. The absorptivity of the chromophore must change significantly between its bound and unbound states; ideally, it will be strongly absorbent in one state and non-absorbent in the other. The addition of analyte displaces some of the bound chromophore and the resulting change in absorptivity of the chromophore is measured. A 
sample spectra of demonstrating the change in absorptivity is illustrated in Figure 1.1. The association constant of the analyte may be calculated from the change in absorptivity of the chromophore and its known $\mathrm{K}_{\mathrm{a}}$ value. The specific equations used are introduced in the experimental section.

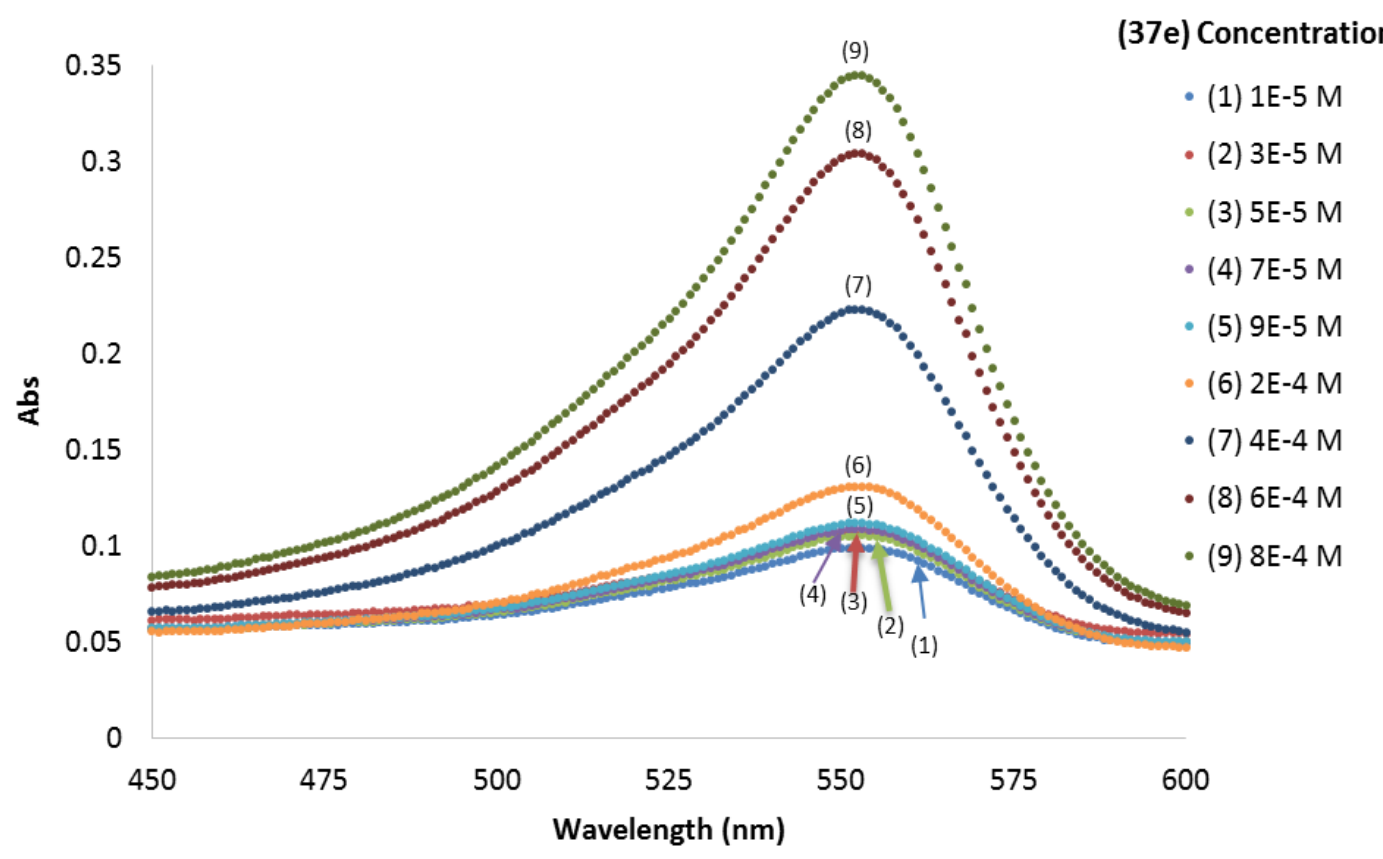

Figure 4.2 - Sample absorption spectra of PP at various concentrations of 37e in presence of $\beta$ $\mathrm{CD}$ at $22{ }^{\circ} \mathrm{C} .[\mathrm{PP}]_{0}=3 \times 10^{-5} \mathrm{M}$ and $[\beta-\mathrm{CD}]_{0}=2 \times 10^{-4} \mathrm{M}$, in $\mathrm{Na}_{2} \mathrm{CO}_{3}$ buffer $\left(4 \times 10^{-3} \mathrm{M}, \mathrm{pH}\right.$ $\approx 10.65)$.

To obtain accurate measurements using the spectral displacement technique, one must select a chromophore that possesses an equal, or higher, association constant than that of competing guest ${ }^{80}$. For the present study, the displaceable chromophore phenolphthalein (PP) 
was selected since its association constant with $\beta-\mathrm{CD}\left(3.46 \times 10^{4} \mathrm{M}^{-1}\right)$ is higher than those of any guest molecules that tested herein. The use of methyl orange was considered, however, its $\mathrm{K}_{\mathrm{a}}$ value $\left(3.24 \times 10^{3} \mathrm{M}^{-1}\right)$ is 10 -fold smaller than that of PP and its use would have resulted in erroneously high $\mathrm{K}_{\mathrm{a}}$ values for other guest molecules. A schematic representation of the displacement technique is illustrated in Scheme 4.1.

Scheme 4.1 - Schematic representation of the displacement technique using $\beta-C D, C B$, adamantane, and phenolphthalein.
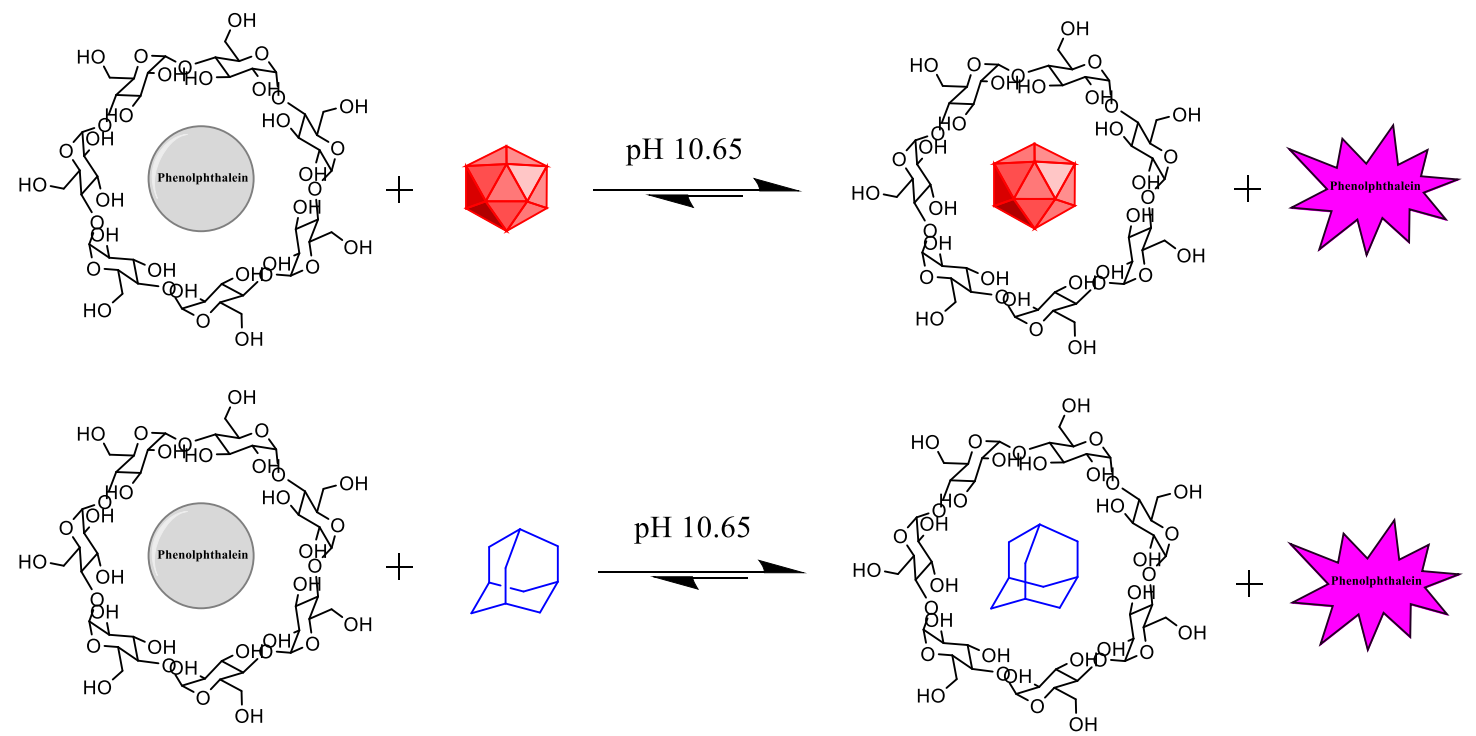

In order to ensure accurate results, the concentration of PP and the guest molecules were kept lower than that of $\beta$-CD to minimize the potential of 2:1 complex formation. This was also necessary, since most of the analytes tested were poorly soluble in aqueous solutions and their solubilization was only possible due to their inclusion within the cavity of $\beta$-CD. Higher 
concentrations of lipophilic analytes would precipitate or crystalize over time. The carborane derivatives utilized and the methods employed for their syntheses are depicted in Scheme 4.2.

Scheme 4.2 - Synthesis of carborane derivatives (37a-f). The meta isomers (38a-d) were synthesized in a similar fashion. ${ }^{87-89}$
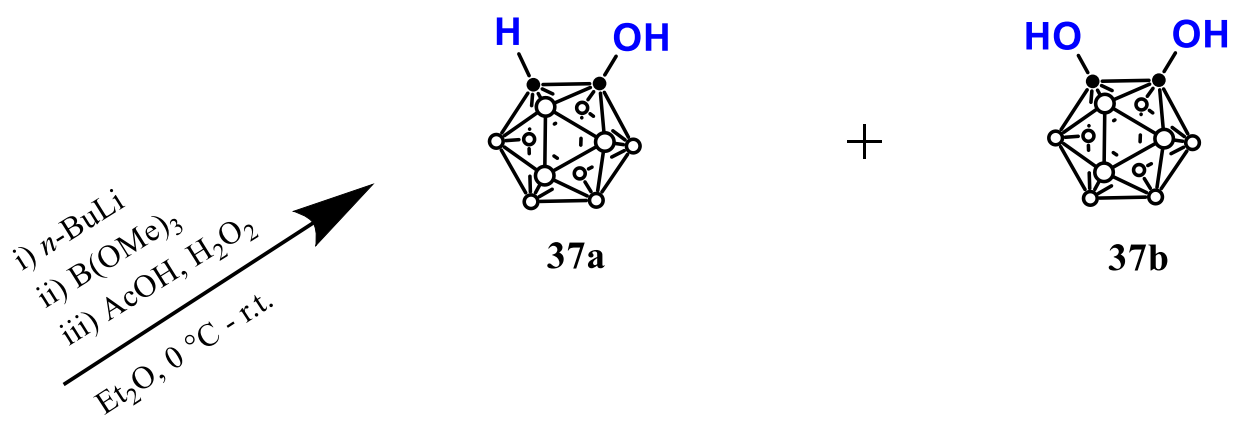

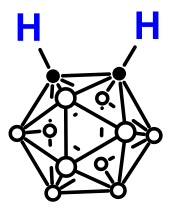

37

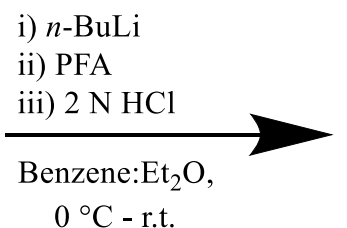

$0{ }^{\circ} \mathrm{C}-$ r.t.

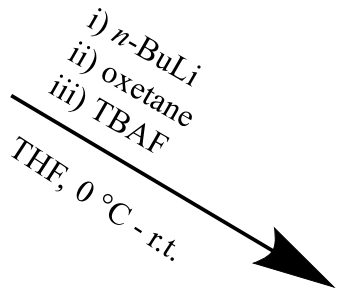

$0=\mathrm{BH}$

$\bullet=\mathrm{C}$

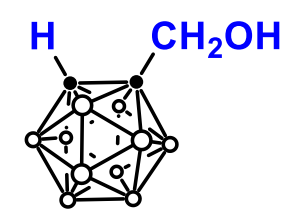

37c

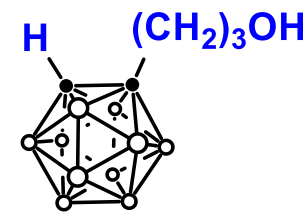

$37 \mathbf{e}$

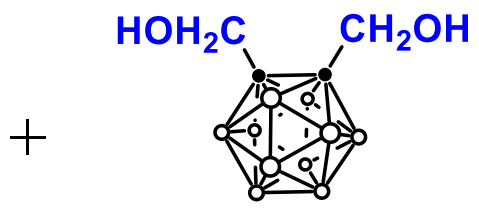

37d

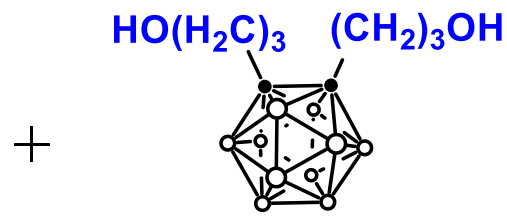

$37 f$

To utilize $\beta$-CD as a possible solubilizing agent and/or delivery vehicle for our CBcontaining drugs, we have also measured the $\mathrm{K}_{\mathrm{a}}{ }^{\prime}$ of 4 (MC4-PPE), a lipophilic molecule that contains a carborane moiety. A cartoon representation of a potential delivery vehicle for $\mathbf{4}$ is 
illustrated in Figure 4.3. The results obtained were compared against 12 (PhC4-PPEA). These molecules are structurally similar, and the only difference is that one contains a $m$-CB moiety at its distal end, while the other contains a phenyl group in the same position. The structure of these drug molecules are illustrated in Figure 4.4.
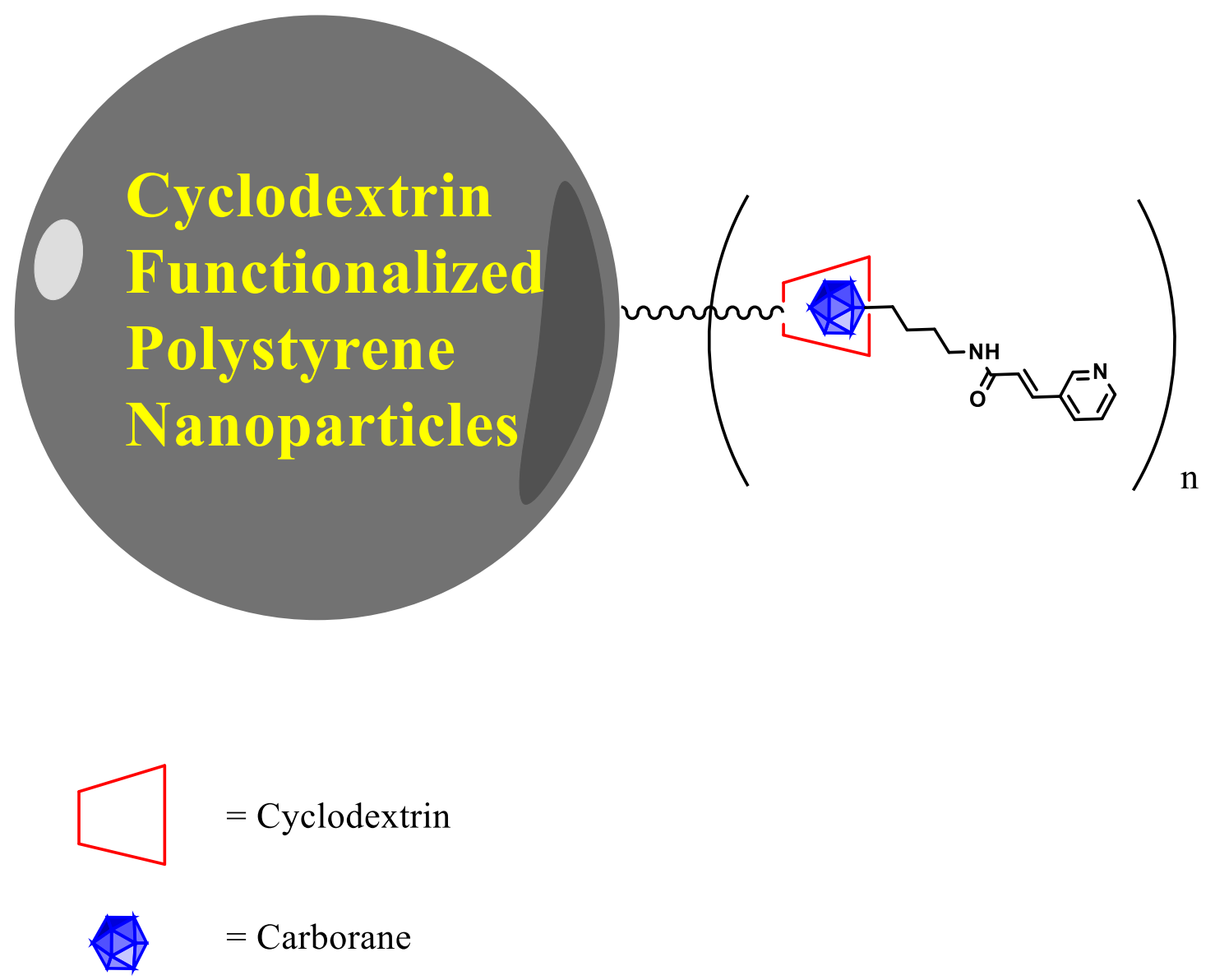

Figure 4.3 - Cyclodextrin functionalized polystyrene nanoparticles as possible delivery vehicles for carborane containing drugs. 


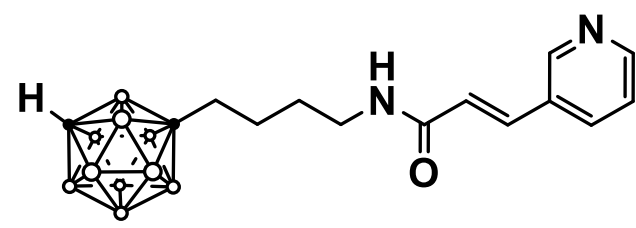

4<smiles>O=C(/C=C/c1cccnc1)NCCCCc1ccccc1</smiles>

12

Figure 4.4 - Molecular structure of 4 (MC4-PPEA), and 12 (PhC4-PPEA).

\subsection{Results and Discussion}

\subsubsection{Association constant $\left(K_{a}\right)$ of PP with $\beta$-CD}

To establish that $\beta-C D$ forms a 1:1 complex with PP, $\left(A_{0} / A\right)$ - 1 was plotted against $[\beta$ $\mathrm{CD}]_{0}$ (Figure 4.5). $\mathrm{A}_{0}$ and $\mathrm{A}$ are the peak absorbance of PP in absence and presence of $\beta-\mathrm{CD}$, respectively at $552 \mathrm{~nm}$, and $[\beta-\mathrm{CD}]_{0}$ is the total concentration of $\beta-\mathrm{CD}$. The linearity of the plot over the concentration range employed indicates that a 1:1 complex is formed. ${ }^{90}$ 


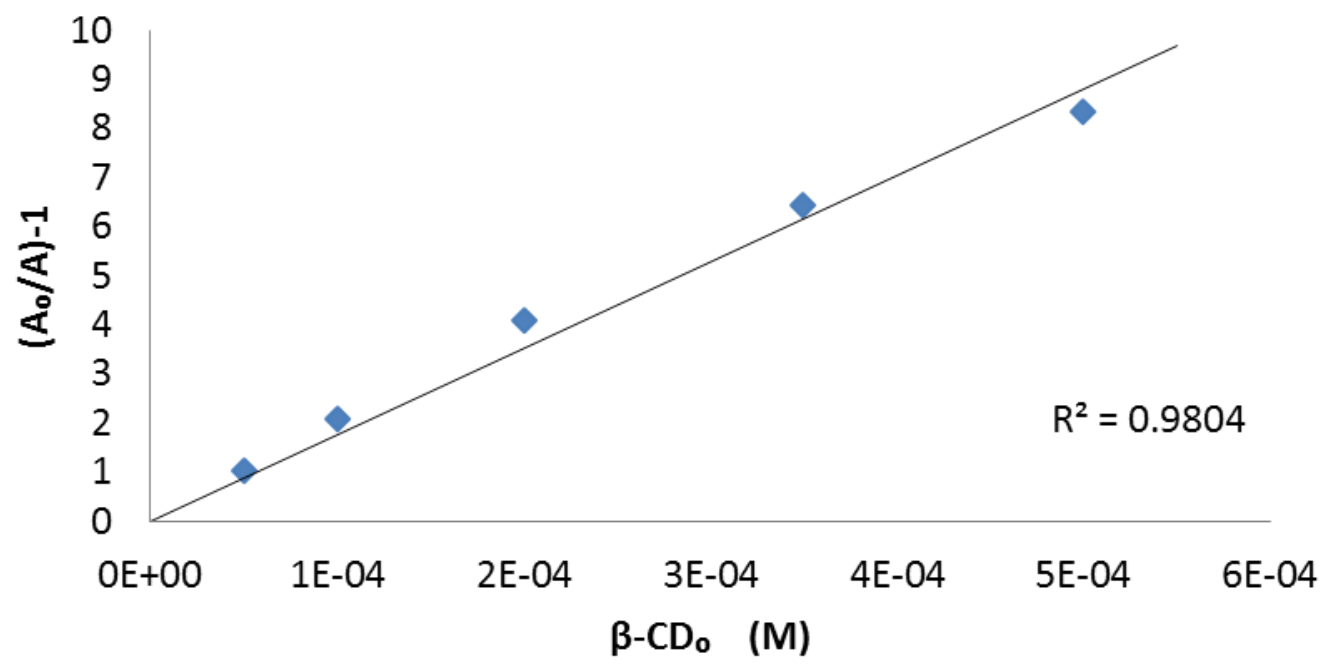

Figure 4.5 - Plot of $\left(\mathrm{A}_{0} / \mathrm{A}\right)-1$ against $\beta-\mathrm{CD}_{0}$ for PP: $\beta-\mathrm{CD}$ complex at $22{ }^{\circ} \mathrm{C}$. $[\mathrm{PP}]_{0}=3 \times 10^{-5} \mathrm{M}$ and $\beta-\mathrm{CD}=5 \times 10^{-5} \mathrm{M}-5 \times 10^{-4} \mathrm{M}$, in $\mathrm{Na}_{2} \mathrm{CO}_{3}$ buffer $\left(4 \times 10^{-3} \mathrm{M}, \mathrm{pH} \approx 10.65\right)$. The concentration of PP was determined by absorptivity at $552 \mathrm{~nm}$.

The association constant $\left(\mathrm{K}_{\mathrm{a}}\right)$ of PP with $\beta-\mathrm{CD}$ was then determined by plotting ([PP $]_{0}$ $[\mathrm{PP}]) /\left([\beta-\mathrm{CD}]_{0}-[\mathrm{PP}]_{0}+[\mathrm{PP}]\right)$ against $[\mathrm{PP}]$, and fitting the data to a linear equation, the slope of which is equal to $\mathrm{K}_{\mathrm{a}}\left(3.48 \times 10^{4} \mathrm{M}^{-1}\right)$ (Figure 4.6). Here $[\mathrm{PP}]_{0}$ is the total concentrations of PP, and $[\mathrm{PP}]$ is the concentration of non-complexed $\mathrm{PP}$, which was calculated using the calibration curve and its measured absorbance at $552 \mathrm{~nm}$. Our measured value of $\mathrm{K}_{\mathrm{a}}$ for PP is comparable to those found in literature which range from $3.4 \times 10^{4} \mathrm{M}^{-1}$ to $3.1 \times 10^{4} \mathrm{M}^{-1}$. 40,90 Others have reported values of $\mathrm{K}_{\mathrm{a}}$ for PP that were slightly lower; this may be due to the fact that those authors prepared their PP solution using ethanol and their mixed-solvent system contained 5\% ethanol. ${ }^{80,91}$ The inclusion of ethanol in those studies would also act as a competing guest, since ethanol is known to form an inclusion complex with $\beta-\mathrm{CD}$ and its association constant was reported to be $37.55 \mathrm{M}^{-1} .^{92}$ 


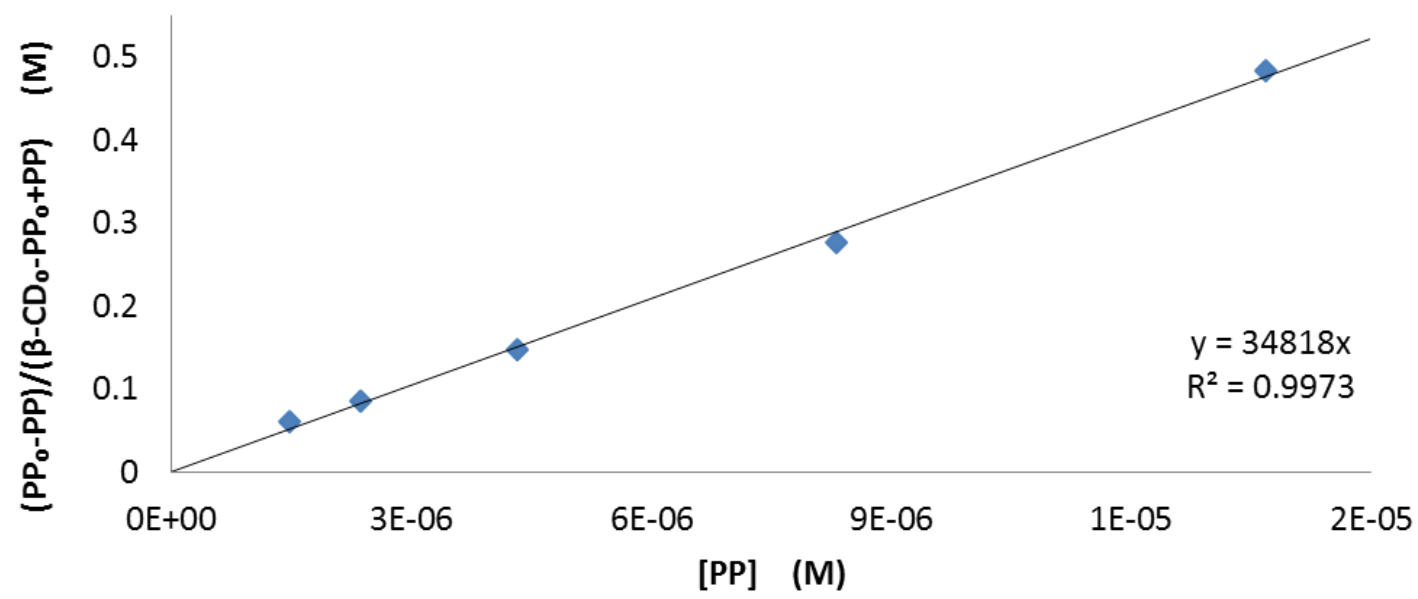

Figure 4.6 - Plot of $\left([\mathrm{PP}]_{0}-[\mathrm{PP}]\right) /\left([\beta-\mathrm{CD}]_{0}-[\mathrm{PP}]_{0}+[\mathrm{PP}]\right)$ against $[\mathrm{PP}]$ for $\beta-\mathrm{CD}: \mathrm{PP}$ complex at $22{ }^{\circ} \mathrm{C} .[\mathrm{PP}]_{0}=3 \times 10^{-5} \mathrm{M}$ and $\beta-\mathrm{CD}=5 \times 10^{-5} \mathrm{M}-6 \times 10^{-4} \mathrm{M}$, in $\mathrm{Na}_{2} \mathrm{CO}_{3}$ buffer $\left(4 \times 10^{-3} \mathrm{M}\right.$, $\mathrm{pH} \approx 10.65$ ). The concentration of PP was determined by absorptivity at $552 \mathrm{~nm}$.

\subsubsection{Association constant $\left(\mathrm{K}_{\mathrm{a}}{ }^{\prime}\right)$ of $\mathrm{CBs}$, adamantane, and their derivatives with $\beta-\mathrm{CD}$}

For the first time, we report the association constants for the unsubstituted carborane isomers, as well as for adamantane with $\beta$-cyclodextrin in an aqueous solution using the spectral displacement technique. Several derivatives of these molecules have also been investigated and their $\mathrm{K}_{\mathrm{a}}$ values determined (Figure 4.7). The results from this study are summarized in Table 4.1. Between the unsubstituted carborane isomers and adamantane, a trend is observed where $o$-CB has the highest $\mathrm{K}_{\mathrm{a}}{ }^{\prime}$ value followed by $m-\mathrm{CB}, p-\mathrm{CB}$, and adamantane respectively. Higher $\mathrm{K}_{\mathrm{a}}{ }^{\prime}$ values might be expected for carboranes as their nearly spherical shape may be complimentary to the inside cavity of $\beta-\mathrm{CD}$. They are also more hydrophobic than adamantane and would therefore have a higher affinity toward the comparably sized hydrophobic cavity of $\beta$-CD. 


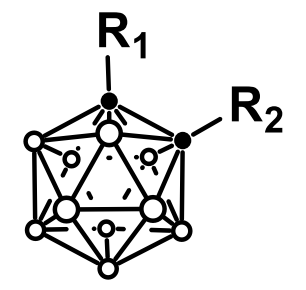

37

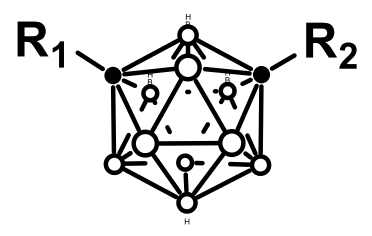

38

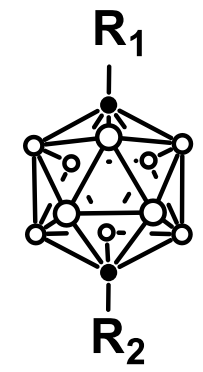

39

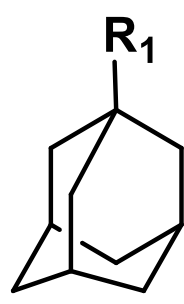

40

$$
\bullet=\mathrm{C} \quad \mathrm{O}=\mathrm{BH}
$$

Figure 4.7 - Carborane derivatives: ortho- (37), meta- (38), and para-carborane (39). Adamantine derivatives (40).

Table 4.1 - Association constant $\mathrm{K}_{\mathrm{a}}{ }^{\prime}\left(\mathrm{M}^{-1}\right)$ and the standard error of the estimate of carborane and adamantane derivatives with $\beta$-CD at $22{ }^{\circ} \mathrm{C}$, in $4 \mathrm{mM} \mathrm{Na}_{2} \mathrm{CO}_{3}$ buffer $(\mathrm{pH} 10.65)$

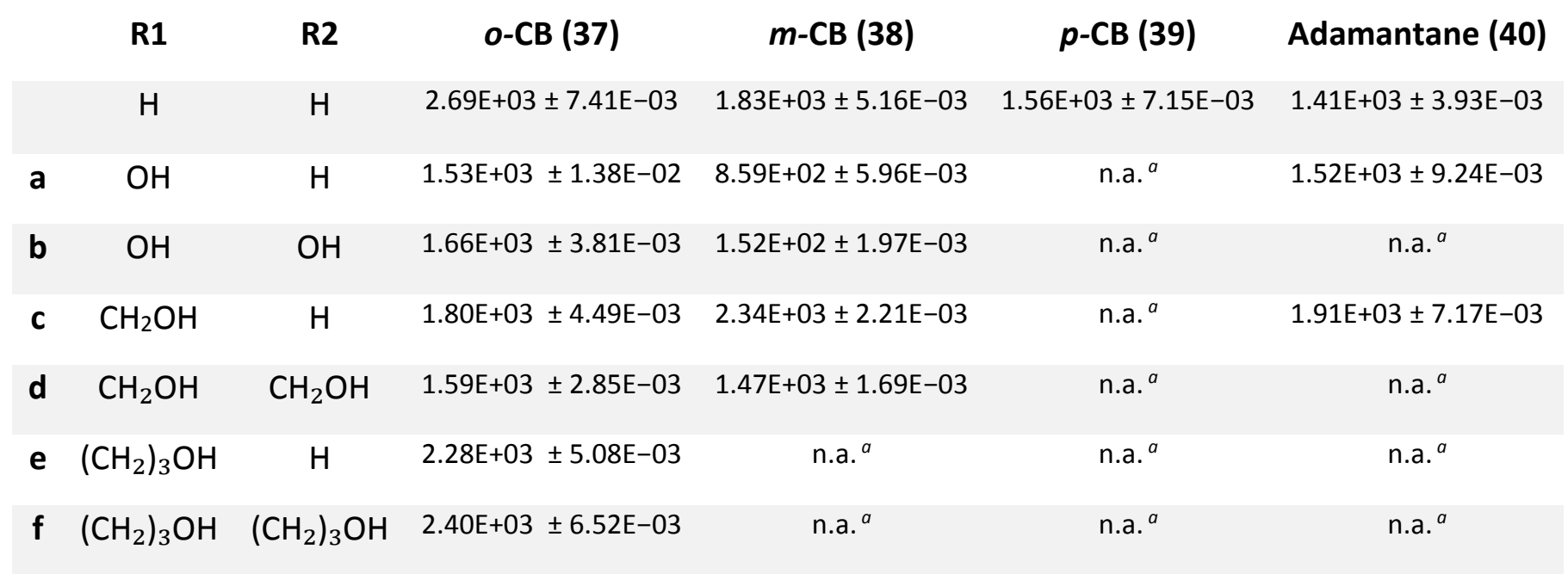

\footnotetext{
${ }^{a}$ not available
} 
Carboranes might also be expected to have higher $\mathrm{K}_{\mathrm{a}}{ }^{\prime}$ values than adamantane for entropic reasons. Carboranes have a rigid structure owing to their 26 extensively delocalized framework bonding electrons. ${ }^{73}$ In contrast, the structure of adamantane allows for increased bending and stretching of the $\mathrm{C}-\mathrm{C}$ bonds and the molecule has higher degrees of freedom in solution than carborane. The formation of an adamantane $\beta$-CD complex results in a larger decrease in entropy and is therefore entropically less favorable than the formation of a carborane $\beta-\mathrm{CD}$ complex.

Although the difference in $\mathrm{K}_{\mathrm{a}}{ }^{\prime}$ was not very large, the fact that $o$-CB exhibits the highest $\mathrm{K}_{\mathrm{a}}{ }^{\prime}$ value was unexpected as $p$-CB is the most hydrophobic of the three carborane isomers; followed by $m$-CB, with $o-\mathrm{CB}$ the least hydrophobic of the three. The trend of $\mathrm{K}_{\mathrm{a}}{ }^{\prime}$ values observed is opposite that of hydrophobicity. Given that the three carborane isomers are essentially identical in size and shape, their differences in dipole moment must account for the significantly different $\mathrm{K}_{\mathrm{a}}{ }^{\prime}$ values. $o$-CB has the highest dipole moment, followed by $m$-CB and then $p$-CB. ${ }^{73}$ Although these are the first accurately reported association constants for the three unsubstituted carborane isomers, this trend has been previously observed for their derivatives. ${ }^{37,38}$ The dipole moment unique to each $\mathrm{CB}$ isomer is owing to the differing locations of the two carbon atoms in each cage (Figure 4.1). Differences in the electronegativity of carbon and boron lead to different partial charges on these atoms and also on their respective bound hydrogen atoms. It is likely that these differences lead to more favorable interactions for some of the cage vertices with $\beta-\mathrm{CD}$, resulting in a specific orientation for each cage inside the cavity of $\beta-C D$, ultimately effecting their $\mathrm{K}_{\mathrm{a}}{ }^{\prime}$ values. ${ }^{37}$ 
The derivatives used in this study were mono- and di-substituted carborane and adamantane alcohols. Compound $\mathbf{3 8 b}$ was readily soluble in water and in comparison with most other carborane derivatives used in this study, was the most hydrophilic and thus exhibited the lowest $\mathrm{K}_{\mathrm{a}}{ }^{\prime}$ value. Other compounds that were readily soluble in the aqueous buffer also exhibited low $\mathrm{K}_{\mathrm{a}}{ }^{\prime}$ values. These include $37 \mathbf{a}, \mathbf{3 7 b}, \mathbf{3 8 a}$, and 40a, which were mono- and disubstituted hydroxyl derivatives. By distancing the hydrophilic functional group from the bulky lipophilic moiety by one carbon, all mono-substituted guest molecules experienced a slight increase in $\mathrm{K}_{\mathrm{a}}{ }^{\prime}(\mathbf{3 7 c}, \mathbf{3 8 c}, \mathbf{4 0 c})$. With the bulky hydrophobic $\mathrm{CB}$ or adamantane moiety occupying the inside the $\beta$-CD cavity, the hydroxy groups on $1 \mathrm{c}, 2 \mathrm{c}$, and $4 \mathrm{c}$ may be able to form hydrogen bonds with the hydroxy groups on the rim of $\beta-C D$, slightly increasing the $\mathrm{K}_{\mathrm{a}}{ }^{\prime}$ values. Along with the orientation of the substituents, this may explain the increase in $\mathrm{K}_{\mathrm{a}}{ }^{\prime}$ between $\mathbf{3 8}$ and 38c, as well as 40 and 40c. $K_{a}{ }^{\prime}$ values decreased for di-substituted derivatives 37d, and 38d. Having two hydroxyl groups increased the hydrophilicity and, as in the case of compound $\mathbf{3 8 b}$, this increased the solubility, resulting in a decreased value for $\mathrm{K}_{\mathrm{a}}{ }^{\prime}$.

The $\mathrm{K}_{\mathrm{a}}{ }^{\prime}$ for compounds $\mathbf{3 7 a - c}$ and 38a-c were previously reported. ${ }^{37,38}$ However, in those studies, the NMR titration technique utilizing neutral $\mathrm{D}_{2} \mathrm{O}$ at $30{ }^{\circ} \mathrm{C}$ was utilized. The reported value for compound $37 \mathrm{c}$ was $2.40 \times 10^{3} \mathrm{M}^{-1}$ which is very similar to our value $\left(2.34 \times 10^{3} \mathrm{M}^{-1}\right)$. However, the values reported for $\mathbf{3 7 a}, \mathbf{3 7 b}, \mathbf{3 8 a}$, and $\mathbf{3 8 b}$ were 20-30 fold larger, while the value reported for 37c was 4.5 times larger. In the previous studies, the authors claimed that it was not possible to determine $\mathrm{K}_{\mathrm{a}}{ }^{\prime}$ for unsubstituted $\mathrm{CB}$ derivatives due to poor solubility. The range of guest concentrations used in those studies was not apparent, but the authors presented a graph of NMR titrations of carborane alcohols, which indicated that the changes in chemical shifts plateaued after one equivalent of guest molecule to $\beta-\mathrm{CD}$ had been added. We suggest that the 
hydrogen bonding between the hydroxyl groups of $\beta-\mathrm{CD}$ and on the guest molecules, among other interactions, had an impact on the inclusion process. The authors of the previous study also stated that the value they measured for compound $\mathbf{3 7 b}\left(\mathrm{K}_{\mathrm{a}}{ }^{\prime}>1 \times 10^{6} \mathrm{M}^{-1}\right)$ was close to the limit of NMR titration method. However, previous studies have suggested that the NMR titration method is useful for the measurement of association constants that range between $10-10^{4} \mathrm{M}^{-1}{ }^{86}$ The values reported for $\mathbf{3 7 b}\left(\mathrm{K}_{\mathrm{a}}{ }^{\prime}=6.0 \times 10^{5} \mathrm{M}^{-1}\right), \mathbf{3 8 a}\left(\mathrm{K}_{\mathrm{a}}{ }^{\prime}=4.15 \times 10^{4} \mathrm{M}^{-1}\right)$, and $\mathbf{3 8 b}\left(\mathrm{K}_{\mathrm{a}}{ }^{\prime}=\right.$ $\left.2.53 \times 10^{4} \mathrm{M}^{-1}\right)$ were above this range. ${ }^{37,38}$

The effect of substituent carbon chain length was tested with compound 37e. Adding a lipophilic three-carbon long chain slightly increased $\mathrm{K}_{\mathrm{a}}{ }^{\prime}$ over that of $\mathbf{3 8 e}$. The addition of a second such lipophilic substituent in $\mathbf{3 7 f}$ caused an additional increase in $\mathrm{K}_{\mathrm{a}}{ }^{\prime}$. This can be explained by considering the ratio of $\mathrm{CH}_{2}$ to $\mathrm{OH}$ for each substituent, which is 3:1 for 37f, versus 1:1 for $\mathbf{3 7 d}$. The increased lipophilicity imparted by the hydrocarbon chains results in somewhat higher $\mathrm{K}_{\mathrm{a}}{ }^{\prime}$ values. It is also important to consider the effect of orientation of the ligands on CBs and the possible effect of hydrogen bonding between the hydroxy groups on the guest molecules with the hydroxy groups on $\beta-C D$.

The $\mathrm{K}_{\mathrm{a}}{ }^{\prime}$ values for compounds $37 \mathrm{e}$ and $\mathbf{3 7 f}$ had previously been reported $\left(\mathrm{K}_{\mathrm{a}}{ }^{\prime}\right.$ of $\mathbf{3 7 e}$ reported to be $1.14 \times 10^{5} \mathrm{M}^{-1}$ and $\mathbf{3 7 f}$ to be $\left.1.07 \times 10^{5} \mathrm{M}^{-1}\right) .{ }^{40}$ These values are approximately 20-fold larger than those reported here. In those studies, the authors reportedly used similar displacement technique using PP in 0.05 M borate buffer ( $\mathrm{pH}$ 10.5). However, no experimental data was provided, nor were the ranges of concentrations used for the guest molecules. Previous reports of high $\mathrm{K}_{\mathrm{a}}{ }^{\prime}$ values utilized concentrations of guest molecules higher than that of $\beta-\mathrm{CD}$, resulting in erroneously high $\mathrm{K}_{\mathrm{a}}{ }^{\prime}$ values. ${ }^{40}$ 


\subsection{3 $\mathrm{Ka}^{\prime}$ of drug molecules with $\beta-\mathrm{CD}$}

The $\mathrm{K}_{\mathrm{a}}{ }^{\prime}$ for MC4-PPEA, and PhC4-PPEA were obtained using the same techniques described previously. MC4-PPEA has shown to have a large inclusion constant $\mathrm{K}_{\mathrm{a}}{ }^{\prime}$ of $2.61 \times 10^{3}$ $\mathrm{M}^{-1}$. PhC4-PPEA, in comparison, showed $\mathrm{K}_{\mathrm{a}}{ }^{\prime}$ of $6.17 \times 10^{2} \mathrm{M}^{-1}$ which is over four times smaller. The structure of these two molecules are identical with the sole difference that one contains a $m$ $\mathrm{CB}$ at its distal end while other has a phenyl ring. We can safely conclude that the larger $\mathrm{K}_{\mathrm{a}}{ }^{\prime}$ obtained by MC4-PPEA is due to presence of a CB moiety. The high affinity of our drug toward $\beta$-CDs may result in the use of $\beta$-CDs as possible solubilizing agents as well as delivery vehicles.

\subsection{Conclusion}

The association constants for unsubstituted $o^{-}, m^{-}$, and $p$-carborane, as well as that of adamantane with $\beta-\mathrm{CD}$ are reported for the first time using the displacement binding technique in an aqueous solution under carefully controlled conditions. The $\mathrm{Ka}_{\mathrm{a}}$ 'values for these species are $2.69 \times 10^{3}, 1.83 \times 10^{3}, 1.56 \times 10^{3}$, and $1.41 \times 10^{3} \mathrm{M}^{-1}$, respectively, with o-CB exhibiting the highest $\mathrm{K}_{\mathrm{a}}{ }^{\prime}$ value. Previously reported $\mathrm{K}_{\mathrm{a}}{ }^{\prime}$ values for $\mathbf{3 7 b}, \mathbf{3 8 a}$, and $\mathbf{3 8 b}\left(6.0 \times 10^{5}, 4.15 \times 10^{4}\right.$, and $2.53 \times 10^{4} \mathrm{M}^{-1}$, respectively) were found to be erroneously high and instead equal $1.66 \times 10^{3}$, $8.59 \times 10^{2}$, and $1.52 \times 10^{2} \mathrm{M}^{-1}$, respectively. These new values are approximately 20 -fold smaller. The $\mathrm{K}_{\mathrm{a}}{ }^{\prime}$ for compound $\mathbf{3 7 e}$ and $\mathbf{3 7 f}$ were previously reported to be $1.14 \times 10^{5}$, and 1.07 $\times 10^{5} \mathrm{M}^{-1}$, respectively, but instead found to be $2.28 \times 10^{3}$, and $2.40 \times 10^{3} \mathrm{M}^{-1}$ (also approximately 20-fold smaller). Compound 4 (MC4-PPEA) had a $\mathrm{K}_{\mathrm{a}}{ }^{\prime}$ of $2.61 \times 10^{3} \mathrm{M}^{-1}$ while the $\mathrm{K}_{\mathrm{a}}{ }^{\prime}$ for 12 (PhC4-PPEA) was found to be $6.17 \times 10^{2} \mathrm{M}^{-1}$.

\subsection{Experimental}




\subsubsection{Materials}

$\beta-C D$ was purchased from Sigma-Aldrich and was further purified by recrystallizing three times. ${ }^{93}$ A water content of $13.9 \%$ was measured using thermogravimetric analysis (TGA). The $\beta$-CD was dried in a vacuum oven at $90{ }^{\circ} \mathrm{C}$ for one day, then stored in a vacuum desiccator in the presence of phosphorus pentoxide $\left(\mathrm{P}_{2} \mathrm{O}_{5}\right) . o-, m$-, and $p$-carborane $(o-\mathrm{CB}, m-\mathrm{CB}, p-\mathrm{CB})$ were purchased from Katchem Ltd., 1-adamantanemethanol (1Ad- $\mathrm{CH}_{2} \mathrm{OH}$ ), phenolphthalein (PP), n-butyllithium ( $n$-BuLi), trimethyl borate $\left.(\mathrm{B}(\mathrm{OMe}))_{3}\right)$, paraformaldehyde (PFA), oxetane, tetra- $n$-butylammonium fluoride (TBAF), sodium carbonate $\left(\mathrm{Na}_{2} \mathrm{CO}_{3}\right)$, glacial acetic acid $(\mathrm{AcOH}), 37 \%$ hydrochloric acid $(\mathrm{HCl}), 30 \%$ hydrogen peroxide $\left(\mathrm{H}_{2} \mathrm{O}_{2}\right)$, and all solvents were purchased from Sigma-Aldrich. Adamantane (Ad), 1-adamantanol (1Ad-OH) were purchased from Acros Organics. All organic solvents were dried over $3 \AA$ molecular sieves $(20 \% \mathrm{~m} / \mathrm{v})$ for at least 3 days. ${ }^{57}$ All chemicals were used without further modifications, unless stated otherwise. Triply distilled water was used throughout these studies.

\subsubsection{General preparation, and instruments}

Using $\mathrm{Na}_{2} \mathrm{CO}_{3}$ buffer $\left(4 \times 10^{-3} \mathrm{M}, \mathrm{pH} \approx 10.65\right)$, a stock solution of $\mathrm{PP}\left(1.5 \times 10^{-3} \mathrm{M}\right)$ was prepared. This stock solution was then used to make a series of dilutions ranging from $3 \times 10^{-6} \mathrm{M}$ to $3 \times 10^{-5} \mathrm{M}$ PP. A buffer system with $\mathrm{pH}$ of $9.5-10.5$ is typically utilized since PP in basic aqueous solutions has a fuchsia color, the absorption of which is measurable in the visible region using a spectrophotometer. ${ }^{40,94}$ Since PP has low solubility in water, a slightly higher $\mathrm{pH} 10.65$ was used so that the use of ethanol or other organic solvents, which interfere with the results, may be avoided. Solution absorptivity was measured at $552 \mathrm{~nm}$ using a Varian CARY 300 Conc $\mathrm{UV}-$ Visible spectrophotometer at ambient temperature $\left(22^{\circ} \mathrm{C}\right)$. A calibration curve was 
prepared to measure the concentration of free PP in solution (Figure 4.8). Each prepared sample was sonicated for 20 seconds using SONICS vibra-cell probe at $20 \mathrm{kHz} \pm 50 \mathrm{~Hz}$ at $40 \%$ amplitude which mildly heated the solutions. These solutions were allowed to reach ambient temperature before spectroscopic measurements were made. The procedure and the calculations described below are very similar to those described elsewhere. ${ }^{91}$ NMR spectra were recorded on Bruker DRX300, DRX500, AVANCE III 400 and AVANCEE II 500 Nuclear Magnetic Spectrometers. Spectrometers and analyzed using TopSpin. Chemical shifts $(\delta, \mathrm{ppm})$ for ${ }^{1} \mathrm{H}$ and ${ }^{13} \mathrm{C}$ were referenced to residual solvent peaks. Mass spectra were measured using a Mariner Biospectrometry time of flight spectrometer by PerSeptive Biosystems, equipped with electrospray ionization operating under both positive and negative modes and reported in $\mathrm{m} / \mathrm{z}$.

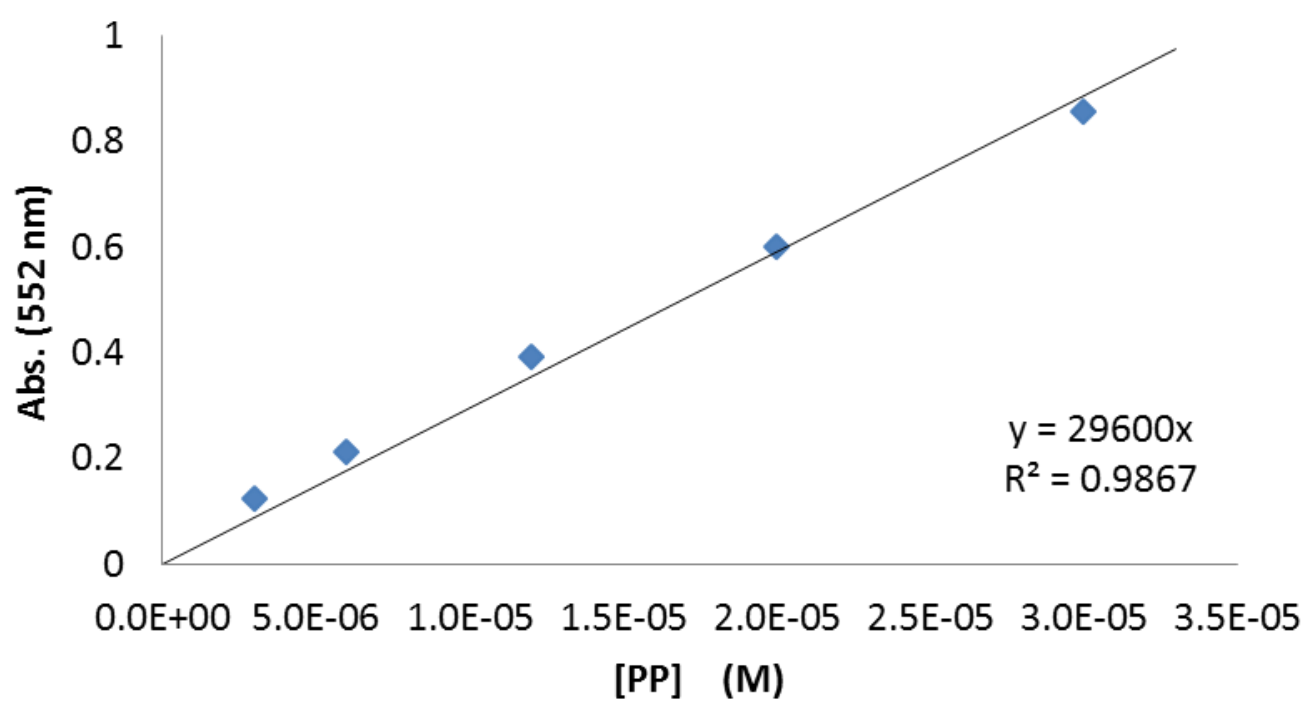

Figure 4.8 - Calibration curve for PP solution measured at $552 \mathrm{~nm}$. $[\mathrm{PP}]=3 \times 10^{-6} \mathrm{M}-3 \times 10^{-5}$ $\mathrm{M}$, in $\mathrm{Na}_{2} \mathrm{CO}_{3}$ buffer $\left(4 \times 10^{-3} \mathrm{M}, \mathrm{pH} \approx 10.65\right)$ at $22{ }^{\circ} \mathrm{C}$.

\subsubsection{Association constant (Ka) of PP with $\beta$-CD}


To measure the $\mathrm{K}_{\mathrm{a}}$ of PP with $\beta-\mathrm{CD}$, a series of solutions in $\mathrm{Na}_{2} \mathrm{CO}_{3}$ buffer were made, keeping the concentration of PP constant at $\left(3 \times 10^{-5} \mathrm{M}\right)$, while varying the concentration of $\beta$ $\mathrm{CD}$ between $5 \times 10^{-5} \mathrm{M}$ to $6 \times 10^{-4} \mathrm{M}$. The $\mathrm{K}_{\mathrm{a}}$ was calculated using the following equation:

$$
\mathrm{Ka}=\frac{[\mathrm{PP}]_{0}-[\mathrm{PP}]}{[\mathrm{PP}]\left([\beta-\mathrm{CD}]_{0}-[\mathrm{PP}]_{0}+[\mathrm{PP}]\right)}
$$

Using least squares analysis, the slope of the graph obtained provided a value for $\mathrm{K}_{\mathrm{a}}$.

\subsubsection{Association constant $\left(\mathrm{Ka}^{\prime}\right)$ of guest molecules with $\beta$-CD}

Assuming 1:1 complexations of both PP and guest molecule $(\mathrm{G})$ with $\beta$-CD and no interaction between the PP and $\mathrm{G}$, the total concentration of the host ([$\left.\beta-\mathrm{CD}]_{0}\right)$, chromophore $\left([\mathrm{PP}]_{0}\right)$, and guest $\left([\mathrm{G}]_{0}\right)$ molecule may be calculated using the following equations:

$$
\begin{gathered}
{[\beta-\mathrm{CD}]^{0}=[\beta-\mathrm{CD}]+\mathrm{Ka}[\beta-\mathrm{CD}]_{0}[\mathrm{PP}]+\mathrm{Ka}^{\prime}[\beta-\mathrm{CD}][\mathrm{G}]} \\
{[\mathrm{PP}]_{0}=[\mathrm{PP}]+\mathrm{Ka}[\beta-\mathrm{CD}][\mathrm{PP}]} \\
{[\mathrm{G}]_{0}=[\mathrm{G}]+\mathrm{Ka}^{\prime}[\beta-\mathrm{CD}][\mathrm{G}]}
\end{gathered}
$$

Where $[\mathrm{G}]$ and $[\beta-\mathrm{CD}]$ are the non-complexed concentrations of guest molecule and $\beta-\mathrm{CD}$, respectively. $\mathrm{K}_{\mathrm{a}}{ }^{\prime}$, and $\mathrm{K}_{\mathrm{a}}$ are the association constants of the guest molecule and PP, respectively. Since $[\mathrm{PP}]$ is the only value that can be measured spectroscopically, these equations may be 
rearranged so that $\mathrm{K}_{\mathrm{a}}$ ' may be calculated based on the known initial concentrations, $[\mathrm{PP}]$, and $\mathrm{K}_{\mathrm{a}}$ using the following equation:

$$
\mathrm{K}_{\mathrm{a}}{ }^{\prime}=\frac{\left\{\frac{\mathrm{Ka}[\mathrm{PP}]\left([\mathrm{[B}-\mathrm{CD}]^{0}-[\mathrm{PP}]^{0}+[\mathrm{PP}]\right)}{[\mathrm{PP}]^{0}-[\mathrm{PP}]}\right\}-1}{\frac{\left.\mathrm{G}]_{0}-[\beta-\mathrm{CD}]_{0}+(\mathrm{PP}]_{0}-[\mathrm{PP}]\right)(\mathrm{Ka}[\mathrm{PP}]+1)}{\mathrm{Ka}[\mathrm{PP}]}}
$$

Using least squares analysis, the slope of the linear fragment of a plot of equation 5 will equal $\mathrm{K}_{\mathrm{a}}{ }^{\prime}$ (Figure 4.9Figure 4.10Figure 4.11Figure 4.12, andFigure 4.13). Precipitation was observed when the concentration of lipophilic analytes were higher than that of $\beta$-CD, resulting in nonlinear plots. This behavior was not observed for analytes that were readily soluble in the buffer. In order to avoid precipitation, the concentrations of all guest molecules were maintained below that of $\beta-\mathrm{CD}$ and ranged between (1-9) $\times 10^{-5} \mathrm{M}$. Only concentrations where all components remained in solution were considered. All guest molecules were stable in alkaline buffer (pH 10.65). 


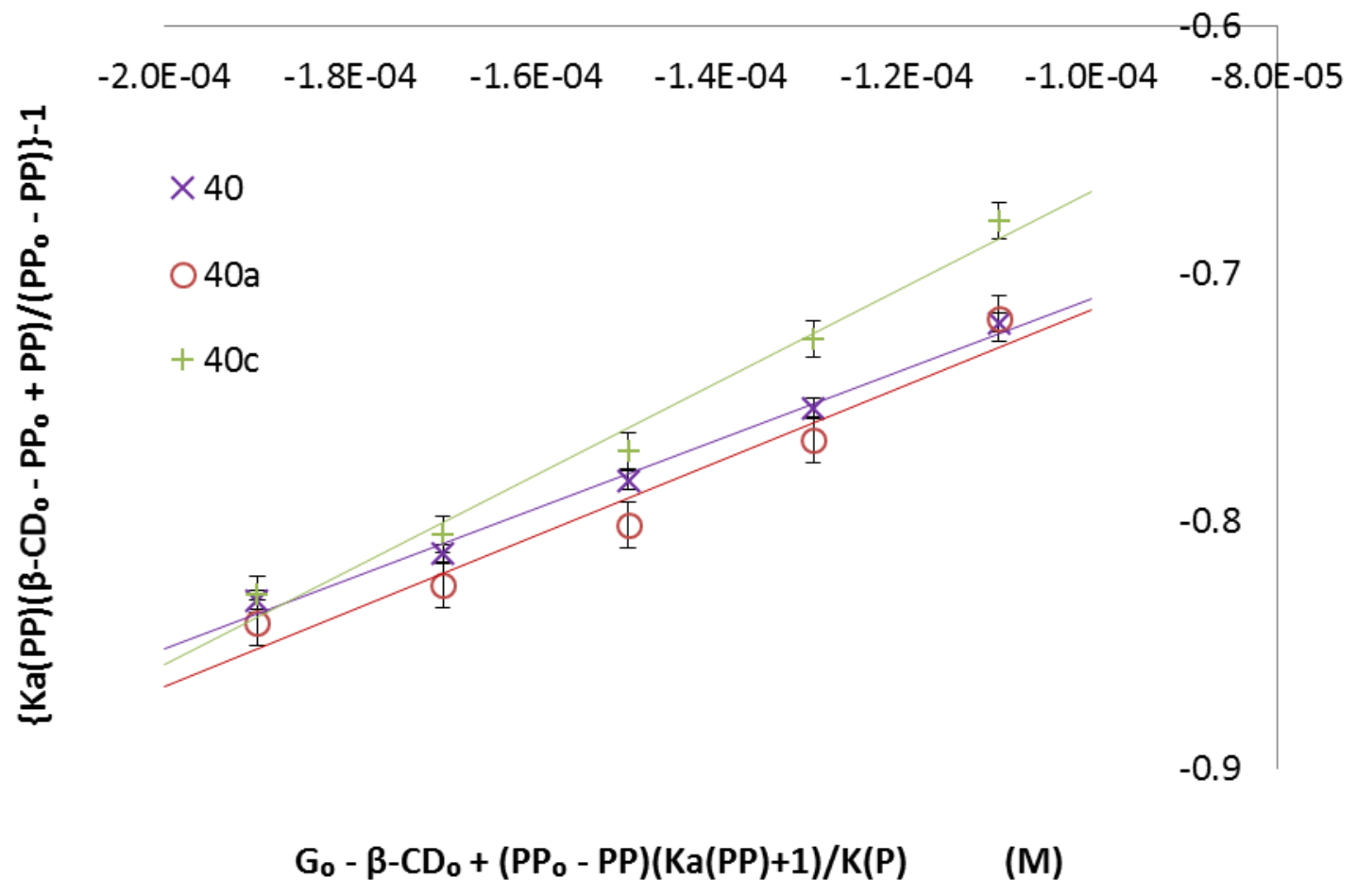

Figure 4.9 - Experimental data for 4, 4a, and 4c fitted to equation (5). 


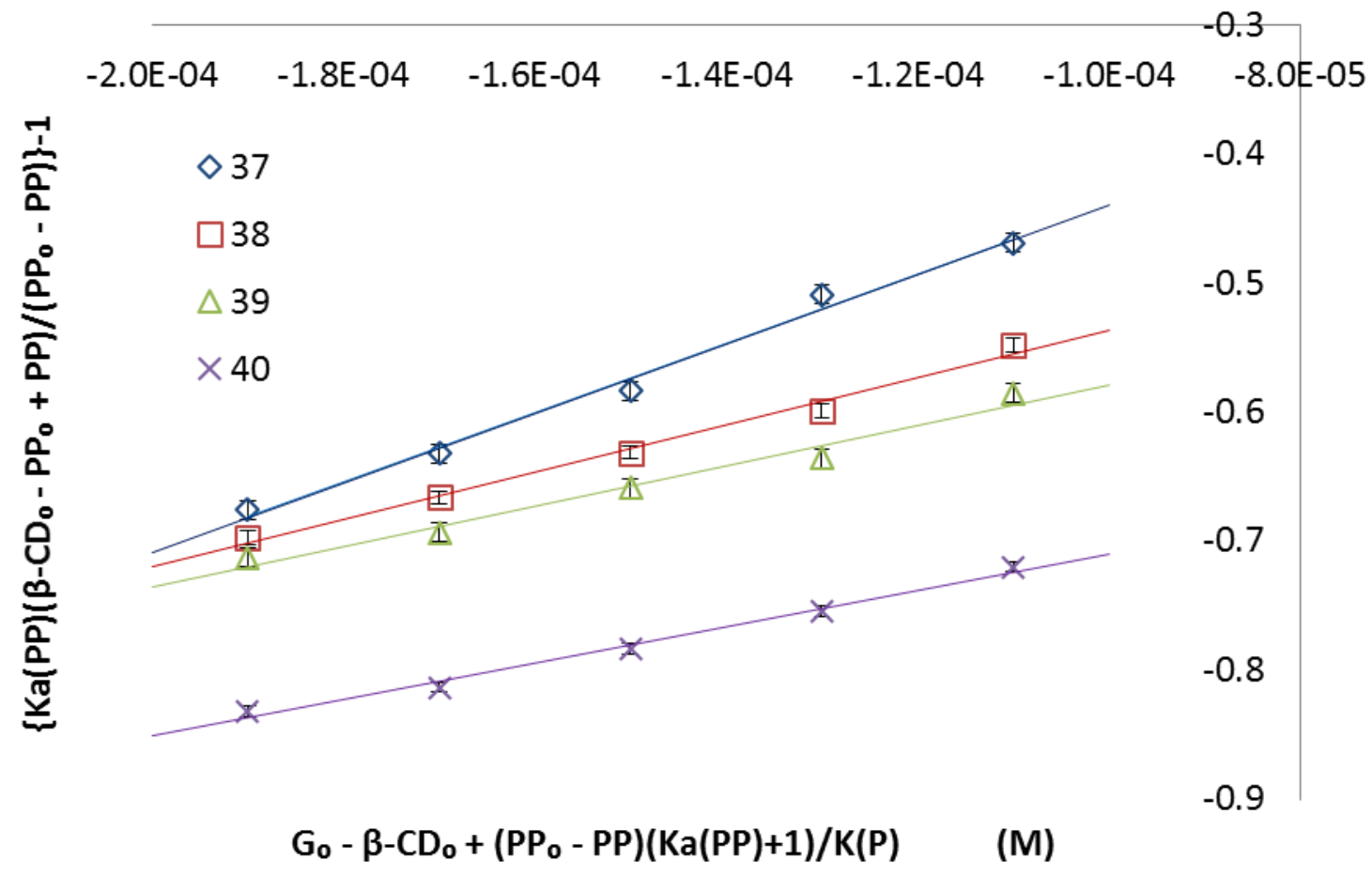

Figure 4.10 - Experimental data for 37, 38, 39, and 40 fitted to equation (5). 


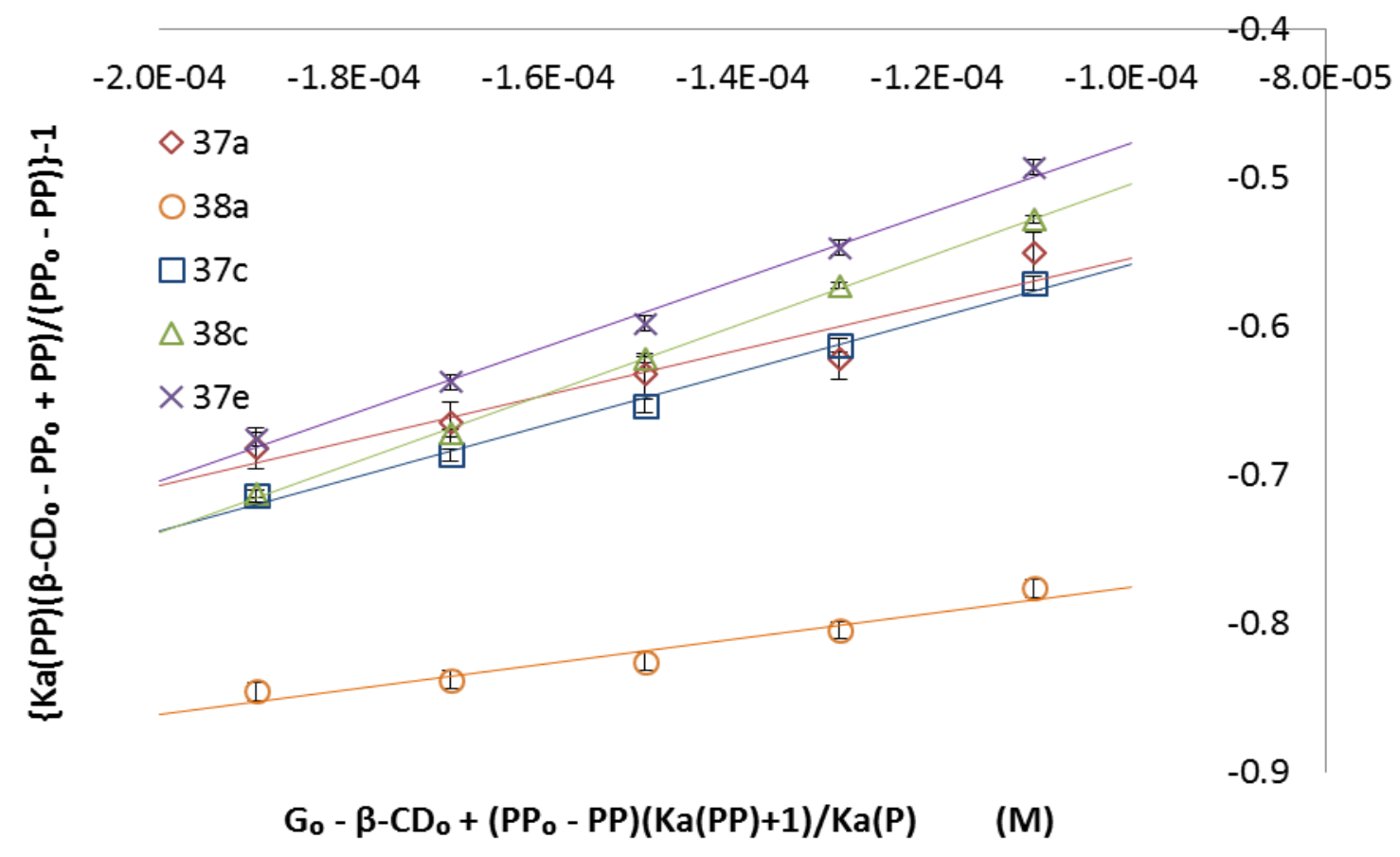

Figure 4.11 - Experimental data for 37a, 38a, 37c, 38c, and 37e fitted to equation (5). 


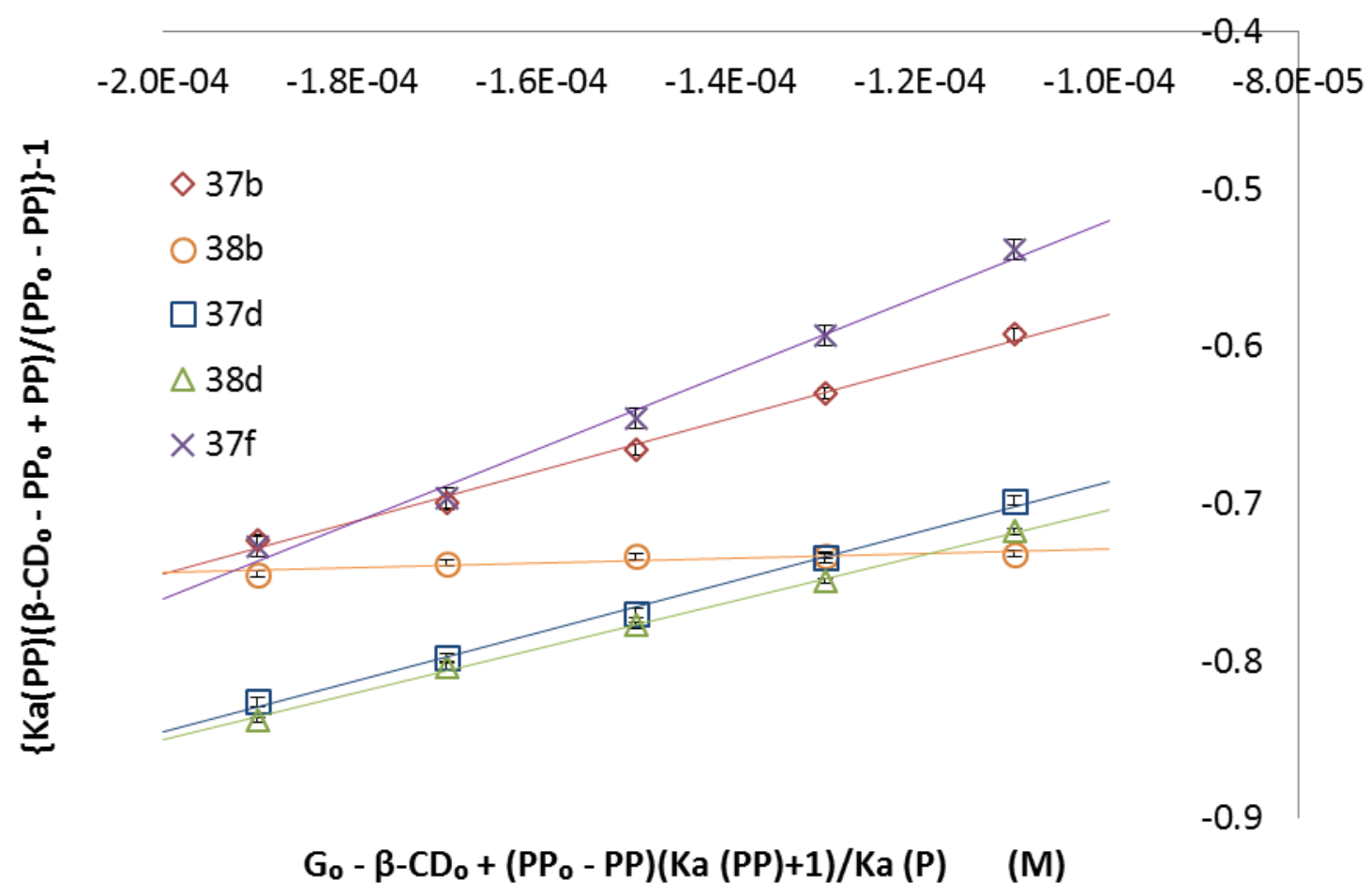

Figure 4.12 - Experimental data for $\mathbf{3 7 b}, \mathbf{3 8 b}, \mathbf{3 7 d}, \mathbf{3 8 d}$, and 37f fitted to equation (5). 


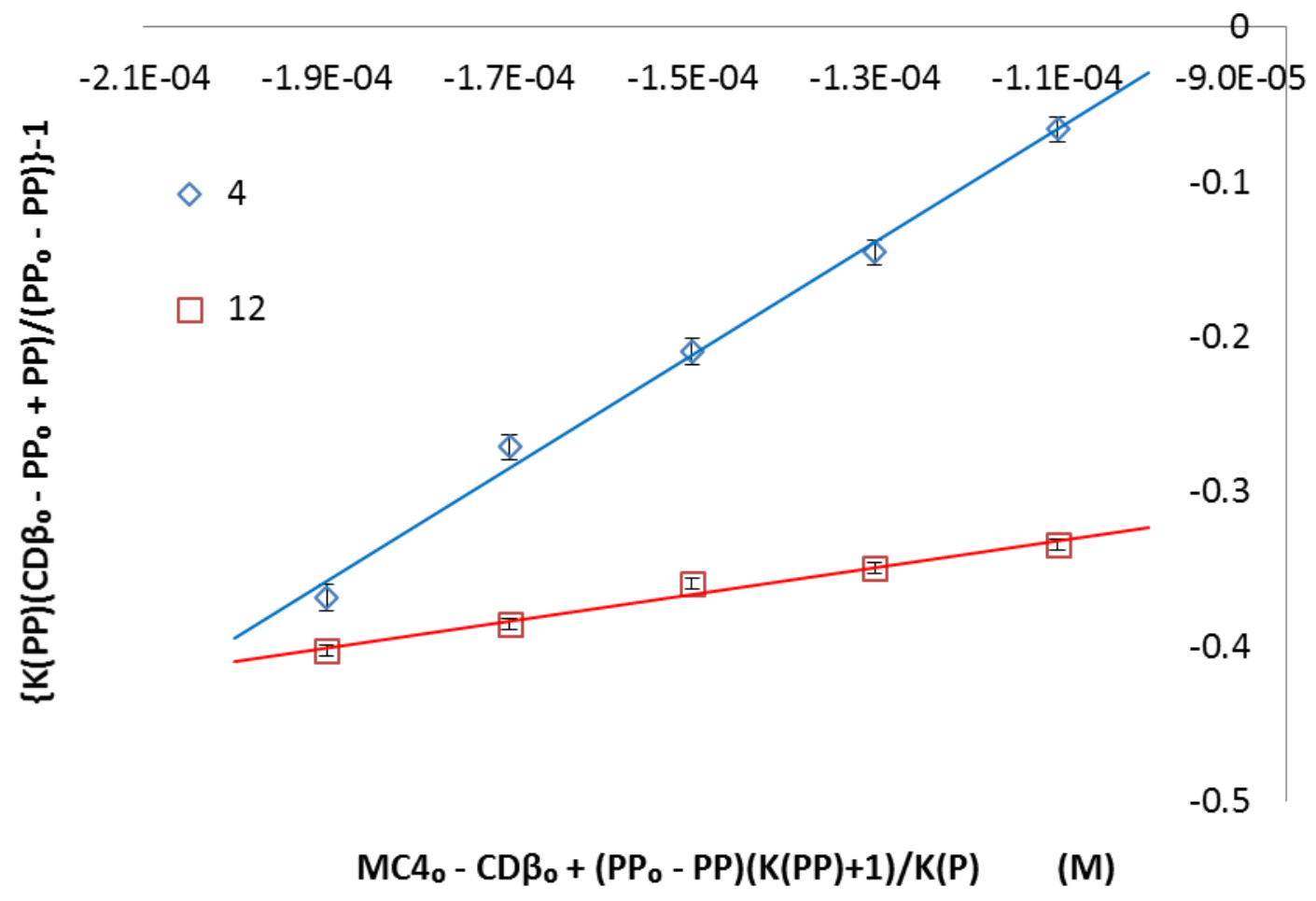

Figure 4.13 - Experimental data for drugs 4, and 12 fitted to equation (5).

\subsubsection{Procedure for the synthesis of carborane derivatives}

\section{1-(hydroxy)-1,2-dicarbadodecaborane (37a) and bis-(hydroxy)-1,2-}

dicarbadodecaborane (37b) ${ }^{87} \mathrm{In}$ a $25 \mathrm{~mL}$ 2-neck round bottom flask, $o$-carborane (300 $\mathrm{mg}$, $2.08 \mathrm{mmol}$ ) was dissolved in anhydrous THF $(5 \mathrm{~mL})$. The solution was cooled to $0{ }^{\circ} \mathrm{C}$ in an ice bath while stirring, and $2.4 \mathrm{M} n$-butyllithium in hexane $(1.75 \mathrm{~mL}, 4.37 \mathrm{mmol})$ was added drop wise. The reaction mixture was allowed to stir for 1.5 hours while reaching ambient temperature. It was then cooled to $-30{ }^{\circ} \mathrm{C}$ and neat trimethyl borate $(0.58 \mathrm{~mL}, 5.2 \mathrm{mmol})$ was added all at once. The reaction mixture was allowed to be warmed to $0{ }^{\circ} \mathrm{C}$, over one hour period. $30 \% \mathrm{H}_{2} \mathrm{O}_{2}$ 
$(2 \mathrm{~mL})$ and acetic acid $(2 \mathrm{~mL})$ were added slowly. The reaction mixture was stirred at room temperature for 22 hours and saturated $\mathrm{NaHSO}_{3}(6 \mathrm{~mL})$ and $10 \% \mathrm{NaOH}$ solution $(9 \mathrm{~mL})$ were added drop wise. The stirring was continued at room temperature for an hour, and the solution was extracted with ethyl acetate. The organic layer was washed with water followed by brine, dried on $\mathrm{MgSO}_{4}$, filtered, and concentrated. The crude product was purified using silica gel column chromatography using methanol:hexane (0-5\%) to afford $33 \mathrm{mg}$ of $\mathbf{3 7 a}$ (Yield: 10\%) as white solid. Product $\mathbf{3 7 b}$ was recrystallized in DCM/n-hexane to provide $264 \mathrm{mg}$ of colorless needles (Yield: 72\%). $14.3 \mathrm{mg}$ of unreacted $o$-carborane was also recovered. 37a: ${ }^{1} \mathrm{H}$ NMR $(500$ $\left.\mathrm{MHz}_{\mathrm{CDCl}}\right): \delta=4.27(\mathrm{~s}, 1 \mathrm{H}), 3.98(\mathrm{~s}, 1 \mathrm{H}), 3.06-1.48(\mathrm{~m}, 10 \mathrm{H}, \mathrm{B}-\mathrm{H}) .{ }^{13} \mathrm{C} \mathrm{NMR}(125.8 \mathrm{MHz}$ $\left.\mathrm{CDCl}_{3}\right): \delta=98.34,62.98 .37 \mathrm{~b}:{ }^{1} \mathrm{H} \mathrm{NMR}\left(500 \mathrm{MHz}, \mathrm{CDCl}_{3}\right): \delta=3.88(\mathrm{~s}, \mathrm{br}, 2 \mathrm{H}), 2.94-1.32(\mathrm{~m}$, 10H, B-H). ${ }^{13} \mathrm{C}$ NMR (125.8 MHz, $\left.\mathrm{CDCl}_{3}\right): \delta=100.87$.

\section{1-(hydroxymethyl)-1,2-dicarbadodecaborane (37c) \& bis-(hydroxymethyl)-1,2-}

dicarbadodecaborane (37d). ${ }^{37}$ In a $50 \mathrm{~mL}$ 2-neck round bottom flask, $o$-carborane $(2.00 \mathrm{~g}$, $13.9 \mathrm{mmol})$ was dissolved in anhydrous THF $(12 \mathrm{~mL})$. The solution was cooled to $0{ }^{\circ} \mathrm{C}$ in an ice bath while stirring, and 2.5 $\mathrm{M} n$-butyllithium in hexane $(5.85 \mathrm{~mL}, 14.6 \mathrm{mmol})$ was added drop wise. The reaction mixture was allowed to stir for 30 minutes while reaching ambient temperature. It was then cooled to $0{ }^{\circ} \mathrm{C}$ again and a solution of paraformaldehyde $(4.16 \mathrm{~g}, 139$ mmol) in anhydrous THF (15 ml) was added drop wise. The resulting suspension was refluxed at $60{ }^{\circ} \mathrm{C}$ for 2 hours and then quenched with $20 \mathrm{~mL}$ of water. The reaction mixture was extracted with diethyl ether. The aqueous layer was extracted with additional diethyl ether. The combined organic extracts were dried over $\mathrm{MgSO}_{4}$, filtered, and concentrated, and purified using silica gel column chromatography using a gradient of EtOAc:hexane (0-20\%) to afford $1.60 \mathrm{~g}$ of $\mathbf{3 7} \mathbf{c}$ as a white powder (Yield: 66\%). $0.65 \mathrm{~g}$ of $\mathbf{3 7 d}$ as white powder (Yield: $44 \%$ ) was also recovered. 
37c: ${ }^{1} \mathrm{H}$ NMR $\left(500 \mathrm{MHz}, \mathrm{CDCl}_{3}\right): \delta=4.09(\mathrm{~d}, J 6.5,2 \mathrm{H}), 3.90(\mathrm{~s}, 1 \mathrm{H}), 2.10(\mathrm{t}, J$ 6.5, 2H), 2.86$1.6(\mathrm{~m}, 10 \mathrm{H}, \mathrm{B}-\mathrm{H}) .{ }^{13} \mathrm{C}$ NMR $\left(125.8 \mathrm{MHz}, \mathrm{CDCl}_{3}\right): \delta=75.12,65.39,57.90 .37 \mathrm{~d}:{ }^{1} \mathrm{H}$ NMR $(500$ $\left.\mathrm{MHz}, \mathrm{CDCl}_{3}\right): \delta=4.23(\mathrm{~d}, J 7.0,4 \mathrm{H}), 2.86(\mathrm{t}, J 7.0,2 \mathrm{H}), 2.88-1.73(\mathrm{~m}, 10 \mathrm{H}, \mathrm{B}-\mathrm{H}) .{ }^{13} \mathrm{C}$ NMR $\left(125.8 \mathrm{MHz}, \mathrm{CDCl}_{3}\right): \delta=78.48,64.83$.

\section{1-(hydroxypropyl)-1,2-dicarbadodecaborane (37e) \& bis-(hydroxypropyl)-1,2-}

dicarbadodecaborane (37f). ${ }^{89}$ In a $500 \mathrm{~mL} 3$-neck round bottom flask, $o$-carborane (11.83 $\mathrm{g}$, $82.00 \mathrm{mmol})$ was dissolved in anhydrous THF $(200 \mathrm{~mL})$. The solution was cooled to $0{ }^{\circ} \mathrm{C}$ in an ice bath while stirring, and 2.4 $\mathrm{M}$-butyllithium in hexane $(75.20 \mathrm{~mL}, 180.5 \mathrm{mmol})$ was added over a fifteen minute period. The reaction mixture was allowed to stir for two hours while reaching ambient temperature. It was then cooled to $0{ }^{\circ} \mathrm{C}$ again and oxetane $(11.20 \mathrm{~mL}, 172.2$ mmol) was added using an addition funnel over a fifteen minute period. The resulting suspension was allowed to stir overnight while slowly reaching ambient temperature. Reaction was washed with saturated solution of ammonium chloride $(3 \times 200 \mathrm{~mL})$, followed by brine $(200 \mathrm{~mL})$. The aqueous layer was extracted once with EtOAc and dried on $\mathrm{MgSO}_{4}$, filtered, and concentrated under vacuum. The resulting oil was dissolved in warm chloroform and the crude product was collected as white crystals. The crude solid was purified using silica gel column chromatography using a gradient of 2-propanol:hexane (0-60\%) to afford a small amount of 37e as well as 16.80 g of $\mathbf{3 7 f}$ (Yield: $78 \%$ ), both as a white solids. 37e: ${ }^{1} \mathrm{H}$ NMR $\left(500 \mathrm{MHz}, \mathrm{CDCl}_{3}\right): \delta=3.63(\mathrm{t}, J$ 6.0, 2H), $3.59(\mathrm{~s}, \mathrm{br}, 1 \mathrm{H}), 2.36-2.33(\mathrm{~m}, 2 \mathrm{H}), 2.06(\mathrm{~s}, 1 \mathrm{H}), 1.76-1.72(\mathrm{~m}, 2 \mathrm{H}), 2.63-1.70(\mathrm{~m}, 10 \mathrm{H}$, B-H). ${ }^{13} \mathrm{C} \mathrm{NMR}\left(125.8 \mathrm{MHz}, \mathrm{CDCl}_{3}\right): \delta=75.32,61.73,61.65,35.15,32.30$. 37f: ${ }^{1} \mathrm{H}$ NMR $(500$ MHz, acetone- $\left.\mathrm{d}_{6}\right): \delta=3.73(\mathrm{~s}, \mathrm{br}, 2 \mathrm{H}), 3.58(\mathrm{t}, J 5.8,4 \mathrm{H}), 2.45(\mathrm{t}, J 8.5,4 \mathrm{H}), 1.8-1.75(\mathrm{~m}, 4 \mathrm{H})$, 3.0-1.5 (m, 10H, B-H). ${ }^{13} \mathrm{C}$ NMR (125.8 MHz, acetone-d 6$): \delta=81.73,61.16,33.78,32.42$. 
${ }^{11} \mathrm{~B}\left\{{ }^{1} \mathrm{H}\right\}(\mathrm{dc}) \mathrm{NMR}\left(160 \mathrm{MHz}\right.$, ether): $\delta=-3.7,10.2$. HRMS (neg.): calcd. for $\mathrm{C}_{8} \mathrm{H}_{24} \mathrm{~B}_{10} \mathrm{O}[\mathrm{M}-\mathrm{H}]^{-}$ 259.271, found: 259.271 .

\section{1-(hydroxy)-1,7-dicarbadodecaborane (38a) and bis-(hydroxy)-1,7-}

dicarbadodecaborane (38b). ${ }^{87}$ Synthesis was similar to 37a and 37b. For 38a, $m$-carborane (230 mg, $1.60 \mathrm{mmol}), 2.5 \mathrm{M} \mathrm{n}$-BuLi in n-hexane (0.67 mL, $1.7 \mathrm{mmol})$, and neat trimethyl borate (0.22 mL, $2 \mathrm{mmol}$ ) were used to afford $232 \mathrm{mg}$ of white solid (Yield: $91 \%$ ), and for 38b, mcarborane (200 mg, $1.39 \mathrm{mmol}), 2.5 \mathrm{M} \mathrm{n}$-BuLi in n-hexane (1.16 mL, $2.91 \mathrm{mmol})$, and neat trimethyl borate $(0.39 \mathrm{~mL}, 3.5 \mathrm{mmol})$ were used to afford $230 \mathrm{mg}$ of white solid (Yield: $94 \%)$.

38a: ${ }^{1} \mathrm{H}$ NMR (500 MHz, $\left.\mathrm{CDCl}_{3}\right): \delta=3.16$ (s, br, $\left.1 \mathrm{H}\right), 2.84$ (s, br, 1H), 3.50-1.53 (m, 10H, B-H). ${ }^{13} \mathrm{C} \mathrm{NMR}\left(125.8 \mathrm{MHz}, \mathrm{CDCl}_{3}\right): \delta=101.75,51.96 . \mathbf{3 8 b}:{ }^{1} \mathrm{H} \mathrm{NMR}\left(500 \mathrm{MHz}\right.$, acetone- $\left.\mathrm{d}_{6}\right): \delta=$ 7.59 (s, D $2 \mathrm{O}$ exchangeable, 2H), 2.94-1.32 (m, 10H, B-H). ${ }^{13} \mathrm{C}$ NMR (125.8 MHz, $\left.\mathrm{CDCl}_{3}: \mathrm{MeOD}\right): \delta=99.03$.

\section{1-(hydroxymethyl)-1,7-dicarbadodecaborane (38c) \& bis-(hydroxymethyl)-1,7-}

dicarbadodecaborane (38d). ${ }^{88}$ In a $250 \mathrm{~mL}$ 3-neck round bottom flask, $m$-carborane $(5.00 \mathrm{~g}$, $34.7 \mathrm{mmol})$ was dissolved in 2:1 mixture of anhydrous benzene and $\mathrm{Et}_{2} \mathrm{O}(60 \mathrm{~mL})$. The solution was cooled to $0^{\circ} \mathrm{C}$ in an ice bath while stirring, and $2.5 \mathrm{M}$-butyllithium in hexane $(15.25 \mathrm{~mL}$, $38.13 \mathrm{mmol}$ ) was added using an automated injection system at the rate of $0.5 \mathrm{ml} / \mathrm{min}$. The reaction mixture was allowed to stir for an hour while reaching ambient temperature. It was then cooled to $0{ }^{\circ} \mathrm{C}$ again and paraformaldehyde $(1.46 \mathrm{~g}, 48.5 \mathrm{mmol})$ was added all at once. The resulting suspension was allowed to stir overnight while slowly reaching ambient temperature. Reaction was quenched with $2 \mathrm{~N} \mathrm{HCl}$ solution $(50 \mathrm{~mL})$ and organic phase was extracted. EtOAc was used to extract the product $(3 \times 50 \mathrm{~mL})$ and all the organic extracts were combined and 
washed with DI water $(80 \mathrm{~mL})$, and brine $(80 \mathrm{~mL})$. Organic extracts were dried on $\mathrm{MgSO}_{4}$, filtered, concentrated, and purified using silica gel column chromatography using a gradient of EtOAc:hexane (20-75\%) to afford $3.59 \mathrm{~g}$ of $\mathbf{3 8 c}$ as a white powder (Yield: $59 \%) .1 .54 \mathrm{~g}$ of $\mathbf{3 8 d}$ as white powder (Yield: $31 \%$ ), and $560 \mathrm{mg}$ of $m$-carborane were also recovered. 38c: ${ }^{1} \mathrm{H}$ NMR (500 MHz, $\left.\mathrm{CDCl}_{3}\right): \delta=3.81(\mathrm{~s}, 2 \mathrm{H}), 2.95(\mathrm{~s}, 1 \mathrm{H}), 1.89(\mathrm{~s}, 1 \mathrm{H}), 2.84-1.73(\mathrm{~m}, 10 \mathrm{H}, \mathrm{B}-\mathrm{H}) .{ }^{13} \mathrm{C}$ $\operatorname{NMR}\left(125.8 \mathrm{MHz}, \mathrm{CDCl}_{3}\right): \delta=65.63,55.21 .{ }^{11} \mathrm{~B}\left\{{ }^{1} \mathrm{H}\right\}(\mathrm{dc}) \mathrm{NMR}\left(96.3 \mathrm{MHz}, \mathrm{CDCl}_{3}\right): \delta=-4.80$, $-6.72,-9.15,-10.79,-11.96,-13.37,-15.97 .38 d:{ }^{1} \mathrm{H}$ NMR (300 MHz, MeOD): $\delta=4.88$ (s, 2H), 3.75 (s, 4H), 3.03-1.44 (m, 10H, B-H). ${ }^{13} \mathrm{C}$ NMR (75.5 MHz, MeOD): $\delta=80.31,66.5 .{ }^{11} \mathrm{~B}\left\{{ }^{1} \mathrm{H}\right\}$ (dc) NMR (96.3 MHz, $\left.\mathrm{CDCl}_{3}\right): \delta=-7.38,-11.93,-14.74$. 


\section{References:}

(1) Fanfrlik, J.; Lepsik, M.; Horinek, D.; Havlas, Z.; Hobza, P. Chemphyschem : a European journal of chemical physics and physical chemistry 2006, 7, 1100.

(2) Samal, B.; Sun, Y.; Stearns, G.; Xie, C.; Suggs, S.; McNiece, I. Molecular and cellular biology 1994, 14, 1431.

(3) Fukuhara, A.; Matsuda, M.; Nishizawa, M.; Segawa, K.; Tanaka, M.; Kishimoto, K.; Matsuki, Y.; Murakami, M.; Ichisaka, T.; Murakami, H.; Watanabe, E.; Takagi, T.; Akiyoshi, M.; Ohtsubo, T.; Kihara, S.; Yamashita, S.; Makishima, M.; Funahashi, T.; Yamanaka, S.; Hiramatsu, R.; Matsuzawa, Y.; Shimomura, I. Science 2005, 307, 426.

(4) Garten, A.; Petzold, S.; Korner, A.; Imai, S.; Kiess, W. Trends in endocrinology and metabolism: TEM 2009, 20, 130.

(5) Shackelford, R. E.; Mayhall, K.; Maxwell, N. M.; Kandil, E.; Coppola, D. Genes \& Cancer 2013, 4, 447.

(6) Fukuhara, A.; Matsuda, M.; Nishizawa, M.; Segawa, K.; Tanaka, M.; Kishimoto, K.; Matsuki, Y.; Murakami, M.; Ichisaka, T.; Murakami, H.; Watanabe, E.; Takagi, T.; Akiyoshi, M.; Ohtsubo, T.; Kihara, S.; Yamashita, S.; Makishima, M.; Funahashi, T.; Yamanaka, S.; Hiramatsu, R.; Matsuzawa, Y.; Shimomura, I. Science 2007, 318, 565.

(7) Sauve, A. A. The Journal of pharmacology and experimental therapeutics 2008, 324, 883.

(8) Revollo, J. R.; Körner, A.; Mills, K. F.; Satoh, A.; Wang, T.; Garten, A.; Dasgupta, B.; Sasaki, Y.; Wolberger, C.; Townsend, R. R.; Milbrandt, J.; Kiess, W.; Imai, S.-i. Cell Metabolism 2007, 6, 363. 
(9) Revollo, J. R.; Grimm, A. A.; Imai, S.-i. Journal of Biological Chemistry 2004, 279, 50754.

(10) Berger, F.; Ramírez-Hernández, M. a. H.; Ziegler, M. Trends in Biochemical Sciences 2004, 29, 111.

(11) Olesen, U. H.; Thougaard, A. V.; Jensen, P. B.; Sehested, M. Molecular Cancer Therapeutics 2010, 9, 1609.

(12) Rongvaux, A.; Shea, R. J.; Mulks, M. H.; Gigot, D.; Urbain, J.; Leo, O.; Andris, F. European Journal of Immunology 2002, 32, 3225.

(13) Kim, M. K.; Lee, J. H.; Kim, H.; Park, S. J.; Kim, S. H.; Kang, G. B.; Lee, Y. S.; Kim, J. B.; Kim, K. K.; Suh, S. W.; Eom, S. H. Journal of molecular biology 2006, 362, 66.

(14) Hasmann, M.; Schemainda, I. Cancer Research 2003, 63, 7436.

(15) Wosikowski, K.; Mattern, K.; Schemainda, I.; Hasmann, M.; Rattel, B.; Löser, R. Cancer Research 2002, 62, 1057.

(16) Khan, J. A.; Forouhar, F.; Tao, X.; Tong, L. Expert Opinion on Therapeutic Targets 2007, 11, 695.

(17) Zheng, X.; Bauer, P.; Baumeister, T.; Buckmelter, A. J.; Caligiuri, M.; Clodfelter, K. H.; Han, B.; Ho, Y.-C.; Kley, N.; Lin, J.; Reynolds, D. J.; Sharma, G.; Smith, C. C.; Wang, Z.; Dragovich, P. S.; Gunzner-Toste, J.; Liederer, B. M.; Ly, J.; O’Brien, T.; Oh, A.; Wang, L.; Wang, W.; Xiao, Y.; Zak, M.; Zhao, G.; Yuen, P.-w.; Bair, K. W. Journal of medicinal chemistry 2013, 56, 6413.

(18) Wang, T.; Zhang, X.; Bheda, P.; Revollo, J. R.; Imai, S.-i.; Wolberger, C. Nature structural \& molecular biology 2006, 13, 661.

(19) Khan, J. A.; Tao, X.; Tong, L. Nature structural \& molecular biology 2006, 13, 582. 
(20) Khan, J. A.; Tao, X.; Tong, L. Nature structural \& molecular biology 2006, 13, 582.

(21) Oh, A.; Ho, Y.-C.; Zak, M.; Liu, Y.; Chen, X.; Yuen, P.-w.; Zheng, X.; Liu, Y.;

Dragovich, P. S.; Wang, W. ChemBioChem 2014, 15, 1121.

(22) Bregadze, V. I. Chemical reviews 1992, 92, 209.

(23) Leites, L. A. Chemical reviews 1992, 92, 279.

(24) Lee, M. W., Jr.; Sevryugina, Y. V.; Khan, A.; Ye, S. Q. Journal of medicinal chemistry 2012, 55, 7290 .

(25) Valliant, J. F.; Guenther, K. J.; King, A. S.; Morel, P.; Schaffer, P.; Sogbein, O. O.;

Stephenson, K. A. Coordination Chemistry Reviews 2002, 232, 173.

(26) Jia, S. H.; Li, Y.; Parodo, J.; Kapus, A.; Fan, L.; Rotstein, O. D.; Marshall, J. C. The Journal of Clinical Investigation 2004, 113, 1318.

(27) Roberts, K. J.; Cross, A.; Vasieva, O.; Moots, R. J.; Edwards, S. W. Journal of Leukocyte Biology 2013, 94, 481.

(28) Villiers, A. C. R. Acad. Sci. 1891, 112, 536.

(29) van de Manakker, F.; Vermonden, T.; van Nostrum, C. F.; Hennink, W. E. Biomacromolecules 2009, 10, 3157.

(30) Schmid, G. Tibtech 1989, 7, 244.

(31) Davis, M. E.; Brewster, M. E. Nat. Rev. Drug Discovery 2004, 3, 1023.

(32) Brewster, M. E.; Loftsson, T. Adv. Drug Delivery Rev. 2007, 59, 645.

(33) Loftsson, T.; Duchene, D. Int. J. Pharm. 2007, 329, 1.

(34) Cal, K.; Centkowska, K. Eur. J. Pharm. Biopharm. 2008, 68, 467.

(35) Stella, V. J.; Rao, V. M.; Zannou, E. A.; Zia, V. Advanced drug delivery reviews 1999, 36,3 . 
(36) Frixa, C.; Scobie, M.; Black, S. J.; Thompson, A. S.; Threadgill, M. D. Chemical Communications 2002, 2876.

(37) Ohta, K.; Konno, S.; Endo, Y. Tetrahedron letters 2008, 49, 6525.

(38) Ohta, K.; Konno, S.; Endo, Y. Chem. Pharm. Bull. 2009, 57, 307.

(39) Harada, A.; Takashima, Y.; Yamaguchi, H. Chem. Soc. Rev. 2009, 38, 875.

(40) Vaitkus, R.; Sjöberg, S. Journal of Inclusion Phenomena and Macrocyclic Chemistry 2011, 69, 393.

(41) Stella, V. J.; He, Q. Toxicol. Pathol. 2008, 36, 30.

(42) Hufton, S. E.; Moerkerk, P. T.; Brandwijk, R.; de Bruïne, A. P.; Arends, J.-W.; Hoogenboom, H. R. FEBS Letters 1999, 463, 77.

(43) van Beijnum, J. R.; Moerkerk, P. T. M.; Gerbers, A. J.; de Bruïne, A. P.; Arends, J.-W.; Hoogenboom, H. R.; Hufton, S. E. International Journal of Cancer 2002, 101, 118.

(44) Nahimana, A.; Attinger, A.; Aubry, D.; Greaney, P.; Ireson, C.; Thougaard, A. Blood 2009, 113, 3276 .

(45) Reddy, P. S.; Umesh, S.; Thota, B.; Tandon, A.; Pandey, P.; Hegde, A. S.;

Balasubramaniam, A.; Chandramouli, B. A.; Santosh, V.; S Rao, M. R.; Kondaiah, P.; Somasundaram, K. Cancer Biology \& Therapy 2008, 7, 663.

(46) Nakajima, T. E.; Yamada, Y.; Hamano, T.; Furuta, K.; Gotoda, T.; Katai, H.; Kato, K.; Hamaguchi, T.; Shimada, Y. Journal of gastroenterology 2009, 44, 685.

(47) Nakajima, T. E.; Yamada, Y.; Hamano, T.; Furuta, K.; Matsuda, T.; Fujita, S.; Kato, K.; Hamaguchi, T.; Shimada, Y. Cancer Science 2010, 101, 1286. 
(48) Yang, H.; Yang, T.; Baur, J. A.; Perez, E.; Matsui, T.; Carmona, J. J.; Lamming,

Dudley W.; Souza-Pinto, N. C.; Bohr, V. A.; Rosenzweig, A.; de Cabo, R.; Sauve, Anthony A.; Sinclair, D. A. Cell 2007, 130, 1095.

(49) Patel, S. T.; Mistry, T.; Brown, J. E. P.; Digby, J. E.; Adya, R.; Desai, K. M.; Randeva, H. S. Peptides 2010, 31, 51.

(50) Bi, T.; Che, X. Cancer Biology \& Therapy 2010, 10, 119.

(51) Muruganandham, M.; Alfieri, A. A.; Matei, C.; Chen, Y.; Sukenick, G.; Schemainda, I.; Hasmann, M.; Saltz, L. B.; Koutcher, J. A. Clinical Cancer Research 2005, 11, 3503.

(52) Holen, K.; Saltz, L. B.; Hollywood, E.; Burk, K.; Hanauske, A. R. Investigational new drugs 2008, 26, 45.

(53) Huang, P.; Lee, M. W., Jr.; Heruth, D. P.; Sokolovsky, I.; Nsumu, M.; Grigoryev, D. N.; Zhang, L. Q.; Ye, S. Q. Thematic Poster Session/Wednesday, May 21/8:15 AM-4:30 PM/Area B (Hall B2-C, Ground Level) San Diego Convention Center 2014.

(54) Mosmann, T. Journal of Immunological Methods 1983, 65, 55.

(55) Siebum, Arjan H. G.; Tsang, Robert K. F.; Steen, Rob van d.; Raap, J.; Lugtenburg, J. European Journal of Organic Chemistry 2004, 2004, 4391.

(56) Pham, T. Q.; Greguric, I.; Liu, X.; Berghofer, P.; Ballantyne, P.; Chapman, J.; Mattner, F.; Dikic, B.; Jackson, T.; Loc, C.; Katsifis, A. Journal of medicinal chemistry 2007, 50, 3561.

(57) Williams, D. B. G.; Lawton, M. The Journal of Organic Chemistry 2010, 75, 8351.

(58) Martin, S. W.; Romine, J. L.; Chen, L.; Mattson, G.; Antal-Zimanyi, I. A.; Poindexter, G. S. Journal of Combinatorial Chemistry 2004, 6, 35. 
(59) Meier, G.; Apelt, J.; Reichert, U.; Graßmann, S.; Ligneau, X.; Elz, S.; Leurquin, F.;

Ganellin, C. R.; Schwartz, J.-C.; Schunack, W.; Stark, H. European Journal of Pharmaceutical Sciences 2001, 13, 249.

(60) Chari, R. V. J.; Miller, M. L.; Widdison, W. C. Angewandte Chemie International Edition 2014, 53, 3796.

(61) Sievers, E. L.; Senter, P. D. Annual Review of Medicine 2013, 64, 15.

(62) Alley, S. C.; Okeley, N. M.; Senter, P. D. Current Opinion in Chemical Biology 2010, 14, 529.

(63) Casi, G.; Neri, D. Journal of Controlled Release 2012, 161, 422.

(64) Hughes, B. Nat Rev Drug Discov 2010, 9, 665.

(65) Krop, I. E.; Beeram, M.; Modi, S.; Jones, S. F.; Holden, S. N.; Yu, W.; Girish, S.;

Tibbitts, J.; Yi, J.-H.; Sliwkowski, M. X.; Jacobson, F.; Lutzker, S. G.; Burris, H. A. Journal of Clinical Oncology 2010, 28, 2698.

(66) LoRusso, P. M.; Weiss, D.; Guardino, E.; Girish, S.; Sliwkowski, M. X. Clinical Cancer Research 2011, 17, 6437.

(67) Gallí, M.; Van Gool, F.; Rongvaux, A.; Andris, F.; Leo, O. Cancer Research 2010, 70, 8. (68) Lee, Y.-C.; Yang, Y.-H.; Su, J.-H.; Chang, H.-L.; Hou, M.-F.; Yuan, S.-S. F. Cancer Epidemiology Biomarkers \& Prevention 2011, 20, 1892.

(69) Kato, Y.; Ozawa, S.; Miyamoto, C.; Maehata, Y.; Suzuki, A.; Maeda, T.; Baba, Y. Cancer Cell International 2013, 13, 1.

(70) Binderup, E.; Bjorkling, F.; Hjarnaa, P. V.; Latini, S.; Baltzer, B.; Carlsen, M.; Binderup, L. Bioorganic \& medicinal chemistry letters 2005, 15, 2491.

(71) Richter, D.; Croft, P. G. Biochemical Journal 1942, 36, 746. 
(72) O'Mahony, A. M.; Ogier, J.; Desgranges, S.; Cryan, J. F.; Darcy, R.; O'Driscoll, C. M. Organic \& biomolecular chemistry 2012, 10, 4954.

(73) Issa, F.; Kassiou, M.; Rendina, L. M. Chemical reviews 2011, 111, 5701.

(74) Bonechi, C.; Ristori, S.; Martini, S.; Panza, L.; Martini, G.; Rossi, C.; Donati, A. Biophysical Chemistry 2007, 125, 320.

(75) Calabrese, G.; Nesnas, J. J.; Barbu, E.; Fatouros, D.; Tsibouklis, J. Drug Discovery Today 2012, 17, 153.

(76) Giovenzana, G. B.; Lay, L.; Monti, D.; Palmisano, G.; Panza, L. Tetrahedron 1999, 55, 14123.

(77) Benhabbour, S. R.; Alex, A. In Polymers for Biomedical Applications; American Chemical Society: 2008; Vol. 977, p 238.

(78) Hosmane, N. S.; Maguire, J. A.; Zhu, Y.; Takagaki, M. In Boron and Gadolinium Neutron Capture Therapy for Cancer Treatment 2012, p 7.

(79) Neirynck, P.; Schimer, J.; Jonkheijm, P.; Milroy, L. G.; Cigler, P.; Brunsveld, L. Journal of Materials Chemistry B 2015, 3, 539.

(80) Selvidge, L. A.; Eftink, M. R. Analytical Biochemistry 1986, 154, 400.

(81) Harada, A.; Takahashi, S. Journal of the Chemical Society, Chemical Communications $1988,1352$.

(82) Pinjari, R. V.; Khedkar, J. K.; Gejji, S. P. Journal of Inclusion Phenomena and Macrocyclic Chemistry 2010, 66, 371.

(83) Pinjari, R. V.; Joshi, K. A.; Gejji, S. P. J. Phys. Chem. A 2006, 110, 13073.

(84) Scholz, F.; Nothofer, H.-G.; Wessels, J. M.; Nelles, G.; von Wrochem, F.; Roy, S.; Chen, X.; Michl, J. The Journal of Physical Chemistry C 2011, 115, 22998. 
(85) Zhang, M.; Zukoski, C. F. Langmuir : the ACS journal of surfaces and colloids 2014, 30, 7540.

(86) Fielding, L. Tetrahedron 2000, 56, 6151.

(87) Ohta, K.; Goto, T.; Yamazaki, H.; Pichierri, F.; Endo, Y. Inorg. Chem. 2007, 46, 3966.

(88) Goto, T.; Ohta, K.; Suzuki, T.; Ohta, S.; Endo, Y. Bioorganic \& medicinal chemistry $\mathbf{2 0 0 5}, 13,6414$.

(89) Naeslund, C.; Ghirmai, S.; Sjöberg, S. Tetrahedron 2005, 61, 1181.

(90) Okubo, T.; Kuroda, M. Macromolecules 1989, 22, 3936.

(91) Tutaj, B.; Kasprzyk, A.; Czapkiewicz, J. Journal of Inclusion Phenomena and Macrocyclic Chemistry 2003, 47, 133.

(92) Lu, Z.; Li, Z.; Gu, Z.; Hong, Y.; Li, C.; Ban, X. Fenxi Kexue Xuebao 2013, 29, 201.

(93) Li, W.; Corke, H.; Zhang, L. Starch - Stärke 1996, 48, 382.

(94) Cadena, P.; Oliveira, E.; Araújo, A.; Montenegro, M. B. S. M.; Pimentel, M. B.; Lima Filho, J.; Silva, V. Lipids 2009, 44, 1063. 


\section{VITA}

Keivan Sadrerafi is an Iranian, born in the city of Pune, India. At the time of his birth, his parents where pursuing higher education overseas. They returned to the city of Rasht, Iran when he was two years old. His family moved to the capital city of Tehran, Iran where he attended grade school. While he was attending middle school in Tehran, his family moved once more. They moved to the United States, where he finished middle school and went to Belleville High SchoolEast. Wanting to stay close to his family, he applied to the Sothern Illinois UniversityEdwardsville, where he received both his B.A., and M.S. degrees in analytical chemistry under the supervision of Professor Sadegh Khazaeli. He then joined the department of chemistry at University of Missouri-Columbia to pursue a Ph.D. in medicinal chemistry, under guidance and mentorship of Professor Mark W. Lee Jr. His graduate research involved designing, synthesis, and characterization of cancer targeted Nampt inhibitors. 